\title{
Insights into Antibody-Mediated Alphavirus Immunity and Vaccine Development Landscape
}

\author{
Anthony Torres-Ruesta ${ }^{1,2,+}$ (D), Rhonda Sin-Ling Chee ${ }^{1,+}$ and Lisa F.P. $\mathrm{Ng}^{1,2,3, *}$ \\ 1 A*STAR Infectious Diseases Labs (A*STAR ID Labs), Agency for Science, Technology and Research (A*STAR), \\ Singapore 138648, Singapore; anthony_torres@IDLabs.a-star.edu.sg (A.T.-R.); \\ rhonda_chee@IDLabs.a-star.edu.sg (R.S.-L.C.) \\ 2 Department of Biochemistry, Yong Loo Lin School of Medicine, National University of Singapore, \\ Singapore 117596, Singapore \\ 3 Institute of Infection, Veterinary and Ecological Sciences, University of Liverpool, Liverpool L69 3BX, UK \\ * Correspondence: Lisa_Ng@IDLabs.a-star.edu.sg; Tel.: +65-6407-0028 \\ + Both authors contributed equally to this work.
}

check for updates

Citation: Torres-Ruesta, A.; Chee, R.S.-L.; $\mathrm{Ng}$, L.F.P. Insights into Antibody-Mediated Alphavirus Immunity and Vaccine Development Landscape. Microorganisms 2021, 9, 899. https://doi.org/10.3390/ microorganisms 9050899

Academic Editor: Kevin K. Arien

Received: 19 March 2021

Accepted: 16 April 2021

Published: 22 April 2021

Publisher's Note: MDPI stays neutral with regard to jurisdictional claims in published maps and institutional affiliations.

Copyright: (c) 2021 by the authors. Licensee MDPI, Basel, Switzerland. This article is an open access article distributed under the terms and conditions of the Creative Commons Attribution (CC BY) license (https:// creativecommons.org/licenses/by/ $4.0 /)$.

\begin{abstract}
Alphaviruses are mosquito-borne pathogens distributed worldwide in tropical and temperate areas causing a wide range of symptoms ranging from inflammatory arthritis-like manifestations to the induction of encephalitis in humans. Historically, large outbreaks in susceptible populations have been recorded followed by the development of protective long-lasting antibody responses suggesting a potential advantageous role for a vaccine. Although the current understanding of alphavirus antibody-mediated immunity has been mainly gathered in natural and experimental settings of chikungunya virus (CHIKV) infection, little is known about the humoral responses triggered by other emerging alphaviruses. This knowledge is needed to improve serology-based diagnostic tests and the development of highly effective cross-protective vaccines. Here, we review the role of antibody-mediated immunity upon arthritogenic and neurotropic alphavirus infections, and the current research efforts for the development of vaccines as a tool to control future alphavirus outbreaks.
\end{abstract}

Keywords: alphavirus; antibody; immunity; alphavirus vaccine

\section{Introduction}

Mosquito-borne alphaviruses are Group IV viruses that belong to the family Togaviridae [1]. They are enveloped, positive-sense, single-stranded RNA viruses with a size of $\approx 70 \mathrm{~nm}$ bearing a $\approx 11.7$ kilobases genome which encodes four non-structural proteins (nsP1, nsP2, nsP3 and nsP4) that serve as the virus' replication machinery, and five structural proteins (capsid, E3, E2, 6K and E1) that participate in the envelope assembly process [1]. Clinically, alphavirus infections in humans results in the development of viremia followed by an onset of febrile symptoms [2]. The development of inflammatory conditions compromising joints and muscle tissues has been associated to arthritogenic alphaviruses such as chikungunya virus (CHIKV), O'nyong nyong virus (ONNV), Mayaro virus (MAYV), Ross River virus (RRV), Semliki Forest virus (SFV) and Sindbis virus (SINV) with records of persistent polyarthralgia in a fraction of patients. Conversely, neurotropic alphaviruses such as Eastern Equine Encephalitis virus (EEEV), Western Equine Encephalitis virus (WEEV) and Venezuelan Equine Encephalitis virus (EEEV) have been linked to the induction of lethal encephalitis in humans and animals [3,4].

Historically, alphaviruses have a proven record of causing massive outbreaks in susceptible populations [5-8]. Additionally, the appearance of mutations favoring their ecological fit to new vectors has fueled alphavirus propagation worldwide [9,10]. A clear example of their potential as a health threat is the re-emergence of CHIKV in 2004 after a hiatus of more than 50 years since its discovery [5]. More recently, tropical emerging alphaviruses such as ONNV and MAYV are believed to have the potential to become 
future major epidemics [11-13]. This is due, in part, to the lack of robust diagnostic tests to differentiate alphavirus infections from other febrile tropical diseases and the absence of continuous epidemiological surveillance masking their real potential for spread beyond endemic areas [14-16].

Although alphavirus infections are generally not life threating the economic and social costs incurred during outbreaks are thought to be high [17-19]. Moreover, the lack of approved treatments leaves management of alphavirus infections to supportive care [20]. Interestingly, a body of work suggests that the alphavirus infection triggers potent humoral responses in exposed populations which seem to confer protection against re-infection [21]. Therefore, a better understanding of the antibody responses against alphaviruses is crucial for the development of vaccines, which would represent a big advantage in the control of alphavirus infections.

\section{Antibody-Mediated Alphavirus Immunity}

\subsection{Virus-Specific Antibody Kinetics Upon Natural Infection with Alphaviruses}

The current knowledge on the role of antibody-mediated immunity upon viral infection has been gathered from cohort studies following major alphavirus outbreaks. Serological surveys following CHIKV re-emergence in 2004 reported the quick development of IgM responses between five to seven days post-illness onset (PIO) [22,23]. IgM is generally detectable for up to three months post-infection [24-26]. However, long-lasting IgM has been often reported in patients with long-term $\mathrm{CHIKV-induced} \mathrm{polyarthralgia,} \mathrm{which}$ might indicate a constant antigenic stimulation due to viral persistence [27]. After the initial detection of IgM antibodies, IgG seroconversion reportedly occurs between 4 to 10 days PIO taking over as the main immunoglobulin detected in serum [22,28]. Notably, IgG3 antibodies become the dominant IgG subtype produced upon infection and have been associated to efficient viral clearance and protection against chronic CHIKV symptoms [23]. Importantly, IgG responses persist for several years and might be potentially lifelong [29].

ONNV and MAYV, both closely-related to CHIKV, are re-emerging arthritogenic alphaviruses believed to be confined to sub-Saharan Africa, and Latin America, respectively $[6,11,12,15]$. Following the largest ONNV outbreak in Uganda involving more than two million cases between 1959-1962 [6,30], the induction of potent neutralizing antibodies was described [31]. The first study cohort that evaluated IgM kinetics upon ONNV infection in Uganda [32] reported the appearance of IgM antibodies during the second week PIO which remained elevated for two months. In contrast, reports from imported ONNV cases in Europe described detectable IgM levels as early as five days PIO [33,34]. ONNV-specific IgG levels are increased in serum after the third week and remain high beyond two months PIO $[11,34]$. However, whether IgG responses are long-lasting remains unknown. Similarly, endemic MAYV infections are characterized by the early appearance of IgM antibodies (3-8 days PIO) that might last for one to three months $[35,36]$. IgG becomes detectable around 4-10 days PIO [35] and remains elevated after 6-12 months [37,38]. Interestingly, unlike ONNV and CHIKV infections, persistent arthralgia has been reported in more than half of MAYV-infected individuals and although MAYV-specific antibody responses are critical for disease resolution it is seemingly insufficient to protect patients from the development of chronic joint manifestations [39].

Other alphaviruses linked to continuous small outbreaks associated with arthritic manifestations in human populations are RRV and SINV. RRV is endemic to Australia and is responsible for approximately 4000-5000 cases annually [40]. Typically, antibody kinetics upon RRV infection are characterized by the development of IgM titers between 7-10 days PIO, peaking at two to three weeks and lasting for 1-3 months [41,42]. IgM response rapidly declines after three weeks PIO as IgG becomes dominant [42,43]. Interestingly, IgM persistence has been reported in some RRV cohorts [41]. In one study [44], 19/116 (16.4\%) of participants had detectable IgM levels that lasted between seven months to eight years PIO. Likewise, less prevalent SINV has also been linked to the development of persistent virus-specific IgM levels. Although, generally, the antibody response upon SINV infection 
generates IgM antibodies after 6-9 days PIO and IgG antibodies after 9-14 days, some reports described the presence of detectable IgM levels up to four years suggesting active viral replication [45-47]. The clinical relevance of persistent IgM levels following RRV and SINV infection is yet to be determined.

Neurotropic alphaviruses such as EEEV, WEEV and VEEV cause sporadic cases of human encephalitis in the Americas [4]. While the natural reservoirs for these viruses are primarily birds and equines, humans are susceptible to infection when the enzootic cycle of transmission leaks into mosquito populations with a wide range of hosts [48]. Given that human cases are rare, there is a lack of information regarding the development of antibody responses upon natural infections by neurotropic alphaviruses. In a paired serology study [49], virus-specific antibody responses were profiled in a cohort of $20 \mathrm{EEEV}$ and $17 \mathrm{WEEV}$-infected patients. IgM antibodies were observed as early as 1 PIO, peaking after 1-2 weeks and remaining detectable for up to three months. In contrast, IgG responses appeared during the second week PIO and remained elevated until the end of the follow-up period.

\subsection{Experimental Evidence of the Role of Antibodies in Alphavirus Immunity}

To better understand the role of antibody-mediated immunity upon alphavirus infection, several animal models have been used allowing the detailed examination of the cellular compartments responsible for the initiation of humoral immunity. The role of $\mathrm{B}$ cells in alphavirus immunity has been described in experimental CHIKV infections. Inoculation of $\mu \mathrm{MT}$ mice (lacking mature B cells) with CHIKV resulted in higher viremia that persisted up to 402 days post-infection (DPI). In contrast, infected wild type (WT) mice were able to control the virus during the second week post-inoculation [50]. Similar findings were reported in other studies, where mouse strains lacking B cells ( $\mu \mathrm{MT}$, Rag1, Rag2/IL2rg, NRG) infected with CHIKV displayed increased and persistent viremia for up to 515 DPI [51,52].

B cells also play an important role in alphavirus-induced encephalitis. Although SINV infections in humans are known to cause arthritic manifestations, SINV has been frequently used as a model of alphavirus-induced encephalomyelitis in adult immunocompetent mice given the virus ability to infect neurons [53]. Intracerebral inoculation of SINV in $\mu M T$ and severe combined immunodeficiency (SCID) mice resulted in defective viral clearance from the brain, brain stem and lumbar spinal cord, virus persistence and recrudescence compared to WT mice [54]. The individual contributions of IgM and IgG antibodies to SINV clearance from brain tissues were assessed in another study [55] where infection in $\mathrm{AID}^{-/-}$(unable to produce $\mathrm{IgG}$ ), $\operatorname{sIgM}^{-/-}$(unable to produce $\mathrm{IgM}$ ) and $\mathrm{AID}^{-/-}$ $\mathrm{sIgM}^{-/-}$double-knockout mice resulted only in $\mathrm{AID}^{-/-} \operatorname{sIgM}^{-/-}$being unable to control infection efficiently suggesting that either IgM or IgG antibodies are sufficient to clear SINV from the central nervous system (CNS). Similar results were obtained in SFV models of encephalitis where infection of $\mu \mathrm{MT}$ [56], SCID [57] and nude mice with impaired antibody switching [58] led to viral persistence.

Infiltrating virus-specific B cells were observed in infected tissues in a murine model of SINV-induced encephalitis [59,60]. Following intracranial virus inoculation, expansion of IgM-secreting plasmablasts was reported in the cervical lymph nodes. Infiltration of CD19+ B cells occurred between 3-7 DPI and coincided with the starting of viral clearance. During the clearance of persistent viral RNA (from 8-80 DPI), the accumulation of SINV-specific IgG and IgA-secreting B cells was observed being associated with increased SINV antibody titers over time [60]. In a subsequent study, it was reported that the brain microenvironment during the early stages of SINV infection facilitates the migration, differentiation, expansion and long term survival of SINV-specific B cells [59].

Follicular helper $\mathrm{T}$ cells $\left(\mathrm{T}_{\mathrm{FH}}\right)$ are a subset of $\mathrm{CD} 4 \mathrm{~T}$ cells involved in the activation of B lymphocytes and the establishment of robust antibody responses following antigen stimulation. $\mathrm{T}_{\mathrm{FH}}$ promotes $\mathrm{B}$ cell differentiation, isotype switching and affinity maturation. In experimental CHIKV infections, the use of CD4-deficient mice ruled out the role of 
$\mathrm{CD} 4 \mathrm{~T}$ cells in viral clearance from infected tissues [61]. However, one study demonstrated impaired IgM and IgG (IgG2c, IgG1, and IgG2b) production in mice lacking CD4 $\mathrm{T}$ cells following CHIKV inoculation [62]. Albeit reduced virus-specific antibody levels, the neutralizing capacity of sera from virus-infected CD4-deficient mice was marginally affected [62]. Likewise, another study showed similar results upon CHIKV inoculation of $\mathrm{MHCII}^{\Delta / \Delta}$ mice (defective of $\mathrm{T}_{\mathrm{FH}}$ ) [51]. $\mathrm{MHCII}^{\Delta / \Delta}$ animals were unable to generate IgG1 antibodies and produced $\approx 100$ fold lower IgG2c levels than WT controls. Nonetheless, $\mathrm{MHCII}^{\Delta / \Delta}$ mice were still able to control virus infection [51]. The generation of virus-specific neutralizing antibodies in $\mathrm{MHCII}^{\Delta / \Delta}$ mice suggests a T-cell independent $\mathrm{B}$ cell activation characterized by the inability to generate memory B cells. Whether CHIKV-specific antibody responses in mice lacking CD4 $\mathrm{T}$ cells are long-lasting remains to be elucidated.

\subsection{Viral Antigenic Regions Targeted by Neutralizing Antibodies}

The notion of targeting humoral immunity as a therapy against alphavirus infection has been investigated since the late 1930s following the isolation of EEEV, WEEV and VEEV. In a series of seminal studies involving immunization of guinea pigs [63-66], the subcutaneous inoculation of live EEEV and WEEV strains protected guinea pigs from lethal intracranial infection [63]. Additionally, it was observed that immunization with formalin-inactivated virus strains induced the production of neutralizing antibodies at a comparable level than animals immunized with live viruses [64-66]. Subsequent studies reported that passive transfer of hyperimmune rabbit serum protected mice, guinea pigs and rabbits from WEEV infection [66,67]. Similarly, passive serum transfer was shown to be effective at protecting mice from the development of neurological complications upon infection with a neuroadapted strain of SINV [68,69]. Comparable observations were reported in experimental infection models of VEEV [70], CHIKV [71,72], RRV [73] and SFV [74].

The first attempts in identifying the exact structural regions, recognized by most neutralizing antibodies produced upon infection, were conducted in experimental infection models of alphavirus encephalitis. Structurally, the envelope of an alphavirus virion has a $\mathrm{T}=4$ icosahedral symmetry [75]. E1 and E2 are two envelop surface glycoproteins exposed in the viral spike as a heterodimer [75] (Figure 1). It is believed that the E1-E2 heterodimer interacts with host receptors thus mediating viral entry [75]. Additionally, the E1 and E2 glycoproteins were postulated as highly immunogenic regions since their location in the spike facilitates antigenic recognition. In line with this, early works mapped antigenic sites involved in VEEV, SINV and SFV neutralization to the E1 and E2 proteins using competitive binding assays but the exact amino acid sequences were not determined [76-78]. Later, a major antigenic region involving three epitopes important in the neutralization of RRV was identified in the E2 protein (incorporating residues 216, 232 and 234) [79]. Similarly, analysis of antibody escape variants determined important antigenic regions between amino acids 181 and 216 on the E2 protein of SINV [80]. A major neutralization domain was also identified between residues 182-207 for VEEV [81].

Following CHIKV reemergence in 2004 several reports identified major linear antigenic sites in the CHIKV E2 protein that induced the production of potent neutralizing antibodies. Using a CHIKV proteome-wide screening approach, a single linear peptide located at the N-terminus of the E2 glycoprotein, E2EP3, was reported as strongly recognized by convalescent CHIKV patients from different cohorts [23]. Furthermore, experimental CHIKV infection in mice and non-human primates (NHP) validated E2EP3 as an immunodominant linear epitope inducing potent neutralizing antibodies [23,62,82]. Interestingly, mice immunization with E2EP3 alone reduced joint swelling and viremia upon CHIKV challenge [23]. In another study focusing on human antibody responses to SINV in cohort from Finland, 6 linear epitopes, located in the capsid, E2, E1 and PE2 (uncleaved E3-E2) proteins, were reported [83]. Three of these epitopes were located to the glycoprotein spike complex between the residues 209-226 of E1 (E1-P5), 273-290 (E2-P3) and 308-325 (E2-P4) 
of E2 [83]. Interestingly, the E2EP3 equivalent of SINV remained non-reactive suggesting that antibody kinetics against linear E2EP3 between populations exposed to CHIKV and SINV might differ [83].
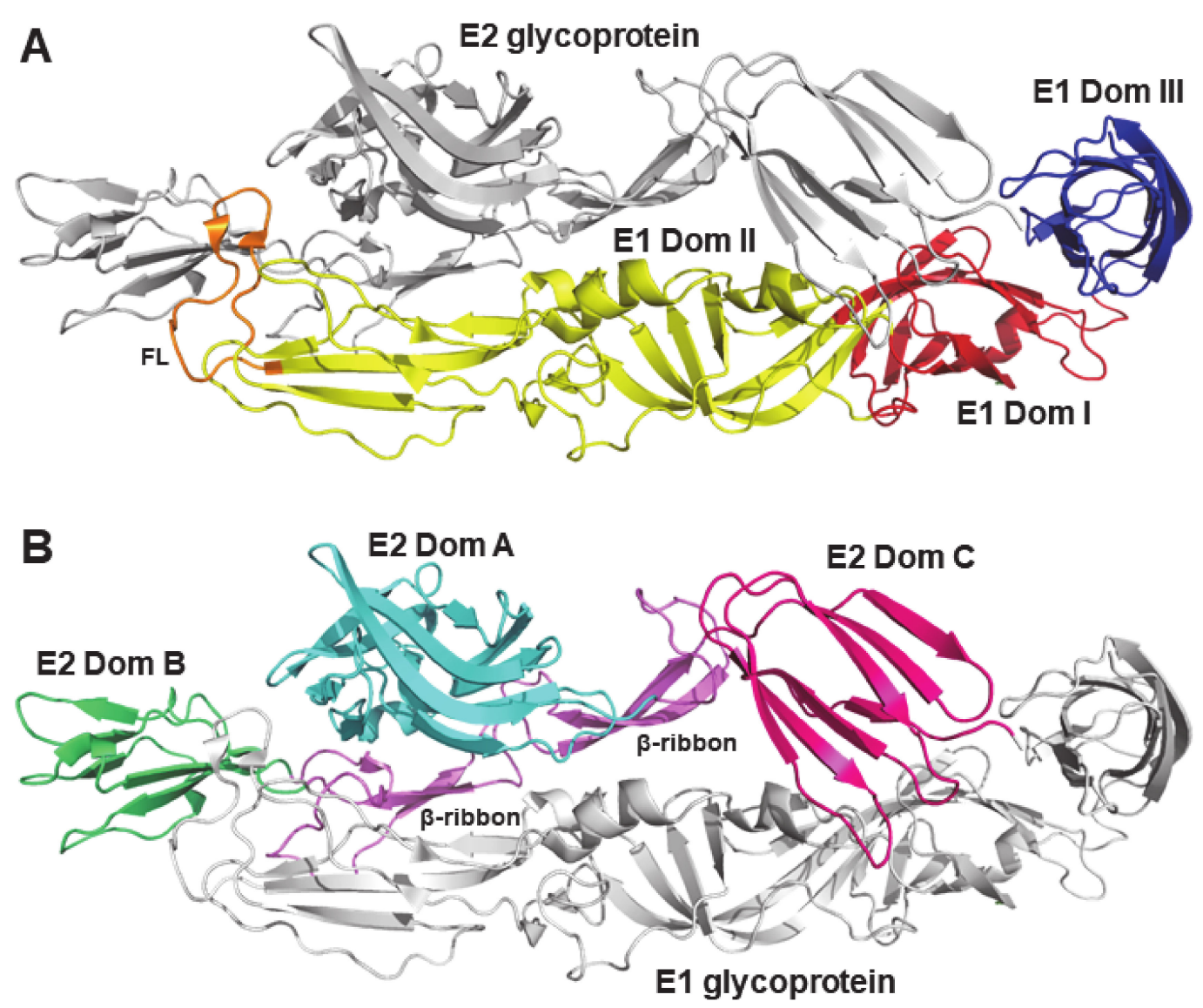

\begin{tabular}{|c|c|c|c|c|c|c|}
\hline & \multicolumn{3}{|c|}{ E1 glycoprotein } & \multicolumn{3}{|c|}{ E2 glycoprotein } \\
\hline & Dom I & Dom II & Dom III & Dom A & Dom B & Dom C \\
\hline CHIKV & & 92 & & $23,90-92$ & $90-92,98$ & 91 \\
\hline \multicolumn{7}{|l|}{ ONNV } \\
\hline MAYV & & 103 & & & 103 & \\
\hline RRV & & & & 102 & 79,102 & \\
\hline SINV & & 83 & & & 80 & 83 \\
\hline EEEV & & & & 99,101 & 99,101 & \\
\hline WEEV & & & & 81 & & \\
\hline VEEV & & & & & 81 & \\
\hline
\end{tabular}

Figure 1. Structure of the alphavirus E1-E2 heterodimer. Ribbon diagram (PDB: 3N41) highlighting (A) E1 glycoprotein (domain I: red, domain II: yellow, domain III: blue, fusion loop FL: orange, E2: grey) and (B) E2 glycoprotein (domain A: cyan, domain B: green, domain C: pink, beta-ribbons: purple, E1: grey). (C) Table summarizing reported antibody binding regions in the E1 and E2 glycoproteins of arthrogenic and neurotropic alphaviruses. Numbers in the table refer to in-text citations describing such binding sites (See Reference list). Background color matches protein doimains depicted in (A) and (B). To assess for the degree of conservation among common antigenic regions across alphaviruses a sequence aligment analysis was conducted (See Supplementary Figure S1). 
The development of mouse and human monoclonal antibodies against different alphaviruses helped further the understanding of antigenic responses upon infection by the identification of conformational epitopes. Early works have shown the therapeutic value of mouse monoclonal antibodies in models of alphavirus encephalitis by SINV [84-88], SFV [56,57,89] and VEEV [78]. Interestingly, it was observed that neutralizing monoclonal antibodies target antigenic regions in the E2 protein. Whereas, non-neutralizing antibodies bind to the E1 protein, yet both are able to confer protection upon alphavirus infection, thereby suggesting other mechanisms of protection in vivo besides virus neutralization [48]. Several monoclonal antibodies targeting both E1 and E2 proteins have been reported in the context of arthritogenic alphavirus infection. Mouse monoclonal antibodies targeting the A and B domain of E2 and the domain II of E1 [90-92] and the capsid protein [93,94] have been reported for CHIKV. Likewise, human anti-CHIKV monoclonal antibodies were found to target conformation epitopes in the E2 glycoprotein A (containing a putative RBD [95]) and B (shielding the fusion loop in E1 [96]) domains and proved therapeutic value in experimental NHP infections $[90,97,98]$. Monoclonal antibodies recognizing epitopes predominantly between residues 58-80 (domains A) or residues 180-215 (domain B) of the E2 glycoprotein have been also reported in the context of SINV [83], VEEV [81], EEEV [99-101], RRV [102] and MAYV [103].

The combined evidence suggested the existence of common antigenic sites in the viral spike across alphaviruses, particularly in the E2 protein. These sites are likely required for interaction with host cell receptors suggesting that antibody binding might inhibit infection during viral attachment, entry, fusion or egress [90]. In line with this, a recent study reported the discovery of Mxra8, a cell adhesion molecule, as a host receptor required for viral entry of multiple arthritogenic alphaviruses [104]. Genetically altering mouse or human Mxra8 resulted in diminished infection, conversely, overexpression of Mxra8 in cell lines increased infection rates by CHIKV, ONNV, MAYV and RRV [104,105]. Interestingly, mutagenesis experiments suggested E2 domains A and B as the putative binding site for Mxra8 [104]. This notion was later confirmed by cryo-electron microscopy images of Mxra8 bound to CHIKV [106,107]. Mxra8 sits onto a cleft formed by two contiguous CHIKV E2-E1 heterodimers in one trimeric spike while engaging a neighboring spike [106]. It is believed that this interaction works against the virus by obstructing viral fusion [106]. Importantly, human neutralizing antibodies that recognize regions of the A domain of E2 inhibited the binding of Mxra8 supporting the interactions determined in the cryo-EM atomic model. Notably, Mxra8 seems to not be a receptor for neurotropic alphaviruses [104]. The alignment of CHIKV residues involved in Mxra8 binding reveled a degree of conservation in arthritogenic alphaviruses (44\%), but diverged from neurotropic Alphaviruses (14\%) which might explain the negative results in the context of SINV, EEEV, WEEV and VEEV infections [106]. In summary, the characterization of alphavirus antigenic epitopes has proven beneficial to pave the way for the development of antibody therapies and vaccines.

\section{Alphavirus Vaccine Development}

Recent decades have seen increased rates of geographic dispersal of arboviral reemergence, due to factors such as growth of global transportation, urbanization and failure of mosquito control [108-111]. Given that humans appear to be the only amplification hosts and viral reservoir during urban transmission [112,113], another effective means of controlling the spread of infection is through vaccination. While there are currently no licensed or approved vaccines available for alphaviruses, a multitude of approaches have been used to develop vaccine candidates capable of, not only generating high levels of antibodies, but also providing long-lasting protection, with the ease of administration and production requirements. Multiple methods such as live-attenuated viruses, inactivated viruses, virus-like particles (VLP), recombinant subunit vaccines and chimeric vaccines have been explored for vaccine options (Figure 2 and Table 1). 


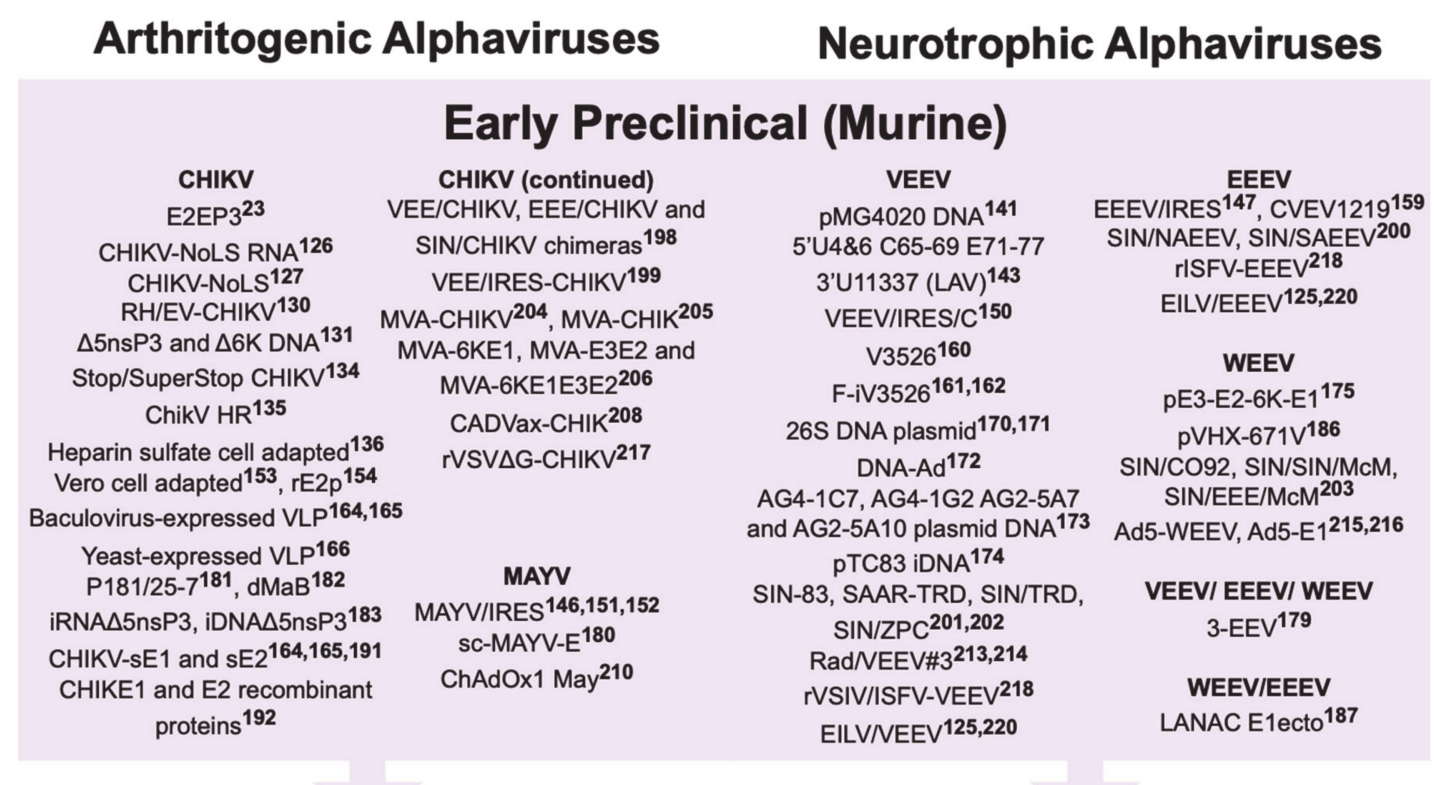

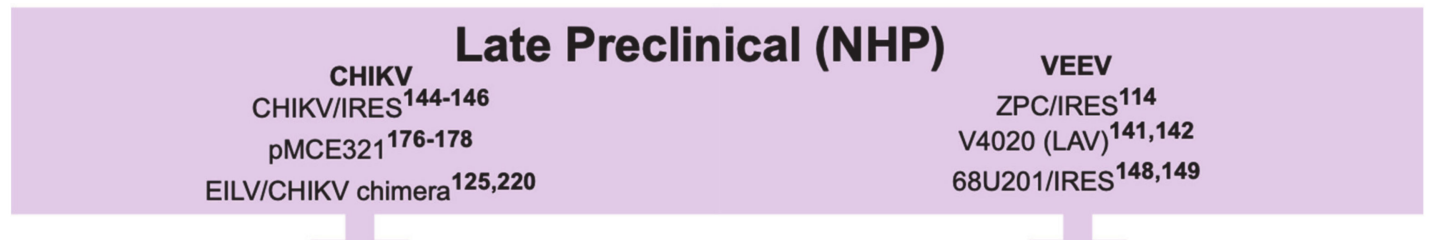

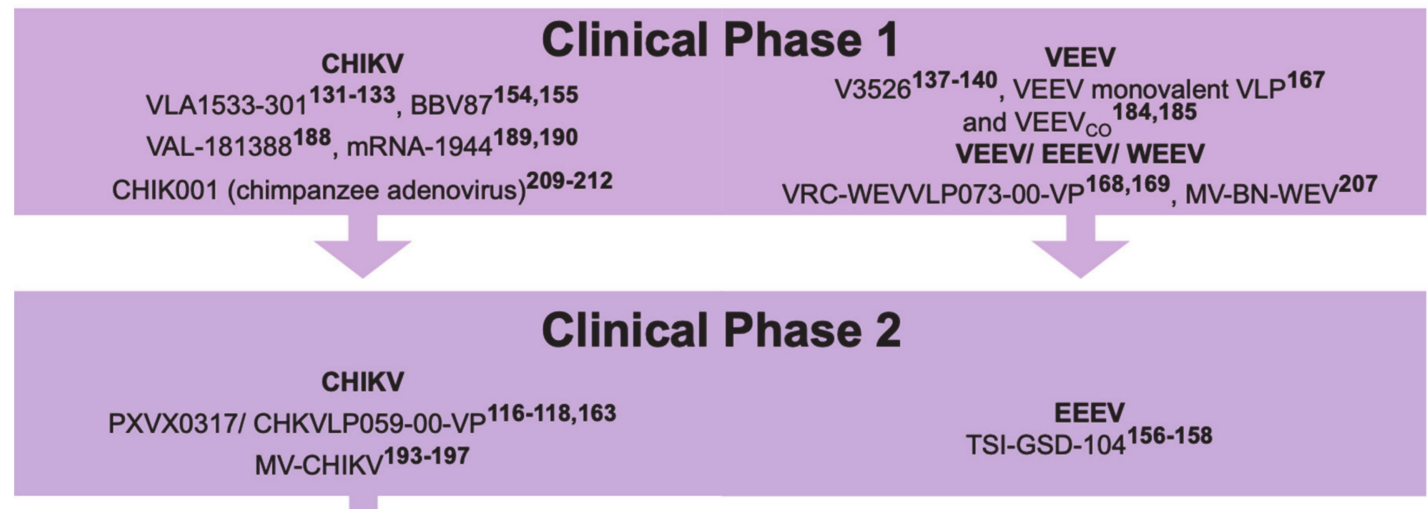

\section{Clinical Phase 3}

Inactivated RRV vaccine $e^{73,115,128,129}$

Figure 2. An outline of the current vaccine options against arthritogenic (left panel) and neurotropic (right panel) alphaviruses. Most of these vaccine candidates are currently under preclinical testing (early preclinical—vaccine candidates tested in mouse models; late preclinical—vaccine candidates currently under testing in non-human primates (NHP)), while a minority of them are currently undergoing clinical trials (Phase 1, 2 or 3). LAV; live-attenuated virus; VLP, virus-like particle; SIN, Sindbis virus; ISFV, Isfahan virus; May, Mayaro virus; EILV, Eilat virus, VSV/VSIV, vesicular stomatitis virus; MV, measles virus; MVA, modified vaccinia virus Ankara. Data curated from literature reported through February 2021. Numbers in superscript refer to reference numbers (See Reference list $[23,73,114-220]$ ). 
Table 1. List of vaccine candidates against relevant alphaviruses currently under development ${ }^{1}$.

\begin{tabular}{|c|c|c|c|c|c|c|c|c|c|c|}
\hline \multirow{2}{*}{$\begin{array}{c}\text { Vaccine } \\
\text { Against Virus }\end{array}$} & \multirow[b]{2}{*}{ Name } & \multirow{2}{*}{$\begin{array}{l}\text { Strain Vaccine } \\
\text { Modelled After }\end{array}$} & \multirow[b]{2}{*}{ Phase } & \multicolumn{3}{|c|}{ Immunization } & \multicolumn{2}{|c|}{ Challenge } & \multirow{2}{*}{$\begin{array}{l}\text { Humoral Immune } \\
\text { Response(s) }\end{array}$} & \multirow[b]{2}{*}{ Ref } \\
\hline & & & & Dose & Route & Schedule & $\begin{array}{l}\text { Dose (Strain, } \\
\text { Genotype) }\end{array}$ & Route & & \\
\hline \multicolumn{11}{|c|}{ Live-attenuated } \\
\hline CHIKV, ONNV & $\begin{array}{l}\text { RH-CHIKV } \\
\text { EV-CHIKV } \\
\text { RHEV-CHIKV }\end{array}$ & LR2006 OPY1 & $\begin{array}{l}\text { C57BL/ } 6 \text { mice, } \\
3 \text { week old }\end{array}$ & $10^{6} \mathrm{PFU}$ & $\begin{array}{l}\text { s.c. in the ventral } \\
\text { side of the right } \\
\text { hind footpad }\end{array}$ & Single dose & $\begin{array}{c}10^{6} \text { PFU LR2006 OPY1 } \\
\text { or WT-ONNV } \\
\text { IMTSSA/5163, } \\
3 \text { mpim }\end{array}$ & $\begin{array}{l}\text { s.c. in the } \\
\text { ventral side of } \\
\text { the right } \\
\text { hind footpad }\end{array}$ & $\begin{array}{c}\text { IC50, } 613 \\
\text { (RH-CHIKV), } 3407 \\
\text { (EV-CHIKV), } 921 \\
\text { (RHEV-CHIKV) }\end{array}$ & [130] \\
\hline \multirow{3}{*}{ CHIKV } & \multirow{3}{*}{$\begin{array}{l}\Delta 5 \mathrm{nsP3} \\
\text { (VLA1553-301 in } \\
\text { clinical trials) } \\
\text { and } \Delta 6 \mathrm{~K}\end{array}$} & \multirow{3}{*}{ LR2006 OPY1 } & $\begin{array}{l}\text { C57BL/ } 6 \text { mice, } 5 \\
\text { to } 6 \text { week old }\end{array}$ & $\begin{array}{c}10^{4} \text { or } \\
10^{5} \mathrm{PFU}\end{array}$ & s.c. in both flanks & Single dose & $\begin{array}{c}10^{6} \text { PFU LR2006 OPY1, } \\
7 \text { wpim }\end{array}$ & s.c. & NT50, 100 to 1000 & \multirow{3}{*}{ [131-133] } \\
\hline & & & $\begin{array}{l}\text { Cynomolgus } \\
\text { macaques, } \\
3-4 \text { years old }\end{array}$ & $10^{5} \mathrm{PFU}$ & $\begin{array}{l}\text { s.c. in the right } \\
\text { upper back side }\end{array}$ & Single dose & $\begin{array}{c}100 \text { AID50 } \\
\text { (corresponding to } \\
\text { 7000-10,000 PFU) } \\
\text { LR2006 OPY1, } \\
\text { 123 dpim } \\
\end{array}$ & i.v. & NT50, $>1000$ & \\
\hline & & & $\begin{array}{l}\text { Human clinical } \\
\text { trial, Phase } 1\end{array}$ & $\begin{array}{c}3.2 \times 10^{3} \\
3.2 \times 10^{4} \text { or } \\
3.2 \times 10^{5} \\
\text { TCID50 }\end{array}$ & i.m. & $\begin{array}{l}\text { Two doses }(0 \\
\text { and } 6 \text { months, } \\
\text { or } 0 \text { and } \\
12 \text { months })\end{array}$ & NA & NA & GMT, 592.6 to 686.9 & \\
\hline CHIKV & $\begin{array}{l}\text { Stop CHIKV } \\
\text { SuperStop } \\
\text { CHIKV }\end{array}$ & LR2006 OPY1 & $\begin{array}{l}\text { C57BL/ } 6 \text { mice, } \\
5 \text { week old }\end{array}$ & $10^{4} \mathrm{PFU}$ & s.c. & Single dose & ND & ND & $\begin{array}{c}\sim 5-25 \text { (Stop CHIKV) } \\
\text { and } \sim 10-25 \\
\text { (SuperStop CHIKV) } \\
\text { fold reduction } \\
\text { compared to mock }\end{array}$ & [134] \\
\hline CHIKV & ChikV HR & 37997 & $\begin{array}{l}\text { C57BL/ } 6 \text { mice, } \\
28 \text { days of age }\end{array}$ & $\sim 10^{3} \mathrm{PFU}$ & $\begin{array}{l}\text { s.c. into the } \\
\text { left footpad }\end{array}$ & Single dose & $\begin{array}{l}10^{3} \text { PFU CHIKV } \\
\text { SL15649, } 28 \text { dpim }\end{array}$ & $\begin{array}{l}\text { s.c. in the } \\
\text { footpad }\end{array}$ & PRNT50, 5 to $\sim 500$ & [135] \\
\hline CHIKV & $\begin{array}{l}\text { Heparin } \\
\text { sulfate cell } \\
\text { culture adapted }\end{array}$ & LR2006 OPY1 & $\begin{array}{l}\text { CD-1 mice, } \\
21 \text { days old }\end{array}$ & $10^{5} \mathrm{GE}$ & $\begin{array}{l}\text { s.c. in the } \\
\text { rear footpad }\end{array}$ & Single dose & $\begin{array}{c}10^{3} \text { PFU LR2006 OPY1, } \\
21 \text { dpim }\end{array}$ & NA & $\begin{array}{l}\sim 40 \text { to } 1000 \text { fold } \\
\text { change compared } \\
\text { to mock }\end{array}$ & [136] \\
\hline
\end{tabular}


Table 1. Cont.

\begin{tabular}{|c|c|c|c|c|c|c|c|c|c|c|}
\hline \multirow{2}{*}{$\begin{array}{c}\text { Vaccine } \\
\text { Against Virus }\end{array}$} & \multirow[b]{2}{*}{ Name } & \multirow[b]{2}{*}{$\begin{array}{l}\text { Strain Vaccine } \\
\text { Modelled After }\end{array}$} & \multirow[b]{2}{*}{ Phase } & \multicolumn{3}{|c|}{ Immunization } & \multicolumn{2}{|c|}{ Challenge } & \multirow[b]{2}{*}{$\begin{array}{c}\text { Humoral Immune } \\
\text { Response(s) }\end{array}$} & \multirow[b]{2}{*}{ Ref } \\
\hline & & & & Dose & Route & Schedule & $\begin{array}{l}\text { Dose (Strain, } \\
\text { Genotype) }\end{array}$ & Route & & \\
\hline \multirow{4}{*}{ VEEV } & \multirow{4}{*}{ V3526 } & \multirow{4}{*}{$\begin{array}{c}\text { IA/B } \\
\text { Trinidad donkey }\end{array}$} & $\begin{array}{c}\text { BALB } / \mathrm{c}, 6 \text { to } \\
8 \text { week } \\
\text { oldC3H/HeN } \\
\text { mice, } 6 \text { to } \\
8 \text { week old }\end{array}$ & $10^{5} \mathrm{PFU}$ & s.c. & Single dose & $\begin{array}{l}10^{5} \text { PFU of TrD, } \\
28 \text { dpim }\end{array}$ & NP & ND & \multirow{4}{*}{ [137-140] } \\
\hline & & & $\begin{array}{l}\text { Cynomolgus } \\
\text { macaques (age } \\
\text { not specified) }\end{array}$ & $2.5 \times 10^{6} \mathrm{PFU}$ & s.c. & Single dose & $\begin{array}{l}\sim 10^{8} \text { PFU VEEV IE } \\
68 \mathrm{U} 201,8 \text { wpim }\end{array}$ & aerosol & PRNT80, 28 to 2560 & \\
\hline & & & $\begin{array}{c}\text { Rhesus } \\
\text { macaques ( } 2 \text { to } 4 \\
\text { years old) }\end{array}$ & $\begin{array}{l}1.3 \times 10^{5} \text { or } \\
7.5 \times 10^{4} \mathrm{PFU}\end{array}$ & s.c. or i.t./i.s. & Single dose & ND & ND & PRNT80, 80 to 300 & \\
\hline & & & $\begin{array}{l}\text { Human clinical } \\
\text { trial, Phase } 1\end{array}$ & $\begin{array}{c}25 \text { or } \\
125 \text { PFU }\end{array}$ & s.c. & Single dose & NA & NA & NA & \\
\hline \multirow[b]{2}{*}{ VEEV } & \multirow[b]{2}{*}{ V4020 } & \multirow[b]{2}{*}{$\begin{array}{l}\text { IA/B Trinidad } \\
\text { donkey }\end{array}$} & $\begin{array}{l}\text { BALB/c mice, } 4 \\
\text { to } 8 \text { week old }\end{array}$ & $10^{4} \mathrm{PFU}$ & s.c. & Single dose & $\begin{array}{l}10^{4} \text { PFU of VEEV TrD, } \\
28 \text { dpim }\end{array}$ & s.c. & PRNT80, 160 to1280 & \multirow[b]{2}{*}[141,142]{} \\
\hline & & & $\begin{array}{l}\text { Cynomolgus } \\
\text { macaques (age } \\
\text { not specified) }\end{array}$ & $\sim 10^{4} \mathrm{PFU}$ & s.c. in the right leg & $\begin{array}{l}\text { Single dose (or } \\
\text { second dose at } \\
2 \times 10^{4} \mathrm{PFU} \\
\text { i.m. if did not } \\
\text { seroconvert) }\end{array}$ & $\begin{array}{l}10^{6} \text { to } 10^{7} \text { PFU of the } \\
\text { VEEV TrD, } 73 \text { dpim }\end{array}$ & aerosol & PRNT80, >640 & \\
\hline EEEV & $\begin{array}{c}5^{\prime} \mathrm{U} 4 \& 6 \\
\text { C65-69 E71-77 } \\
\text { 3'U11337 mutants }^{\prime}\end{array}$ & FL93-939 & $\begin{array}{l}\text { CD-1 mice, } 5 \text { to } \\
6 \text { week old }\end{array}$ & $1.5 \times 10^{5} \mathrm{GE}$ & $\begin{array}{l}\text { s.c. in footpad, } \\
\text { or i.c. }\end{array}$ & Single dose & $\begin{array}{l}10^{5} \text { PFU EEEV FL93, } \\
21 \text { dpim }\end{array}$ & $\begin{array}{l}\text { s.c. in } \\
\text { both footpads }\end{array}$ & PRNT80, 16 to $\sim 4000$ & [143] \\
\hline Live-atter & ated (IRES) & & & & & & & & & \\
\hline \multirow{4}{*}{ CHIKV } & \multirow{4}{*}{ CHIKV/IRES } & \multirow{4}{*}{ LR2006 OPY1 } & $\begin{array}{l}\text { A129 mice, } 3 \text { or } \\
10 \text { week old }\end{array}$ & $10^{4} \mathrm{PFU}$ & i.d. & Single dose & $\begin{array}{l}100 \text { PFU LR2006 OPY1, } \\
94 \text { dpim }\end{array}$ & i.d. & PRNT80, >320 & \multirow{4}{*}[144,145]{} \\
\hline & & & $\begin{array}{l}\text { C57BL } / 6 \text { mice, } \\
3 \text { week old }\end{array}$ & $10^{5} \mathrm{PFU}$ & s.c. in the hind leg & Single dose & $\begin{array}{c}10^{6.5} \text { PFU Ross CHIKV, } \\
21 \mathrm{dpim}\end{array}$ & i.n. & Mean PRNT80, 62 & \\
\hline & & & $\begin{array}{l}\text { A129 mice, } 8 \text { to } \\
10 \text { week old }\end{array}$ & $10^{5}$ TCID50 & s.c. & Single dose & $\begin{array}{l}100 \text { PFU LR2006 OPY1, } \\
50 \text { dpim }\end{array}$ & i.d. & Mean PRNT80, 1152 & \\
\hline & & & $\begin{array}{l}\text { Cynomolgus } \\
\text { macaques, } \\
>3 \text { years old }\end{array}$ & $10^{5} \mathrm{PFU}$ & s.c. or i.d. & Single dose & $\begin{array}{l}10^{5} \text { PFU LR2006 OPY1, } \\
52 \text { dpim }\end{array}$ & $\begin{array}{l}\text { s.c. in the } \\
\text { upper deltoid }\end{array}$ & $\begin{array}{l}\text { PRNT80, } 40 \text { to } \\
640 \text { PRNT50, } \\
160 \text { to } 1280\end{array}$ & \\
\hline
\end{tabular}


Table 1. Cont.

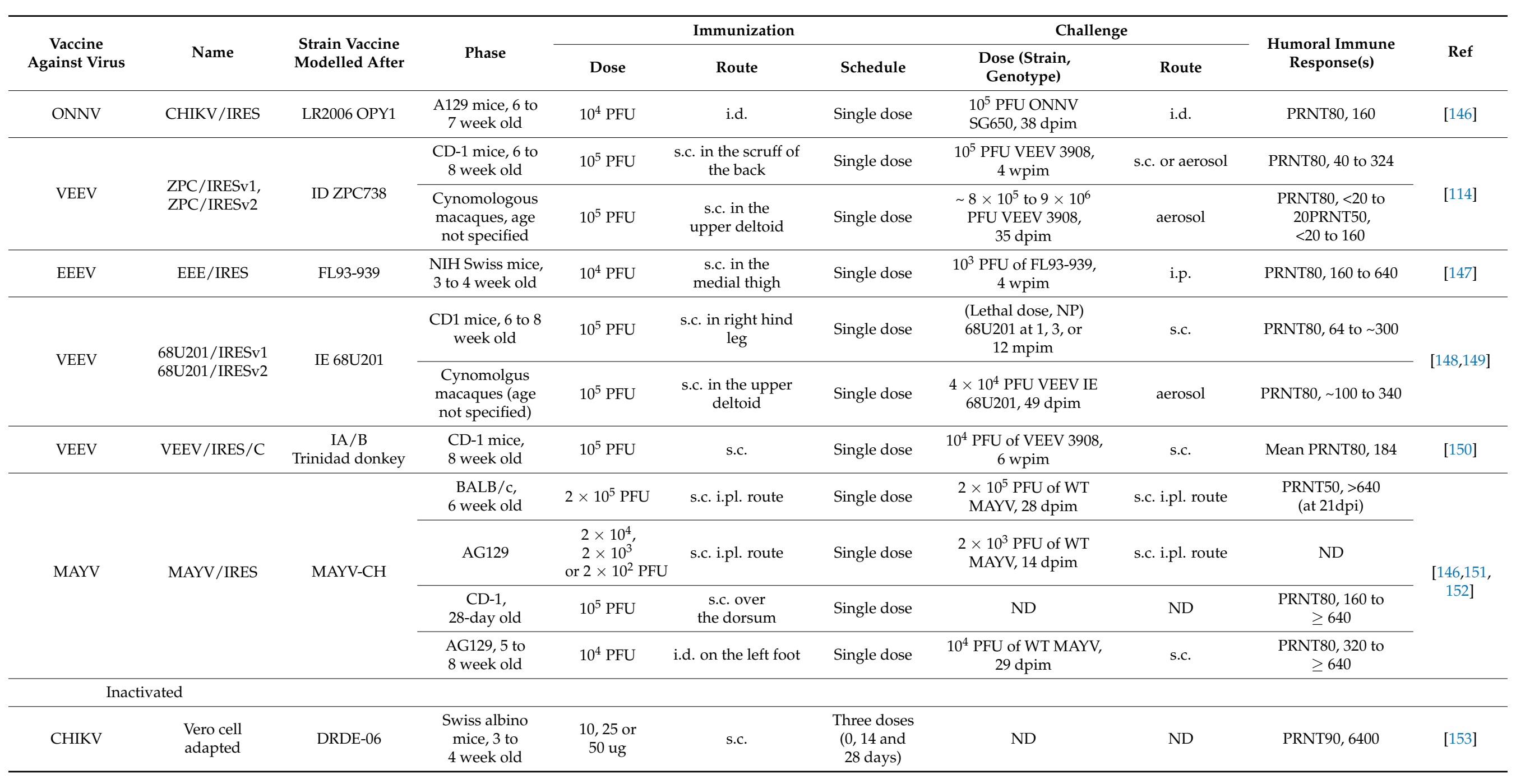


Table 1. Cont.

\begin{tabular}{|c|c|c|c|c|c|c|c|c|c|c|}
\hline \multirow{2}{*}{$\begin{array}{c}\text { Vaccine } \\
\text { Against Virus }\end{array}$} & \multirow[b]{2}{*}{ Name } & \multirow{2}{*}{$\begin{array}{l}\text { Strain Vaccine } \\
\text { Modelled After }\end{array}$} & \multirow[b]{2}{*}{ Phase } & \multicolumn{3}{|c|}{ Immunization } & \multicolumn{2}{|c|}{ Challenge } & \multirow{2}{*}{$\begin{array}{c}\text { Humoral Immune } \\
\text { Response(s) }\end{array}$} & \multirow[b]{2}{*}{ Ref } \\
\hline & & & & Dose & Route & Schedule & $\begin{array}{l}\text { Dose (Strain, } \\
\text { Genotype) }\end{array}$ & Route & & \\
\hline \multirow{2}{*}{ CHIKV } & \multirow{2}{*}{$\begin{array}{l}\text { BPL/formalin- } \\
\text { inactivated } \\
\text { CHIKV } \\
\text { BBV87 (in } \\
\text { clinical trials) }\end{array}$} & \multirow{2}{*}{ IND-06-AP3 } & $\begin{array}{l}\text { BALB } / \mathrm{c} \text { mice, } 4 \\
\text { to } 6 \text { week old }\end{array}$ & $\begin{array}{l}10,20 \text { or } \\
50 \mu \mathrm{g}\end{array}$ & i.m. & $\begin{array}{l}\text { Two doses } \\
\text { (0 and } 14 \text { days) }\end{array}$ & $\begin{array}{l}2.5 \times 10^{4} \text { TCID50 } \\
\text { IND-06-AP3, } 4 \text { or } \\
22 \text { wpim }\end{array}$ & i.n. & $\begin{array}{l}\text { GMT, NT50, } \\
80 \text { to } 1280\end{array}$ & [154] \\
\hline & & & $\begin{array}{l}\text { Human clinical } \\
\text { trial, Phase } 1\end{array}$ & $\begin{array}{l}10,20 \text { or } \\
30 \mu \mathrm{g}\end{array}$ & i.m. & $\begin{array}{l}\text { Three doses } \\
\text { (0,29 and } \\
57 \text { days })\end{array}$ & NA & NA & NA & [155] \\
\hline \multirow{5}{*}{ RRV } & \multirow{5}{*}{$\begin{array}{c}\text { Vero cell } \\
\text { culture-derived } \\
\text { whole-virus } \\
\text { RRV vaccine } \\
\text { Ross River Virus } \\
\text { (RRV) Vaccine }\end{array}$} & \multirow{5}{*}{$\mathrm{T} 48$} & $\begin{array}{l}\text { A129 mice, } 7 \text { to } \\
8 \text { week old }\end{array}$ & $\begin{array}{l}0.063,0.25 \\
\text { or } 1 \mu \mathrm{g}\end{array}$ & i.m. & $\begin{array}{c}\text { Two doses } \\
(0 \text { and } 21 \text { days) } \\
\end{array}$ & $\begin{array}{l}10^{2.5} \text { TCID50 T48, } \\
42 \text { dpim }\end{array}$ & $\begin{array}{c}\text { s.c. into } \\
\text { left footpad }\end{array}$ & Mean NT, $\leq 14$ to 21 & \multirow{5}{*}{$\begin{array}{l}\text { [73,115, } \\
128,129]\end{array}$} \\
\hline & & & $\begin{array}{l}\text { CD-1 mice, age } \\
\text { not specified }\end{array}$ & $10 \mu \mathrm{g}$ & s.c. & $\begin{array}{c}\text { Two doses } \\
\text { ( } 0 \text { and } 28 \text { days) } \\
\end{array}$ & $\begin{array}{l}10^{6} \text { TCID50 T48, } \\
6 \text { wpim }\end{array}$ & i.v. & 1000 TCID50 & \\
\hline & & & $\begin{array}{l}\text { Guinea pigs } \\
\text { (Duncan } \\
\text { Hartley), age } \\
\text { not specified } \\
\end{array}$ & $10 \mu \mathrm{g}$ & s.c. & $\begin{array}{l}\text { Single or two } \\
\text { doses (0 and } \\
6 \text { weeks })\end{array}$ & $\begin{array}{c}10^{6} \text { TCID50 T48, } 10 \text { or } \\
34 \text { wpim }\end{array}$ & i.v. & $\mathrm{NP}$ & \\
\hline & & & $\begin{array}{l}\text { Human clinical } \\
\text { trial, Phase } 1 / 2\end{array}$ & $\begin{array}{l}1.25,2.5,5 \\
\text { or } 10 \mu \mathrm{g}\end{array}$ & i.m. & $\begin{array}{c}\text { Three doses in } \\
\text { escalation }(0, \\
21 \text { days, } \\
6 \text { months) }\end{array}$ & NA & NA & GMT, 50 to 520.9 & \\
\hline & & & $\begin{array}{l}\text { Human clinical } \\
\text { trial, Phase } 3\end{array}$ & $2.5 \mathrm{ug}$ & i.m. & $\begin{array}{c}\text { Three doses }(0, \\
3 \text { weeks, } \\
6 \text { months })\end{array}$ & NA & NA & $\mu \mathrm{NT}$ GMT, $\sim 0$ to 85 & \\
\hline EEEV & $\begin{array}{l}\text { TSI-GSD-104 } \\
\text { (formalin } \\
\text { inactivated) }\end{array}$ & PE-6 & $\begin{array}{l}\text { Human clinical } \\
\text { trial, Phase } 2\end{array}$ & NP & $\begin{array}{l}\text { s.c. }(0 \text { and } 28 \\
\text { days), i.d. } \\
(6 \text { months })\end{array}$ & $\begin{array}{l}\text { Three doses }(0, \\
28 \text { days and } \\
6 \text { months) }\end{array}$ & NA & NA & $\begin{array}{l}\text { PRNT80 }>40 \text { in } 60 \% \\
\text { subjects (primary } \\
\text { doses) versus } 84 \% \\
\text { subjects (completed } \\
\text { the 2-dose primary } \\
\text { series and the } \\
\text { 6-month dose) }\end{array}$ & [156-158] \\
\hline
\end{tabular}


Table 1. Cont.

\begin{tabular}{|c|c|c|c|c|c|c|c|c|c|c|}
\hline \multirow{2}{*}{$\begin{array}{c}\text { Vaccine } \\
\text { Against Virus }\end{array}$} & \multirow[b]{2}{*}{ Name } & \multirow{2}{*}{$\begin{array}{l}\text { Strain Vaccine } \\
\text { Modelled After }\end{array}$} & \multirow[b]{2}{*}{ Phase } & \multicolumn{3}{|c|}{ Immunization } & \multicolumn{2}{|c|}{ Challenge } & \multirow{2}{*}{$\begin{array}{l}\text { Humoral Immune } \\
\text { Response(s) }\end{array}$} & \multirow[b]{2}{*}{ Ref } \\
\hline & & & & Dose & Route & Schedule & $\begin{array}{l}\text { Dose (Strain, } \\
\text { Genotype) }\end{array}$ & Route & & \\
\hline EEEV & $\begin{array}{l}\text { fCVEV1219 } \\
\text { iCVEV1219 } \\
\text { gCVEV1219 }\end{array}$ & CVEV1219 & $\begin{array}{l}\text { BALB } / \mathrm{c} \text { mice, } 6 \\
\text { to } 8 \text { week old }\end{array}$ & $\begin{array}{c}0.1 \text { to } \\
5 \mu \mathrm{g} \text { of } \\
\text { inactivated } \\
\text { EEEV }\end{array}$ & i.n., s.c. or i.m. & $\begin{array}{l}\text { Single dose or } \\
\text { two doses } \\
(0 \text { and } 28 \text { days })\end{array}$ & $\begin{array}{l}\text { Lethal dose of EEEV } \\
\text { FL93-939, at } 28 \mathrm{dpim} \\
\text { (single dose) or } \\
56 \text { dpim (two doses) }\end{array}$ & aerosol & PRNT80, 1 to 1000 & [159] \\
\hline VEEV & V3526 virus & V3526 & $\begin{array}{l}\text { BALB } / \mathrm{c} \text { mice, } \\
6 \text { week old }\end{array}$ & $\begin{array}{c}0.2 \mu \mathrm{g} \text { (s.c.) } \\
\text { or } \\
0.04 \mu \mathrm{g} \text { (i.m.) }\end{array}$ & s.c. or i.m. & $\begin{array}{c}\text { Two doses } \\
\text { (0 and } 28 \text { days) }\end{array}$ & $\begin{array}{l}10^{4} \text { PFU VEEV TrD, } \\
56 \text { dpim }\end{array}$ & aerosol or s.c. & $\begin{array}{l}\text { GMT PRNT80, } \\
\sim 60 \text { to } 2500\end{array}$ & {$[160]$} \\
\hline VEEV & F-iV3526 & V3526 & $\begin{array}{l}\text { BALB /c mice, } 8 \\
\text { to } 10 \text { weeks old }\end{array}$ & 1,3 or $5 \mu \mathrm{g}$ & $\begin{array}{l}\text { i.n., s.c. (under the } \\
\text { skin over the neck) } \\
\text { or i.m. (thigh } \\
\text { muscle of the } \\
\text { hind leg) }\end{array}$ & Single dose & $\begin{array}{l}454 \text { (i.n.), } 897 \text { (i.m.) or } \\
55 \text { (s.c.) PFU } \\
\text { VEEV-TrD, } 56 \text { dpim }\end{array}$ & aerosol & $\begin{array}{l}\text { Microneutralization } \\
\text { titer of } 100 \text { to } 3500\end{array}$ & {$[161,162]$} \\
\hline \multicolumn{11}{|c|}{ Virus-like particle } \\
\hline \multirow{5}{*}{ CHIKV } & \multirow{5}{*}{$\begin{array}{c}\text { VRC } 311 \\
\text { Or } \\
\text { VRC- } \\
\text { CHKVLP059-00- } \\
\text { VP / PXVX0317 } \\
\text { (in clinical trials) }\end{array}$} & \multirow{5}{*}{37997} & $\begin{array}{l}\text { BALB /c mice, } 6 \\
\text { to } 8 \text { week old }\end{array}$ & $19 \mu \mathrm{g}$ & i.m. & $\begin{array}{l}2 \text { doses ( } 2 \text { and } \\
5 \text { weeks) }\end{array}$ & ND & ND & IC 50,10703 to 54600 & \multirow{5}{*}{$\begin{array}{c}{[116-} \\
118,163]\end{array}$} \\
\hline & & & $\begin{array}{l}\text { Cynomolgus } \\
\text { macaques, } 3 \text { to } \\
4 \text { years old }\end{array}$ & $20 \mu \mathrm{g}$ & i.m. & $\begin{array}{l}3 \text { doses }(0,4 \\
\text { and } 24 \text { weeks) }\end{array}$ & $\begin{array}{l}10^{10} \text { PFU LR2006 } \\
\text { OPY1, } 15 \text { wpim }\end{array}$ & i.v. & IC 50,10219 to 15072 & \\
\hline & & & $\begin{array}{l}\text { Human clinical } \\
\text { trial, Phase } 1\end{array}$ & $\begin{array}{c}10,20 \text { or } \\
40 \mu \mathrm{g}\end{array}$ & i.m. & $\begin{array}{l}3 \text { doses }(0,4 \\
\text { and } 24 \text { weeks) }\end{array}$ & NA & NA & IC50, 4525 to 8745 & \\
\hline & & & $\begin{array}{l}\text { Human, clinical } \\
\text { trial Phase } 2\end{array}$ & $20 \mu \mathrm{g}$ & i.m. & $\begin{array}{l}2 \text { doses }(0 \text { and } \\
28 \text { days })\end{array}$ & NA & NA & EC50 GMT, 2005 & \\
\hline & & & $\begin{array}{l}\text { Human clinical } \\
\text { trial (Phase } 2 \mathrm{~b} \text {, } \\
\text { recruitment } \\
\text { completed) }\end{array}$ & $\begin{array}{c}6,10 \text { or } \\
20 \mu \mathrm{g}\end{array}$ & NP & $\begin{array}{l}\text { Two doses } \\
\text { ( } 0 \text { and } 14 \text { or } \\
28 \text { days })\end{array}$ & NA & NA & NA & \\
\hline \multirow{2}{*}{ CHIKV } & \multirow{2}{*}{$\begin{array}{l}\text { Baculovirus- } \\
\text { expressed VLP }\end{array}$} & \multirow{2}{*}{ S27 } & $\begin{array}{c}\text { AG129, } \\
6 \text { week old }\end{array}$ & $1 \mu \mathrm{g}$ & s.c. & $\begin{array}{l}2 \text { doses }(0 \text { and } \\
21 \text { days })\end{array}$ & $\begin{array}{l}1000 \text { TCID50 S27, } \\
6 \text { wpim }\end{array}$ & i.p. & PRNT95, 40 to 80 & {$[164,165]$} \\
\hline & & & $\begin{array}{l}\text { C57BL/ } 6 \text { mice, } 6 \\
\text { to } 12 \text { week old }\end{array}$ & 0.1 or $1 \mu \mathrm{g}$ & s.c. & Single dose & $\begin{array}{l}10^{4} \text { CCID }_{50} \text { LR2006 } \\
\text { OPY1, } 6 \text { wpim }\end{array}$ & s.c. & NT95, 1,100 & \\
\hline CHIKV & $\begin{array}{l}\text { Yeast-expressed } \\
\text { VLP }\end{array}$ & DRDE06/DRDE07 & $\begin{array}{c}\text { BALB/c mice, } 4 \\
\text { week or } \\
2 \text { days old }\end{array}$ & $\begin{array}{l}10,20 \text { or } \\
40 \mathrm{ug}\end{array}$ & s.c. & $\begin{array}{c}\text { Three doses } \\
(0,14 \text { and } \\
28 \text { days })\end{array}$ & ND & ND & NT50, 128 to 2048 & [166] \\
\hline
\end{tabular}


Table 1. Cont.

\begin{tabular}{|c|c|c|c|c|c|c|c|c|c|c|}
\hline \multirow{2}{*}{$\begin{array}{c}\text { Vaccine } \\
\text { Against Virus }\end{array}$} & \multirow[b]{2}{*}{ Name } & \multirow{2}{*}{$\begin{array}{l}\text { Strain Vaccine } \\
\text { Modelled After }\end{array}$} & \multirow[b]{2}{*}{ Phase } & \multicolumn{3}{|c|}{ Immunization } & \multicolumn{2}{|c|}{ Challenge } & \multirow{2}{*}{$\begin{array}{c}\text { Humoral Immune } \\
\text { Response(s) }\end{array}$} & \multirow[b]{2}{*}{ Ref } \\
\hline & & & & Dose & Route & Schedule & $\begin{array}{l}\text { Dose (Strain, } \\
\text { Genotype) }\end{array}$ & Route & & \\
\hline VEEV & $\begin{array}{c}\text { Venezuelan } \\
\text { Equine } \\
\text { Encephalitis } \\
\text { Monovalent } \\
\text { Virus-Like } \\
\text { Particle } \\
\text { Vaccine (VEEV) }\end{array}$ & NA & $\begin{array}{c}\text { Human clinical } \\
\text { trial (Phase 1, } \\
\text { not recruiting) }\end{array}$ & $\begin{array}{c}2,10, \text { or } \\
20 \mu \mathrm{g}\end{array}$ & i.m. & $\begin{array}{c}\text { Dose } \\
\text { escalation } \\
(0,28 \text { days, } \\
\text { and day } \\
140 \text { booster })\end{array}$ & NA & NA & NA & [167] \\
\hline \multirow{3}{*}{$\begin{array}{l}\text { WEEV, EEEV, } \\
\text { and VEEV }\end{array}$} & \multirow{3}{*}{$\begin{array}{c}\text { VRC- } \\
\text { WEVVLP073 } \\
\text {-00-VP } \\
\text { (Trivalent vaccine) }\end{array}$} & \multirow{3}{*}{$\begin{array}{l}\text { WEEV CBA87, } \\
\text { EEEV PE-6 and } \\
\text { VEEV TC-83 }\end{array}$} & $\begin{array}{l}\text { BALB/c mice, } 6 \\
\text { to } 8 \text { week old }\end{array}$ & $\begin{array}{l}\text { monovalent } \\
(5 \mu \mathrm{g}) \text { or } \\
\text { trivalent } \\
(5 \mu \mathrm{g} \text { each })\end{array}$ & i.m. & $\begin{array}{l}\text { Two doses } \\
\text { (0 and } 21 \text { days) }\end{array}$ & $\begin{array}{c}2.5 \times 10^{3} \text { PFU WEEV } \\
\text { CBA87, } 8.9 \times 10^{3} \mathrm{PFU} \\
\text { EEEV FL93-939, and } \\
1.3 \times 10^{3} \text { PFU VEEV } \\
\text { Trinidad donkey, } \\
56 \text { dpim }\end{array}$ & aerosol & $\begin{array}{l}\text { PRNT80, } 250 \\
\text { to } 100000\end{array}$ & \multirow{2}{*}{ [168] } \\
\hline & & & $\begin{array}{l}\text { Cynomolgus } \\
\text { macaques, age } \\
\text { not specified }\end{array}$ & $\begin{array}{l}\text { Monovalent } \\
(20 \mu \mathrm{g}) \text { or } \\
\text { trivalent } \\
(20 \mu \mathrm{g} \text { each })\end{array}$ & i.m. & $\begin{array}{l}\text { Two doses } \\
\text { (0 and } 28 \text { days) }\end{array}$ & $\begin{array}{c}10^{6} \text { PFU WEEV } \\
\text { CBA87, } 10^{8} \text { PFU EEEV } \\
\text { FL93-939, and } 10^{8} \\
\text { VEEV Trinidad } \\
\text { donkey, } 56 \text { dpim }\end{array}$ & aerosol & $\begin{array}{l}\text { PRNT80, } 1000 \\
\quad \text { to } 10000\end{array}$ & \\
\hline & & & $\begin{array}{l}\text { Human clinical } \\
\text { trial, Phase } 1\end{array}$ & $\begin{array}{l}6,30 \text { or } \\
60 \mu \mathrm{g}\end{array}$ & i.m. & $\begin{array}{c}\text { Dose } \\
\text { escalation } \\
(0 \text { and } 8 \text { weeks })\end{array}$ & NA & NA & NA & [169] \\
\hline \multicolumn{11}{|l|}{ DNA/RNA } \\
\hline \multirow{2}{*}{ VEEV } & \multirow{2}{*}{$\begin{array}{l}\text { VEEV 26S DNA } \\
\text { plasmid }\end{array}$} & \multirow{2}{*}{ I/AB $\operatorname{TrD}$} & $\begin{array}{l}\text { BALB / c mice, } 6 \\
\text { to } 8 \text { week old }\end{array}$ & $\sim 3 \mu \mathrm{g}$ & $\begin{array}{l}\text { DNA/gene gun, } \\
\text { delivered to two } \\
\text { sites on the } \\
\text { abdomen of } \\
\text { each mouse }\end{array}$ & $\begin{array}{l}\text { Three doses } \\
\text { (at 3-week } \\
\text { intervals) }\end{array}$ & $\begin{array}{l}\sim 10^{4} \mathrm{PFU} \text { of } \operatorname{TrD} \\
\quad 9 \text { wpim }\end{array}$ & s.c., aerosol & $\begin{array}{l}\text { PRNT50, GMT } \\
\quad<1.6 \text { to } 2.5\end{array}$ & \multirow{2}{*}[170,171]{} \\
\hline & & & $\begin{array}{l}\text { Hartley guinea } \\
\text { pigs, age } \\
\text { not specified }\end{array}$ & $\sim 5 \mu \mathrm{g}$ & $\begin{array}{l}\text { DNA/gene gun, } \\
\text { delivered to two } \\
\text { sites on the } \\
\text { abdomen of } \\
\text { each mouse }\end{array}$ & $\begin{array}{l}\text { Three doses }(0, \\
4 \text { and } 8 \text { weeks) }\end{array}$ & $\begin{array}{l}\sim 10^{4} \mathrm{PFU} \text { of } \operatorname{TrD}, \\
21 \text { wpim }\end{array}$ & aerosol & PRNT50, 0 to 640 & \\
\hline
\end{tabular}


Table 1. Cont.

\begin{tabular}{|c|c|c|c|c|c|c|c|c|c|c|}
\hline \multirow{2}{*}{$\begin{array}{c}\text { Vaccine } \\
\text { Against Virus }\end{array}$} & \multirow[b]{2}{*}{ Name } & \multirow{2}{*}{$\begin{array}{l}\text { Strain Vaccine } \\
\text { Modelled After }\end{array}$} & \multirow[b]{2}{*}{ Phase } & \multicolumn{3}{|c|}{ Immunization } & \multicolumn{2}{|c|}{ Challenge } & \multirow{2}{*}{$\begin{array}{c}\text { Humoral Immune } \\
\text { Response(s) }\end{array}$} & \multirow[b]{2}{*}{ Ref } \\
\hline & & & & Dose & Route & Schedule & $\begin{array}{l}\text { Dose (Strain, } \\
\text { Genotype) }\end{array}$ & Route & & \\
\hline VEEV & DNA-Ad & TC-83 & $\begin{array}{l}\text { BALB/c mice, } 6 \\
\text { to } 8 \text { week old }\end{array}$ & $\begin{array}{c}1 \mu \mathrm{g} \text { of } \\
\text { DNA per } \\
\text { dose and } \\
107 \text { PFU of } \\
\text { RAd/VEEV } \\
\# 3 \text { per boost }\end{array}$ & gene guni.n. & $\begin{array}{l}\text { immunised } \\
\text { with the DNA } \\
\text { vaccines on } \\
\text { day } 0,14 \text { and } \\
28 \text { and } \\
\text { Ad-based } \\
\text { vaccine on } \\
\text { day } 42\end{array}$ & $\begin{array}{l}100 \text { LD50 of virulent } \\
\text { airborne VEEV, } \\
63 \mathrm{dpim}\end{array}$ & aerosol & PRNT50, 160 & [172] \\
\hline VEEV & $\begin{array}{c}\text { AG4-1C7 } \\
\text { AG4-1G2 } \\
\text { AG2-5A7 } \\
\text { AG2-5A10 } \\
\text { plasmid DNA }\end{array}$ & $\mathrm{I} / \mathrm{AB} \operatorname{TrD}$ & $\begin{array}{l}\text { BALB/c mice, } 6 \\
\text { to } 8 \text { week old }\end{array}$ & $4 \mu \mathrm{g}$ & $\begin{array}{l}\text { particle-mediated } \\
\text { epidermal } \\
\text { delivery (i.d.) }\end{array}$ & $\begin{array}{l}\text { Three doses } \\
\text { (at 3-week } \\
\text { intervals) }\end{array}$ & $\begin{array}{c}\sim 10^{4} \text { PFU of VEEV } \\
\operatorname{TrD}(\geq 1000 \text { LD50) } \\
\quad 70 \text { dpim }\end{array}$ & aerosol & $\begin{array}{l}\text { PRNT80, } 1 \text { to } \\
5.5 \log _{10} \text { GMT }\end{array}$ & [173] \\
\hline VEEV & pTC83 iDNA & TC-83 & $\begin{array}{l}\text { BALB } / \text { c mice, } \\
3 \text { week old }\end{array}$ & $50 \mu \mathrm{g}$ & $\begin{array}{c}\text { i.m. } \\
\text { electroporation }\end{array}$ & Single dose & $\begin{array}{l}10^{5} \text { PFU VEEV 3908, } \\
21 \text { dpim }\end{array}$ & s.c. & PRNT80, 10 to 320 & [174] \\
\hline WEEV & $\begin{array}{c}\text { pE3-E2-6K-E1 } \\
\text { pE3-E2 } \\
\text { P6K-E1 }\end{array}$ & $71 V-1658$ & $\begin{array}{l}\text { BALB/c, age } \\
\text { not specified }\end{array}$ & $2 \mu \mathrm{g}$ & gene gun & $\begin{array}{l}\text { Three doses } \\
\text { (14 days apart) }\end{array}$ & $\begin{array}{c}1500 \text { PFU WEEV } \\
\text { 71V-1658, } \\
\text { Fleming, or CBA87, } \\
42 \text { dpim }\end{array}$ & i.n. & ND & [175] \\
\hline \multirow{4}{*}{ CHIKV } & \multirow{4}{*}{$\begin{array}{l}\text { pCHIKV- } \\
\text { Capsid, } \\
\text { pCHIKV- } \\
\text { Envelope } \\
\text { (pMCE321) }\end{array}$} & \multirow{4}{*}{ Consensus } & $\begin{array}{l}\text { C57BL/ } 6 \text { mice, } 3 \\
\text { to } 4 \text { week old }\end{array}$ & $\begin{array}{c}25 \mu \mathrm{g} \\
2-3 \text { times }\end{array}$ & Electroporation & $\begin{array}{l}\text { Two doses } \\
\text { ( } 2 \text { weeks } \\
\text { apart) }\end{array}$ & ND & ND & ND & \multirow{4}{*}[176-178]{} \\
\hline & & & $\begin{array}{l}\text { C57BL } / 6 \text { mice, } 6 \\
\text { to } 8 \text { week old }\end{array}$ & $25 \mu \mathrm{g}$ & $\begin{array}{c}\text { i.m. } \\
\text { electroporation }\end{array}$ & $\begin{array}{l}\text { Three doses } \\
(0,14 \text { and } 21 \text { days })\end{array}$ & $\begin{array}{c}7 \log _{10} \text { PFU of PC-08, } \\
35 \mathrm{dpim}\end{array}$ & i.n. & NP & \\
\hline & & & BALB/c mice & $25 \mu \mathrm{g}$ & $\begin{array}{c}\text { i.m. } \\
\text { electroporation }\end{array}$ & $\begin{array}{c}\text { Two doses } \\
\text { (2 weeks apart) }\end{array}$ & $7 \log _{10}$ PFU PC-08 & i.n. & TCID50, 20 to 320 & \\
\hline & & & $\begin{array}{c}\text { Rhesus } \\
\text { macaques, age } \\
\text { not specified }\end{array}$ & $1 \mathrm{mg}$ & $\begin{array}{l}\text { i.m. } \\
\text { electroporation }\end{array}$ & $\begin{array}{l}\text { Three doses } \\
\text { (4 weeks apart) }\end{array}$ & ND & ND & TCID50, 80 to 1280 & \\
\hline CHIKV & $\begin{array}{l}\Delta 5 \mathrm{nsP3} \text { and } \\
\Delta 6 \mathrm{~K} \text { DNA }\end{array}$ & LR2006 OPY1 & $\begin{array}{l}\text { C57BL/ } 6 \text { mice, } 5 \\
\text { to } 6 \text { week old }\end{array}$ & $20 \mu \mathrm{g}$ & $\begin{array}{c}\text { i.d. with } \\
\text { DermaVax } \\
\text { electroporation }\end{array}$ & $\begin{array}{l}\text { Single dose or } \\
\text { two doses } \\
(0 \text { and } 3 \text { weeks })\end{array}$ & $\begin{array}{c}10^{6} \text { PFU LR2006 OPY1, } \\
7 \text { wpim }\end{array}$ & s.c. & NT50, 100 to 10000 & [131] \\
\hline
\end{tabular}


Table 1. Cont.

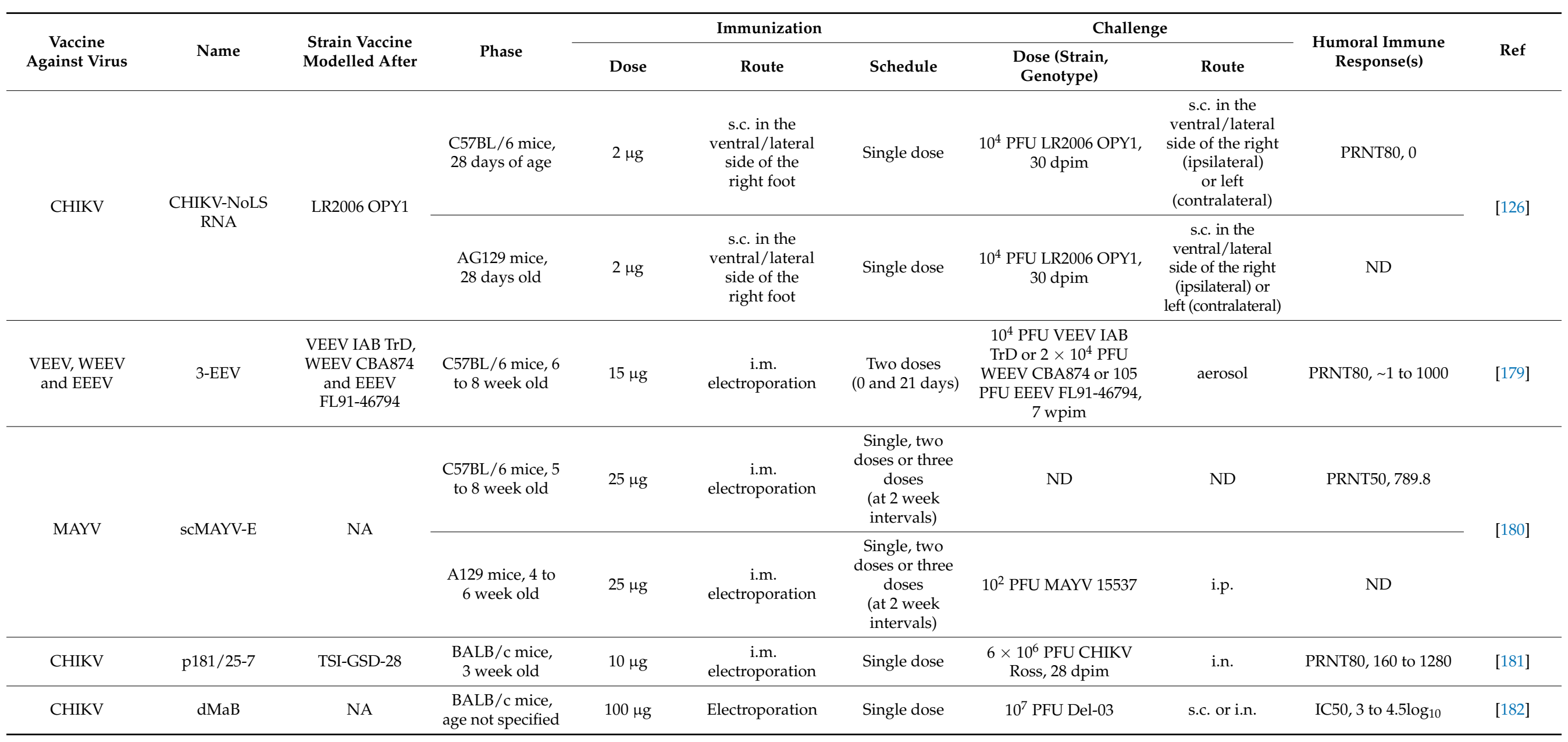


Table 1. Cont.

\begin{tabular}{|c|c|c|c|c|c|c|c|c|c|c|}
\hline \multirow{2}{*}{$\begin{array}{c}\text { Vaccine } \\
\text { Against Virus }\end{array}$} & \multirow[b]{2}{*}{ Name } & \multirow[b]{2}{*}{$\begin{array}{l}\text { Strain Vaccine } \\
\text { Modelled After }\end{array}$} & \multirow[b]{2}{*}{ Phase } & \multicolumn{3}{|c|}{ Immunization } & \multicolumn{2}{|c|}{ Challenge } & \multirow[b]{2}{*}{$\begin{array}{l}\text { Humoral Immune } \\
\text { Response(s) }\end{array}$} & \multirow[b]{2}{*}{ Ref } \\
\hline & & & & Dose & Route & Schedule & $\begin{array}{l}\text { Dose (Strain, } \\
\text { Genotype) }\end{array}$ & Route & & \\
\hline CHIKV & $\begin{array}{l}\text { iRNA } \triangle 5 \mathrm{nsP3} \\
\text { iDNA } \triangle 5 \mathrm{nsP3}\end{array}$ & LR2006 OPY1 & $\begin{array}{l}\text { C57BL/ } 6 \text { mice, } \\
8 \text { week old }\end{array}$ & $\begin{array}{l}0.125,1.25 \\
\text { or } 10 \mu \mathrm{g}\end{array}$ & $\begin{array}{l}\text { i.m. in the } \\
\text { gastrocnemius } \\
\text { muscle of the left } \\
\text { hind leg }\end{array}$ & Single dose & $\begin{array}{c}10^{6} \text { PFU LR2006 OPY1, } \\
5 \text { wpim }\end{array}$ & $\begin{array}{l}\text { s.c. at the dorsal } \\
\text { side of each } \\
\text { hind foot }\end{array}$ & NT50, $\sim 1$ to $10^{4}$ & [183] \\
\hline VEEV & $\begin{array}{l}\text { pMG4020 DNA } \\
\text { plasmid }\end{array}$ & TC-83 & $\begin{array}{l}\mathrm{BALB} / \mathrm{c}, 4 \text { to } \\
8 \text { week old }\end{array}$ & 0.5 or $5 \mathrm{ug}$ & $\begin{array}{c}\text { i.m. } \\
\text { electroporation }\end{array}$ & Single dose & $\begin{array}{l}10^{4} \text { PFU VEEV TrD, } \\
28 \text { dpim }\end{array}$ & s.c. & $\begin{array}{c}\text { PRNT80, } \\
320 \text { to }>1280\end{array}$ & [141] \\
\hline \multirow{3}{*}{ VEEV } & \multirow{3}{*}{$\begin{array}{l}\text { VEEV }_{\text {WT }} \\
\text { VEEV }_{\text {COCAP }} \\
\text { VEEV }_{C O}\end{array}$} & \multirow{3}{*}{ IAB $\operatorname{TrD}$} & $\begin{array}{l}\text { New Zealand } \\
\text { White rabbits, } \\
\text { age not specified }\end{array}$ & $\begin{array}{l}500 \mu \mathrm{g} \text { of } \\
\text { VEEV }_{\mathrm{CO}}\end{array}$ & $\begin{array}{l}\text { i.m. } \\
\text { electroporation }\end{array}$ & $\begin{array}{l}\text { Three doses } \\
(0,28 \text { and } \\
230 \text { days })\end{array}$ & ND & ND & $\begin{array}{c}\text { PRNT80, } 3 \log _{10} \text { to } \\
5 \log _{10}\end{array}$ & \multirow{3}{*}[184,185]{} \\
\hline & & & $\begin{array}{l}\text { Cynomolgus } \\
\text { macaques, age } \\
\text { not specified }\end{array}$ & $\begin{array}{l}50 \text { or } 500 \mu g \\
\text { of } \mathrm{VEEV}_{\mathrm{CO}}\end{array}$ & $\begin{array}{l}\text { i.m. } \\
\text { electroporation }\end{array}$ & $\begin{array}{l}\text { Two doses }(0 \\
\text { and } 56 \text { days) }\end{array}$ & $\begin{array}{c}3 \times 10^{8} \text { PFU VEEV } \\
\text { IAB } \operatorname{TrD}\end{array}$ & aerosol & $\begin{array}{l}\text { PRNT80, } 0.8 \log _{10} \\
\text { to } 3.5 \log 10\end{array}$ & \\
\hline & & & $\begin{array}{l}\text { Human clinical } \\
\text { trial, Phase } 1\end{array}$ & 0.5 or $2 \mathrm{mg}$ & $\begin{array}{l}\text { i.m. } \\
\text { electroporation or } \\
\text { i.d. } \\
\text { electroporation }\end{array}$ & $\begin{array}{l}\text { Three doses } \\
\text { (days 0, 28, } \\
\text { and 56) }\end{array}$ & NA & NA & $\begin{array}{l}\text { GMT PRNT80, } \\
7 \text { to } 78\end{array}$ & \\
\hline WEEV & $\begin{array}{c}\text { pVHX-671V- } \\
1658 \\
\text { pVHX-6 CBA87 } \\
\text { pVHX-6 Fleming } \\
\end{array}$ & $\begin{array}{l}\text { Fleming, CBA } \\
87 \text { or } 71 \mathrm{~V}-1658\end{array}$ & $\begin{array}{l}\text { BALB/c mice, } \\
\text { age not specified }\end{array}$ & $\begin{array}{l}2 \text { shots } \times 2.5 \mu \mathrm{g} \\
\text { precipi- } \\
\text { tated on } \\
0.5 \mathrm{mg} \text { gold }\end{array}$ & gene gun & $\begin{array}{c}\text { Four doses } \\
\text { (2 weeks apart) }\end{array}$ & $\begin{array}{c}1.5 \times 10^{3} \text { PFU WEEV } \\
\text { Fleming, CBA } 87 \text { or } \\
71 \mathrm{~V}-1658,8 \text { wpim }\end{array}$ & i.n. & ND & [186] \\
\hline $\begin{array}{l}\text { WEEV } \\
\text { and EEEV }\end{array}$ & LANAC E1ecto & $\begin{array}{l}\text { WEEV } \\
\text { McMillan }\end{array}$ & $\begin{array}{l}\text { CD-1 mice, } 4 \text { to } \\
6 \text { week old }\end{array}$ & $10 \mu \mathrm{g}$ & $\begin{array}{l}\text { s.c. injection } \\
\text { dorsal to the } \\
\text { cervical spine }\end{array}$ & $\begin{array}{c}\text { Two doses } \\
\text { (2 weeks apart) }\end{array}$ & $\begin{array}{c}10^{4} \text { PFU WEEV } \\
\text { McMillan, } \\
\text { Montana-64, or EEEV } \\
\text { Florida-93, } 4,5,9,11 \\
\text { or } 13 \text { wpim }\end{array}$ & i.n. or s.c. & PRNT50, $<40$ to 200 & [187] \\
\hline
\end{tabular}


Table 1. Cont.

\begin{tabular}{|c|c|c|c|c|c|c|c|c|c|c|}
\hline \multirow{2}{*}{$\begin{array}{c}\text { Vaccine } \\
\text { Against Virus }\end{array}$} & \multirow[b]{2}{*}{ Name } & \multirow{2}{*}{$\begin{array}{l}\text { Strain Vaccine } \\
\text { Modelled After }\end{array}$} & \multirow[b]{2}{*}{ Phase } & \multicolumn{3}{|c|}{ Immunization } & \multicolumn{2}{|c|}{ Challenge } & \multirow{2}{*}{$\begin{array}{l}\text { Humoral Immune } \\
\text { Response(s) }\end{array}$} & \multirow[b]{2}{*}{ Ref } \\
\hline & & & & Dose & Route & Schedule & $\begin{array}{l}\text { Dose (Strain, } \\
\text { Genotype) }\end{array}$ & Route & & \\
\hline CHIKV & $\begin{array}{l}\text { mRNA-1388 (or } \\
\text { VAL-181388 in } \\
\text { clinical trials) }\end{array}$ & NA & $\begin{array}{l}\text { Human clinical } \\
\text { trial, Phase } 1\end{array}$ & $\begin{array}{l}25,50 \text { or } \\
100 \mu \mathrm{g}\end{array}$ & i.m. & $\begin{array}{c}\text { Dose } \\
\text { escalation } \\
\text { procedure }(0 \\
\text { and } 4 \text { weeks })\end{array}$ & ND & ND & $\begin{array}{l}\text { 'dose-dependent } \\
\text { increase' in } \\
\text { neutralizing and } \\
\text { binding } \\
\text { antibody titers }\end{array}$ & [188] \\
\hline \multirow{3}{*}{ CHIKV } & \multirow{3}{*}{ mRNA-1944 } & \multirow{3}{*}{ SL15649 } & $\begin{array}{l}\text { AG129, age not } \\
\text { specified }\end{array}$ & $\begin{array}{c}0.4,1 \text { or } \\
10 \mathrm{mg} / \mathrm{kg}\end{array}$ & $\begin{array}{l}\text { i.v. tail vein } \\
\text { injection }\end{array}$ & Single dose & $10^{2.5}$ TCID50 of CHK & $\begin{array}{l}\text { subcutaneous } \\
\text { injection in the } \\
\text { footpad and } \\
\text { hock of the } \\
\text { right leg }\end{array}$ & ND & \multirow{3}{*}[189,190]{} \\
\hline & & & $\begin{array}{l}\text { Cynomolgus } \\
\text { macaques, } 2 \text { to } \\
3 \text { year old }\end{array}$ & $0.5 \mathrm{mg} / \mathrm{kg}$ & i.v. & Single dose & ND & ND & FRNT50, 5 to 12 & \\
\hline & & & $\begin{array}{c}\text { Human clinical } \\
\text { trial, Phase } 1 \\
\text { (active, not } \\
\text { recruiting) }\end{array}$ & $\begin{array}{c}0.1,0.3 \text { and } \\
0.6 \mathrm{mg} / \mathrm{kg}\end{array}$ & i.v. & $\begin{array}{c}\text { Dose } \\
\text { escalation }\end{array}$ & NA & NA & $\begin{array}{c}\text { NT50, 'all } \\
\text { participants also } \\
\text { showed circulating } \\
\text { neutralizing } \\
\text { antibody activity' }\end{array}$ & \\
\hline \multicolumn{11}{|l|}{ Subunit } \\
\hline CHIKV & $\begin{array}{l}\text { CHIKV-sE1 } \\
\text { and -sE2 }\end{array}$ & S27 & $\begin{array}{l}\text { AG129 mice, } \\
6 \text { week old }\end{array}$ & $2 \mu \mathrm{g}$ & s.c. & $\begin{array}{c}\text { Two doses } \\
\text { (0 and } 21 \text { days) }\end{array}$ & $\begin{array}{l}1000 \text { TCID50 of S27 } \\
\text { isolate, } 9 \text { wpim }\end{array}$ & i.p. & NT95, $<25$ & $\begin{array}{c}\text { [164,165, } \\
191]\end{array}$ \\
\hline CHIKV & $\mathrm{rE} 2 \mathrm{p}$ & IND-06-AP3 & $\begin{array}{l}\text { BALB } / \mathrm{c}, 6 \text { to } \\
8 \text { week old }\end{array}$ & $\begin{array}{c}10,20 \text { or } 50 \\
\mu \mathrm{g}\end{array}$ & i.m. & $\begin{array}{c}\text { Two doses } \\
\text { (2 weeks apart) }\end{array}$ & $\begin{array}{l}\text { Mice immunized with } \\
50 \mu \mathrm{g} \text { challenged with } \\
7 \text { log10 TCID } 50 / \mathrm{mL} \\
4 \text { or } 22 \text { wpim }\end{array}$ & i.n. & $\begin{array}{c}\text { NT50, } 0.25 \log 10 \text { to } \\
2.5 \log 10\end{array}$ & [154] \\
\hline CHIKV & $\begin{array}{l}\text { CHIKE1 and } \\
\text { CHIKE2 } \\
\text { recombinant } \\
\text { proteins }\end{array}$ & DRDE-06 & $\mathrm{BALB} / \mathrm{c}$ & $40 \mu \mathrm{g}$ & s.c. & $\begin{array}{c}\text { Three doses }(0, \\
21 \text { and } \\
35 \text { days })\end{array}$ & ND & ND & PRNT90, 32 to 512 & [192] \\
\hline
\end{tabular}


Table 1. Cont.

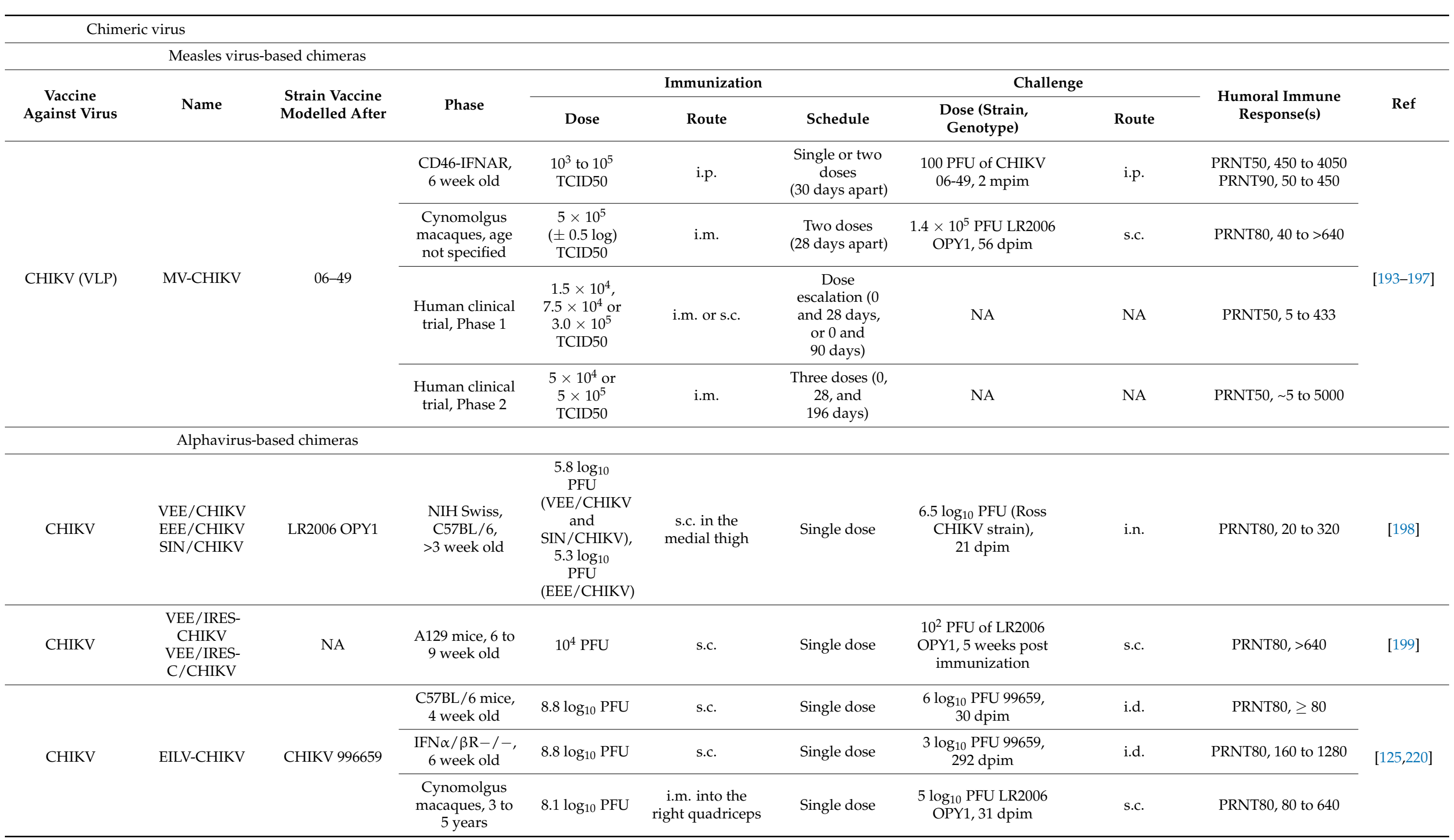


Table 1. Cont.

\begin{tabular}{|c|c|c|c|c|c|c|c|c|c|c|}
\hline \multirow{2}{*}{$\begin{array}{c}\text { Vaccine } \\
\text { Against Virus }\end{array}$} & \multirow[b]{2}{*}{ Name } & \multirow{2}{*}{$\begin{array}{l}\text { Strain Vaccine } \\
\text { Modelled After }\end{array}$} & \multirow[b]{2}{*}{ Phase } & \multicolumn{3}{|c|}{ Immunization } & \multicolumn{2}{|c|}{ Challenge } & \multirow{2}{*}{$\begin{array}{c}\text { Humoral Immune } \\
\text { Response(s) }\end{array}$} & \multirow[b]{2}{*}{ Ref } \\
\hline & & & & Dose & Route & Schedule & $\begin{array}{l}\text { Dose (Strain, } \\
\text { Genotype) }\end{array}$ & Route & & \\
\hline EEEV & EILV/EEEV & EEEV FL-93 & $\begin{array}{l}\text { Adult CD-1 } \\
\text { mice (age } \\
\text { not specified) }\end{array}$ & $10^{8} \mathrm{PFU}$ & s.c. & Single dose & $\begin{array}{l}10^{5} \text { PFU EEEV-FL93, } \\
70 \text { dpim }\end{array}$ & i.p. & PRNT80, 80 to 640 & \multirow{4}{*}[125,220]{} \\
\hline EEEV & $\begin{array}{c}\text { Trivalent } \\
\text { EILV/EEEV } \\
\text { EILV/VEEV } \\
\text { EILV/CHIKV }\end{array}$ & $\begin{array}{c}\text { EEEV FL-93, } \\
\text { VEEV IAB } \\
\text { TC-83, CHIKV } \\
996659\end{array}$ & $\begin{array}{l}\text { Adult CD-1 } \\
\text { mice (age not } \\
\text { specified) }\end{array}$ & $10^{8} \mathrm{PFU}$ & s.c. & Single dose & $\begin{array}{l}10^{5} \text { PFU EEEV-FL93, } \\
70 \text { dpim }\end{array}$ & i.p. & $\begin{array}{l}\text { PRNT80, } 40 \text { to } 640 \\
\text { and } 20 \text { to } 640 \text { for } \\
\text { mono- and trivalent } \\
\text { vaccines respectively }\end{array}$ & \\
\hline VEEV & EILV / EEEV & $\begin{array}{l}\text { VEEV IAB } \\
\text { TC-83 }\end{array}$ & $\begin{array}{l}\text { Adult CD-1 } \\
\text { mice (age not } \\
\text { specified) }\end{array}$ & $10^{8} \mathrm{PFU}$ & s.c. & Single dose & $\begin{array}{l}10^{3} \text { PFU VEEV-IC } \\
\text { 3908, } 70 \text { dpim }\end{array}$ & s.c. & PRNT80, 80 to 1280 & \\
\hline VEEV & $\begin{array}{c}\text { Trivalent } \\
\text { EILV/EEEV, } \\
\text { EILV/VEEV } \\
\text { EILV/CHIKV }\end{array}$ & $\begin{array}{l}\text { EEEV FL-93, } \\
\text { VEEV IAB } \\
\text { TC-83, CHIKV } \\
996659\end{array}$ & $\begin{array}{l}\text { Adult CD-1 } \\
\text { mice (age not } \\
\text { specified) }\end{array}$ & $10^{8} \mathrm{PFU}$ & s.c. & Single dose & $\begin{array}{l}10^{3} \text { PFU VEEV-IC } \\
3908,70 \text { dpim }\end{array}$ & s.c. & $\begin{array}{l}\text { PRNT80, } 40 \text { to } 640 \\
\text { and } 20 \text { to } 80 \text { for } \\
\text { mono- and trivalent } \\
\text { vaccines respectively }\end{array}$ & \\
\hline $\begin{array}{c}\text { EEEV } \\
\text { (Sindbis virus) }\end{array}$ & SIN/NAEEEV & EEEV FL93-939 & $\begin{array}{l}\text { NIH Swiss mice, } \\
8 \text { week old }\end{array}$ & $\begin{array}{c}\text { 3.7, } 4.7 \text { or } \\
5.7 \log _{10} \text { PFU }\end{array}$ & s.c. & Single dose & $\begin{array}{c}6 \log _{10} \text { PFU FL93-939, } \\
28 \text { dpim }\end{array}$ & i.p. & PRNT80, 125 to 660 & [200] \\
\hline \multirow{6}{*}{ VEEV } & \multirow{2}{*}{ SIN-83 } & \multirow{2}{*}{$\begin{array}{l}\text { VEEV IAB } \\
\text { TC-83 }\end{array}$} & $\begin{array}{l}\text { Weanling NIH } \\
\text { Swiss mice, } \\
6 \text { day old }\end{array}$ & $\begin{array}{l}10^{3}, 10^{4}, 10^{5} \\
\text { or } 10^{6} \mathrm{PFU}\end{array}$ & s.c. & Single dose & $\begin{array}{c}10^{6} \text { PFU VEEV IC } \\
\text { ZPC738 IC SH3 }\end{array}$ & $\begin{array}{c}\text { s.c.in } \\
\text { medial thigh }\end{array}$ & PRNT80, 30 to 960 & \multirow{6}{*}[201,202]{} \\
\hline & & & $\begin{array}{l}\text { NIH Swiss mice, } \\
6 \text { week old }\end{array}$ & $5 \times 10^{5} \mathrm{PFU}$ & s.c. & Two doses & $\begin{array}{c}2 \times 10^{5} \text { or } 10^{6} \mathrm{PFU} \\
\text { VEEV ZPC738, } 8 \text { wpim }\end{array}$ & s.c., i.c., or i.n. & $\begin{array}{l}\text { PRNT80, } 55 \text { to } 73 \\
\text { (single), } 100 \text { to } \\
160 \text { (booster) }\end{array}$ & \\
\hline & SAAR/TRD & VEEV IAB TrD & $\begin{array}{l}\text { NIH Swiss mice, } \\
6 \text { week old }\end{array}$ & $5 \times 10^{5} \mathrm{PFU}$ & s.c. & Two doses & $\begin{array}{c}2 \times 10^{5} \text { or } 10^{6} \mathrm{PFU} \\
\text { VEEV ZPC738, } 8 \text { wpim }\end{array}$ & s.c., i.c., or i.n. & $\begin{array}{l}\text { PRNT80, } 126 \text { to } 167 \\
\text { (single), } 152 \text { to } \\
160 \text { (booster) }\end{array}$ & \\
\hline & $\mathrm{SIN} / \mathrm{TRD}$ & VEEV IAB TrD & $\begin{array}{l}\text { NIH Swiss mice, } \\
6 \text { week old }\end{array}$ & $5 \times 10^{5} \mathrm{PFU}$ & s.c. & Two doses & $\begin{array}{c}2 \times 10^{5} \text { or } 10^{6} \mathrm{PFU} \\
\text { VEEV ZPC } 738,8 \text { wpim }\end{array}$ & s.c., i.c., or i.n. & $\begin{array}{l}\text { PRNT80, } 37 \text { to } 57 \\
\text { (single), } 50 \text { to } \\
73 \text { (booster) }\end{array}$ & \\
\hline & $\mathrm{SIN} / \mathrm{ZPC}$ & $\begin{array}{l}\text { VEEV ID } \\
\text { ZPC738 }\end{array}$ & $\begin{array}{l}\text { NIH Swiss mice, } \\
6 \text { week old }\end{array}$ & $5 \times 10^{5} \mathrm{PFU}$ & s.c. & Two doses & $\begin{array}{c}2 \times 10^{5} \text { or } 10^{6} \mathrm{PFU} \\
\text { VEEV ZPC738, } 8 \text { wpim }\end{array}$ & s.c., i.c., or i.n. & $\begin{array}{l}\text { PRNT80, } 187 \text { to } 253 \\
\text { (single), } 253 \text { to } \\
487 \text { (booster) }\end{array}$ & \\
\hline & All the above & $\begin{array}{c}\text { VEEV IAB } \\
\text { TC-83, IAB TrD, } \\
\text { ID ZPC738 }\end{array}$ & $\begin{array}{l}\text { Syrian golden } \\
\text { hamsters, } \\
6 \text { week old }\end{array}$ & $5 \times 10^{5} \mathrm{PFU}$ & $\begin{array}{l}\text { s.c. in the } \\
\text { medial thigh }\end{array}$ & Single dose & $10^{6} \mathrm{PFU}$ & $\begin{array}{l}\text { s.c.in } \\
\text { medial thigh }\end{array}$ & ND & \\
\hline
\end{tabular}


Table 1. Cont.

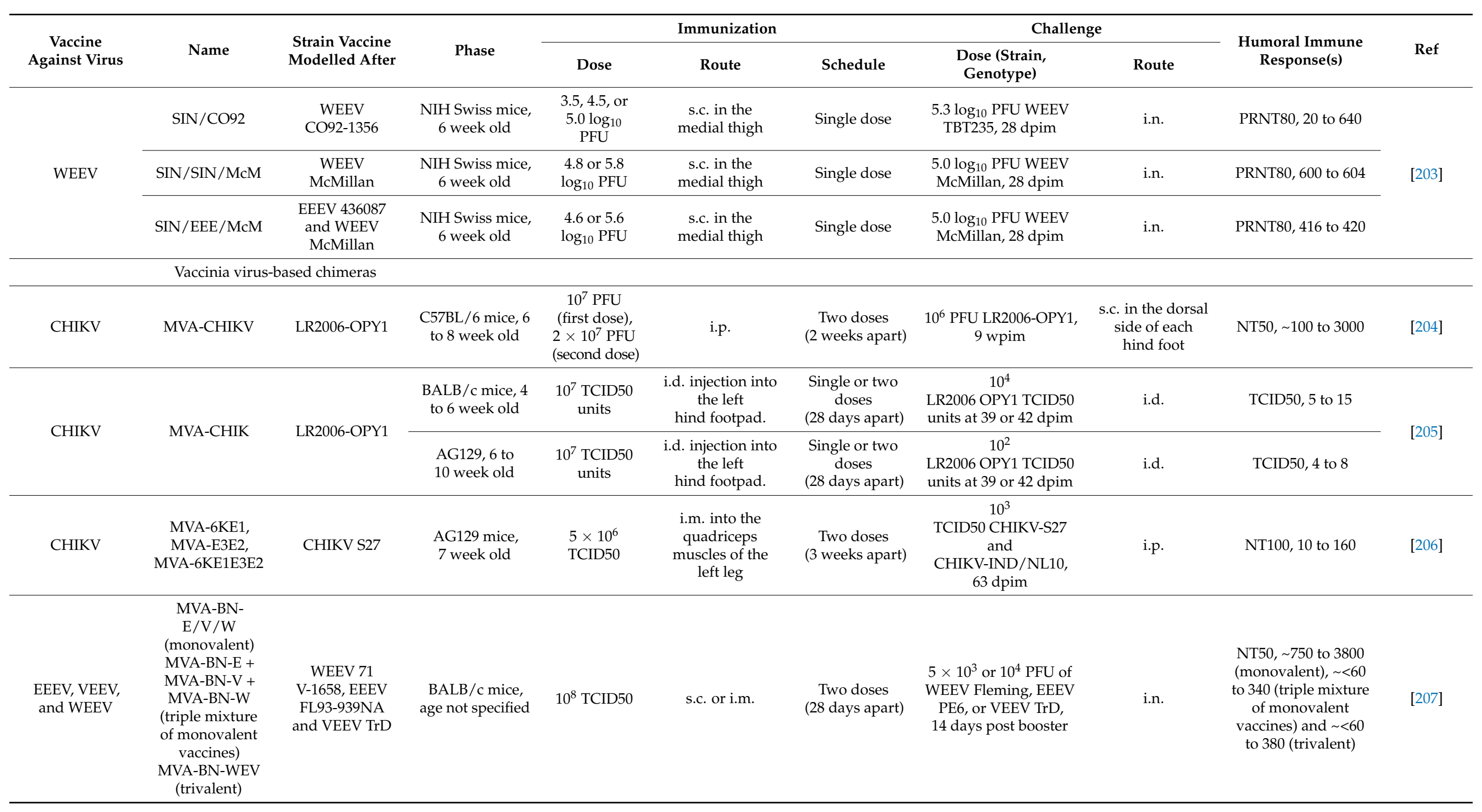


Table 1. Cont.

\begin{tabular}{|c|c|c|c|c|c|c|c|c|c|c|}
\hline \multirow{2}{*}{$\begin{array}{c}\text { Vaccine } \\
\text { Against Virus }\end{array}$} & \multirow[b]{2}{*}{ Name } & \multirow{2}{*}{$\begin{array}{l}\text { Strain Vaccine } \\
\text { Modelled After }\end{array}$} & \multirow[b]{2}{*}{ Phase } & \multicolumn{3}{|c|}{ Immunization } & \multicolumn{2}{|c|}{ Challenge } & \multirow[b]{2}{*}{$\begin{array}{l}\text { Humoral Immune } \\
\text { Response(s) }\end{array}$} & \multirow[b]{2}{*}{ Ref } \\
\hline & & & & Dose & Route & Schedule & $\begin{array}{l}\text { Dose (Strain, } \\
\text { Genotype) }\end{array}$ & Route & & \\
\hline \multicolumn{11}{|c|}{ Adenovirus-based chimeras } \\
\hline CHIKV & CAdVax-CHIK & LR2006 OPY1 & $\begin{array}{c}\text { CD- } 1 \text { or } \\
\text { C57BL/ } 6,6 \text { to } \\
8 \text { week old }\end{array}$ & $10^{8} \mathrm{IU}$ & i.p. & Single dose & $\begin{array}{c}10^{4} \text { CCID50 LR2006 } \\
\text { OPY1 or QIMR, } \\
6.5 \text { wpim }\end{array}$ & $\begin{array}{l}\text { s.c. into side of } \\
\text { each hind foot } \\
\text { towards } \\
\text { the ankle }\end{array}$ & NT100, 2000 & [208] \\
\hline \multirow[t]{4}{*}{ CHIKV } & \multirow{2}{*}{ ChAdOx1 Chik } & \multirow{4}{*}{ NA } & $\begin{array}{l}\text { BALB } / \mathrm{c}, 6 \text { to } \\
8 \text { week old }\end{array}$ & $10^{8} \mathrm{IU}$ & i.m. & Single dose & ND & ND & NT50, $5.39 \times 10^{3}$ & \multirow{2}{*}{209,210} \\
\hline & & & $\begin{array}{c}\text { AG129, } \\
5 \text { week old }\end{array}$ & $10^{8} \mathrm{IU}$ & i.m. in each leg & Single dose & $\begin{array}{c}9.7 \times 10^{4} \text { PFU LR2006 } \\
\text { OPY1, } 30 \text { dpim }\end{array}$ & $\begin{array}{l}\text { i.d. into the } \\
\text { left foot }\end{array}$ & ND & \\
\hline & $\begin{array}{c}\text { ChAdOx1 Chik } \\
\text { ChAdOx1 Chik } \\
\Delta \text { Cap }\end{array}$ & & $\begin{array}{c}\text { AG129, } \\
5 \text { week old }\end{array}$ & $10^{8} \mathrm{IU}$ & $\begin{array}{l}\text { i.m. in each } \\
\text { hind leg }\end{array}$ & Single dose & $\begin{array}{c}9.7 \times 10^{4} \text { PFU of } \\
\text { LR2006 OPY1, } 30 \text { dpim }\end{array}$ & $\begin{array}{l}\text { i.d. into the left } \\
\text { foot towards } \\
\text { the ankle }\end{array}$ & $\begin{array}{l}\text { PRNT80, } 32 \text { to } 64 \\
\text { (Chik), } 16 \text { to } 32 \\
\text { (Chik } \Delta \text { Cap) }\end{array}$ & [211] \\
\hline & $\begin{array}{l}\text { CHIK001 (in } \\
\text { clinical trials) }\end{array}$ & & $\begin{array}{l}\text { Human clinical } \\
\text { trial, Phase } 1\end{array}$ & $\begin{array}{c}5 \times 10^{9} \\
2.5 \times 10^{10} \\
\quad \text { or } \\
5 \times 10^{10} \mathrm{vp}\end{array}$ & i.m. & Single dose & ND & ND & ND & [212] \\
\hline \multirow{2}{*}{ VEEV } & \multirow{2}{*}{ Rad/VEEV\#3 } & \multirow{2}{*}{$\begin{array}{l}\text { VEEV IAB } \\
\text { TC-83 }\end{array}$} & $\begin{array}{l}\text { BALB } / \mathrm{c}, 6 \text { to } \\
8 \text { week old }\end{array}$ & $10^{7} \mathrm{PFU}$ & i.n. & $\begin{array}{l}\text { Three doses } \\
\text { (at } 0,7 \text { and } \\
21 \text { days) }\end{array}$ & Dose ND, 28 dpim & aerosol & PRNT50 (NP) & [213] \\
\hline & & & $\begin{array}{l}\text { BALB } / \mathrm{c}, 6 \text { to } \\
8 \text { week old }\end{array}$ & $10^{7} \mathrm{PFU}$ & i.n. & $\begin{array}{c}\text { Two doses } \\
\text { (at } 0,21 \text { days) }\end{array}$ & $\begin{array}{l}5000 \text { LD50 TrD, } \\
42 \text { dpim }\end{array}$ & aerosol & ND & [214] \\
\hline WEEV & Ad5-WEEV & WEEV 71V-1658 & $\begin{array}{l}\text { BALB/c mice, } \\
\text { age not specified }\end{array}$ & $10^{7} \mathrm{PFU}$ & i.m. & $\begin{array}{l}\text { Single or two } \\
\text { doses } \\
\text { (at } 4 \text { weeks) }\end{array}$ & $\begin{array}{l}1.5 \times 10^{3} \text { PFU Fleming } \\
\text { or } 71 \mathrm{~V}-1658,13 \text { wpim }\end{array}$ & i.n. & PRNT50, 160 & [215] \\
\hline \multirow[t]{2}{*}{ WEEV } & Ad5-E1 & WEEV 71V-1658 & $\begin{array}{l}\text { BALB/c mice, } 6 \\
\text { to } 9 \text { week old }\end{array}$ & $10^{7} \mathrm{PFU}$ & i.m. in both leg & Single dose & $\begin{array}{l}50 \text { LD50 of } 71 \mathrm{~V}-1658 \\
7 \text { dpim, or } \\
400 \text { LD50 CBA87, 1, 3, } \\
5 \text { or } 7 \text { dpim }\end{array}$ & i.n. & PRNT50, $<10$ & [216] \\
\hline & \multicolumn{2}{|c|}{ Vesiculovirus-based chimeras } & & & & & & & & \\
\hline CHIKV & $\begin{array}{l}\text { rVSV } \Delta G- \\
\text { CHIKV }\end{array}$ & CHIKV S27 & $\begin{array}{l}\text { C57BL } / 6 \text {, } \\
3 \text { week old }\end{array}$ & $10^{6} \mathrm{PFU}$ & $\begin{array}{l}\text { i.m. into the right } \\
\text { hind leg muscle }\end{array}$ & Single dose & $\begin{array}{l}10^{4} \text { PFU LR } 2006 \\
\text { OPY1, } 30 \text { dpim }\end{array}$ & $\begin{array}{l}\text { s.c. in the left } \\
\text { rear footpad }\end{array}$ & PRNT80, 80 to 640 & [217] \\
\hline
\end{tabular}


Table 1. Cont.

\begin{tabular}{|c|c|c|c|c|c|c|c|c|c|c|}
\hline \multirow{2}{*}{$\begin{array}{c}\text { Vaccine } \\
\text { Against Virus }\end{array}$} & \multirow[b]{2}{*}{ Name } & \multirow{2}{*}{$\begin{array}{l}\text { Strain Vaccine } \\
\text { Modelled After }\end{array}$} & \multirow[b]{2}{*}{ Phase } & \multicolumn{3}{|c|}{ Immunization } & \multicolumn{2}{|c|}{ Challenge } & \multirow{2}{*}{$\begin{array}{c}\text { Humoral Immune } \\
\text { Response(s) }\end{array}$} & \multirow[b]{2}{*}{ Ref } \\
\hline & & & & Dose & Route & Schedule & $\begin{array}{l}\text { Dose (Strain, } \\
\text { Genotype) }\end{array}$ & Route & & \\
\hline VEEV & rVSIV-VEEV & VEEV ZPC738 & $\begin{array}{l}\text { CD- } 1,4 \text { to } \\
6 \text { week old }\end{array}$ & $10^{8} / 10^{7} \mathrm{PFU}$ & i.m. & Single dose & $\begin{array}{c}10^{4} \text { PFU VEEV } \\
\text { ZPC738, } 35 \text { or } \\
245 \text { dpim }\end{array}$ & s.c. & $\begin{array}{l}\text { PRNT80, } 288 \text { to } 600 \\
\text { at } 25 \text { and } 35 \mathrm{dpim}, \\
304 \text { to } 360 \text { at } \\
245 \mathrm{dpim}\end{array}$ & \multirow{3}{*}[218]{} \\
\hline VEEV & rISFV-VEEV & VEEV ZPC738 & $\begin{array}{l}\text { CD-1, } 4 \text { to } \\
6 \text { week old }\end{array}$ & $10^{8} \mathrm{PFU}$ & i.m. & Single dose & $\begin{array}{c}10^{4} \text { PFU VEEV } \\
\text { ZPC738, } 28 \text { dpim }\end{array}$ & s.c. & PRNT80, $\geq 20$ & \\
\hline EEEV & rISFV-EEEV & EEEV FL93-939 & $\begin{array}{l}\text { CD-1, } 4 \text { to } \\
6 \text { week old }\end{array}$ & $10^{8} \mathrm{PFU}$ & i.m. & Single dose & $\begin{array}{c}10^{4} \text { PFU EEEV } \\
\text { FL93-939, } 28 \text { dpim }\end{array}$ & s.c. & PRNT80, $\geq 20$ & \\
\hline \multicolumn{11}{|c|}{ Epitope-based } \\
\hline CHIKV & E2EP3 & NA & $\begin{array}{l}\text { C57BL/ } 6 \text { mice, } \\
3 \text { week old }\end{array}$ & $\begin{array}{c}100 \\
\mu \mathrm{g}(50 \mu \mathrm{g} \text { for } \\
\text { booster doses })\end{array}$ & $\begin{array}{l}\text { s.c. in the } \\
\text { abdominal flank }\end{array}$ & $\begin{array}{l}\text { Three doses } \\
\text { (0, } 14 \text { and } \\
21 \text { days) }\end{array}$ & $\begin{array}{l}10^{6} \text { PFU CHIKV } \\
\text { SGP11, } 30 \text { dpim }\end{array}$ & $\begin{array}{l}\text { s.c. region at the } \\
\text { ventral side of } \\
\text { the right hind } \\
\text { footpad, } \\
\text { towards } \\
\text { the ankle }\end{array}$ & $\begin{array}{l}\sim 40 \% \text { reduction } \\
\text { from mock control }\end{array}$ & [23] \\
\hline
\end{tabular}

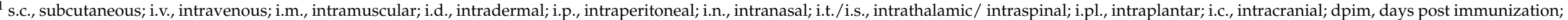

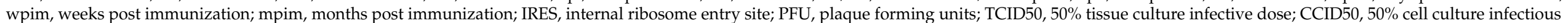

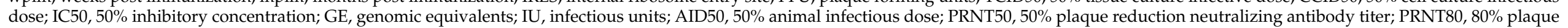

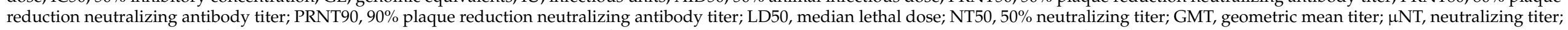

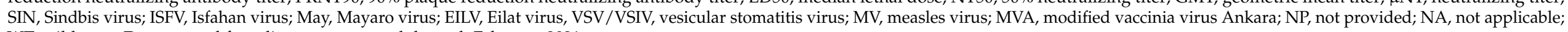
WT, wild type. Data curated from literature reported through February 2021 


\subsection{Live-Attenuated Vaccines}

With the development of alphaviruses in reverse genetic systems, more research has been focused on the rational design of live-attenuated vaccines [221,222] in overcoming potential issues, such as genetic reversion mutations in vaccines $[223,224]$, with highly specific mutations or alterations of the original parental virus genome. In addition, not only are the safety profiles of these vaccines is greatly improved, protection with a only single dose is also achieved [225].

An engineered live-attenuated option for alphavirus vaccine design involves the rational design of downregulating the expression of particular structural proteins with the introduction of a picornavirus (encephalomyocarditis virus) internal ribosome entry site (IRES) into the viral genome. For example, this is demonstrated in a VEEV vaccine candidate, ZPC/IRES, where the expression of the capsid protein is minimalized by translocating its gene to a separate opening reading frame downstream of the envelope glycoprotein genes and interrupting its expression with the introduction of a IRES $[114,226]$. However, the highly immunogenic envelope glycoproteins E3-E1 were not manipulated, but the insertion of IRES into the genome would functionally alter the host range as replication of the live virus is restricted in mosquitoes.

ZPC/IRES is based on a full-length clone of a wild type VEEV subtype ID from Zulia state, Venezuela from a sentinel hamster exposed in a tropical lowland. CD-1 mice immunized with $10^{5} \mathrm{PFU}$ of ZPC/IRES developed strongly neutralizing antibodies, with PRNT80 of average reciprocal titer of 324 by 20 weeks post immunization. Subsequently, when immunized mice were challenged with the lethal VEEV subtype IC strain 3908 ( $10^{5} \mathrm{PFU}$, subcutaneous or $10^{4} \mathrm{PFU}$, aerosol route) 4 weeks after immunization, all mice retained their weight and failed to show any signs of disease and survived, compared to mock-vaccinated mice which succumbed to the lethal infection. Additionally, the study tested the vaccine in a NHP immunization-challenge model in the same study. Vaccinated NHPs had PRNT80 values of 160 to 320, and all vaccinated NHPs were protected against viremia upon challenge with VEEV 3908 strain. Using the VEEV ID strain ZPC738 as the vaccine backbone, which is closely related to subtypes IAB and IC, the authors had aimed to develop an IRES-based, live-attenuated vaccine candidate that could possibly protect against other subtypes of $\mathrm{VEEV}$, given that previous attempts to create a vaccine candidate based on the VEEV subtype IAB V3526 vaccine could not significantly protect against aerosol challenge with a subtype IE VEEV strain [226]. Nonetheless, this hypothesis was not pursued in the study, and it would have been curious to learn whether the ZPC/IRES-immunized animals would be protected from a lethal challenge with VEEV of other subtypes, such as subtypes IA/B and IE.

\subsection{Inactivated Vaccines}

The inactivated Ross River virus (RRV) vaccine is the most developed and advanced vaccine candidate, having been rigorously tested in both preclinical and up to Phase 3 clinical trials. The Vero cell culture-derived whole-virus RRV vaccine was first produced from a viral seed derived from an RRV isolate from a serologically confirmed case of RRV disease in Queensland, Australia, and subsequently inactivated by sequential formalin and UV light treatment after harvest [227]. In pre-clinical testing of the RRV vaccine, CD-1 mice were given two doses of the inactivated RRV vaccines at different experimental doses 28 days apart, without the use of an adjuvant in its formulation. Upon challenge with $10^{6}$ TCID50 of the mouse-virulent RRV prototype strain T48 at 42 days post immunization, a vaccine dose beyond $0.625 \mu \mathrm{g}$ provided almost complete protection against viremia development at 1-day post challenge. Interestingly, the possible antibody-dependent enhancement by RRV vaccination by a closely related alphavirus infection was investigated, where viremia in CHIKV LR2006 OPY-1-infected-RRV vaccinated mice was significantly reduced as compared to the control. In this heterologous situation, partial cross protection was observed, but the presence of sub-protective levels of RRV vaccine-induced antibodies prevented the enhancement of CHIKV replication [73]. 
Subsequently, a randomized Phase 3 clinical trial for the RRV vaccine was conducted in Australia to investigate the safety and immunogenicity of the vaccine in a large cohort of 1755 healthy younger adults aged 16 to 59 years and 209 healthy older adults aged $>60$ years [115]. The $2.5 \mu \mathrm{g} \mathrm{Al}(\mathrm{OH}) 3$-adjuvanted vaccine was given over three doses (subsequent boosts at 3 weeks and 6 months). The majority of participants in the younger and older adult populations had seroprotective uNT titers after three immunizations with the whole-virus RRV vaccine, and titers of serum IgG antibodies after three immunizations were higher than the serological IgG ELISA titer threshold associated with protection after natural infection with RRV [115]. While the RRV vaccine had been brought forward to Phase 3 clinical trials, and despite the vaccine demonstrating safety and efficacy, it was not considered financially viable to manufacture, despite Queensland recording its largest and worst epidemic between 2014 to 2015 [228,229]. In addition, given that the cost of vaccine trials is hard to justify for a disease that occurs only in Australia and Papua New Guinea, and where the disease is never fatal, efforts to further develop the RRV vaccine were unfortunately halted.

\subsection{Virus-Like Particles (VLPS)}

The VRC-CHKVLP059-00-VP is one of the first potential new CHIKV vaccines to reach advanced development with human clinical testing $[116,117]$. The CHIKV envelope gene cassette encoding the native polypeptide, E3-E2-6K-E1, of CHIKV strains 37,997 (West African genotype) and LR2006 OPY-1 were inserted into a cytomegalovirus CMV/R expression vector and subsequently transfected into 293T human kidney cells [118]. The resulting VLP product is a CHIKV VLP that is structurally identical to its infectious counterpart (given that structural genes are intact), but is not infectious as its genetic material is removed. While the CHIKV 37997 strain yielded approximately 100 times more VLPs than that from strain LR2006 OPY-1, the former strain was subsequently used to produce the VLPs. Nonetheless, given that the ECSA lineage was responsible for the ongoing outbreak at the time of development, the high degree of amino acid similarity between the two CHIKV strains suggested that the vaccine would be protective against viruses of other genotypes. However, it would have been curious to characterize a VLP produced from a CHIKV strain of the ECSA lineage, given that it is the strain responsible for recent Chikungunya epidemics all around the world [119-123].

BALB/c mice immunized with two doses of $19 \mu \mathrm{g}$ of CHIKV VLPs intramuscularly generated the highest neutralizing titer against both the homologous strain 37,997 and the heterologous strain LR2006 OPY-1. In addition, NHPs immunized with $20 \mu \mathrm{g}$ of VLPs developed substantial neutralizing activity to both homologous and heterologous strains after primary immunization. Interestingly, even though the VLP was made from CHIKV 27,997 strain, there was slightly better neutralization of LR2006 OPY-1 compared to 37,997 in both mice and NHPs. The study speculated that this is suggestive that the LR2006 OPY-1 virus may present a conserved epitope to the immune system better than the 37,997 virus. When total IgG antibodies were passively transferred from immunized NHPs to defective type 1 interferon signaling immunodeficient mice $\left(\operatorname{Ifnar} 1^{-/-}\right)$, these recipient mice did not develop detectable viremia and all survived a lethal challenge with CHIKV LR2006 OPY-1. This indicated that the humoral immune responses induced by the CHIKV VLPs confer protection against CHIKV infection [124].

This promising data eventually led to further testing in clinical trials-phase 2 studies were concluded and reported in 2020 [117]. The randomized phase 2 clinical trial included 400 healthy adults in outpatient clinics in 6 countries in the Caribbean. Two doses of $20 \mu \mathrm{g}$ of CHIKV VLP, termed as VRC-CHKVLP059-00-VP in clinical trials, were administered 28 days apart via intramuscular injection. Vaccine-induced humoral immune responses in individuals were comparable with titers from participants vaccinated in the phase 1 trial [116], and serum collected from participants in the phase 1 trial induced neutralizing antibodies against all 3 genotypes of CHIKV. Interestingly, while the phase 2 trial aimed to only enroll CHIKV seronegative participants, $20 \%$ of the cohort (in particular, participants 
from 2 study sites-Dominican Republic and Haiti) were retrospectively found to be seropositive at baseline on the day of the study enrolment, possibly due to seroconversion between screening and study enrolment. A post-hoc analysis demonstrated that the VLP was immunogenic among these seropositive recipients, but a significant difference was observed between the geometric mean ratio between seropositive and seronegative vaccine recipients. Further studies on this specific group of participants to understand the possible effects of seropositivity and efficacy or protection of the CHIKV VLP administered will be interesting, rendering the need for additional clinical trials [117].

\subsection{Chimeric Viruses}

Another option in vaccine development in providing high levels of immunity is the use of a virus-vector system that utilizes an avirulent backbone, but incorporates the expression of viral genetic elements, such as the chimeric vector system for producing foreign gene products.

The insect-only host-restricted Eilat virus (EILV) has recently also been utilized as a chimeric backbone to replace the structural open reading frame with that of EEEV, VEEV or CHIKV [125]. Given that EILV is unable to replicate in vertebrate cells and in brain tissues of infant mice, this enhances the safety aspect of the vaccine, and thus, also serves as a inactivated vaccine, which enhances the expression of particular immunogenic proteins. Separately, the monovalent EILV / EEEV and EILV/VEEV vaccines were efficacious in their protection against lethal alphavirus challenge-immunized CD-1 mice had a high seroconversion rate observed post vaccination and were highly protected from lethal EEEV-FL93 or VEEV-3908 challenge. Compared to mock-vaccinated animals, EILV/EEEV or EILV/VEEV immunized animals had little or no weight loss and were protected from disease. More importantly, a trivalent vaccine containing the EILV/EEEV, EILV/VEEV and EILV/CHIKV chimeras was formulated and assessed if the vaccine could provide protection against lethal challenge with multiple alphaviruses. A single trivalent dose of EILV/VEEV, EILV/EEEV, and EILV / CHIKV elicited neutralizing antibodies against all three viruses and provided $>80 \%$ protection against VEEV and EEEV lethal challenge. Collectively, this work showed safety combined with strong immunogenicity and ease of production, making the use of the EILV alphavirus chimeric vaccine platform promising and attractive [125]. The use of a trivalent vaccine candidate also serves as a proof-of-concept to show practicality and increases its potential as a vaccine against neurotropic alphaviruses.

\subsection{Nucleic Acid-Based Vaccines}

Commonly known as the 'third-generation vaccine', RNA and DNA vaccines form one of the latest vaccine approaches for alphaviruses. The risk of infection from receiving a vaccine is minimal, given the safety associated with the nucleic acid product [230]. In addition, as some vaccines have been shown to have poor immunogenicity due to the lack of uptake or the need for adjuvants [231], much research over the past decades have explored the design of constructs and novel delivery technologies to overcome these issues. In order to overcome several issues related to traditional vaccine development, such as high cost and difficulty in production, RNA has emerged as an effective platform to deliver vaccines using nanoparticle delivery vehicles, such as liposomes [232-234].

A RNA vaccine against CHIKV involves the delivery of the self-replicating RNA genome of the live attenuated CHIKV-NoLS virus with CAF01 liposomes [126]. The mutation in the nucleolar localization sequence (NoLS) in the capsid protein of CHIK-NoLS was previously shown to significantly attenuate viral replication [127]. In the same study, C57/BL6 mice immunized with one dose of CHIKV-NoLS were fully protected from CHIKV infection [127]. In immunodeficient AG129 mice, a single dose of CHIKV-NoLS RNA delivered with CAF01 generated CHIKV-specific neutralizing antibodies. While these immunized AG129 mice developed disease signs, they eventually recover from the immunization, compared to mock-immunized mice. Importantly, CHIKV-NoLS CAF01immunized AG129 mice survive from subsequent CHIKV challenge and do not develop 
CHIKV-induced footpad swelling or disease. On the other hand, in immunocompetent C57/BL6 mice, CHIKV-NoLS CAF01-immunized mice developed delayed viremia at a similar titer compared to CHIKV-WT, and were protected from footpad swelling. However, immunization with either CHIKV-NoLS CAF01 or CHIKV-NoLS RNA produced significantly lower levels of neutralizing antibody compared to CHIKV-WT inoculation [126]. However, this study showed that the RNA-launched self-assembling viral particles generated immunity and protection that were just as strong as those of wild-type viral particles, suggesting the significant potential of this approach.

While multiple novel approaches have been explored to develop vaccines against alphaviruses, a potential prophylactic strategy that could be the development of a multivalent alphavirus vaccine given the reports of cross-neutralizing antibodies against conserved epitopes in the E2 protein across closely related alphaviruses. This approach would prove useful in endemic areas where alphavirus co-circulation occurs.

Supplementary Materials: The following are available online at https:/ /www.mdpi.com/article/10 $.3390 /$ microorganisms 9050899 /s1. Supplementary Figure S1. Alignment of E1 and E2 amino acid sequences of arthritogenic and encephalitic alphaviruses.

Author Contributions: Data curation and writing, A.T.-R. and R.S.-L.C.; conceptualization and supervision, L.F.P.N. All authors have read and agreed to the published version of the manuscript.

Funding: This research received no external funding.

Data Availability Statement: No new data were created or analyzed in this study. Data sharing is not applicable to this article.

Conflicts of Interest: The authors declare no conflict of interest.

\section{References}

1. Atkins, G.J. The Pathogenesis of Alphaviruses. ISRN Virol. 2013, 2013, 22. [CrossRef]

2. Zaid, A.; Burt, F.J.; Liu, X.; Poo, Y.S.; Zandi, K.; Suhrbier, A.; Weaver, S.; Texeira, M.; Mahalingam, S. Arthritogenic alphaviruses: Epidemiological and clinical perspective on emerging arboviruses. Lancet Infect. Dis. 2020. [CrossRef]

3. Suhrbier, A.; Jaffar-Bandjee, M.C.; Gasque, P. Arthritogenic alphaviruses-An overview. Nat. Rev. Rheumatol. 2012, 8, 420-429. [CrossRef] [PubMed]

4. Zacks, M.A.; Paessler, S. Encephalitic alphaviruses. Vet. Microbiol. 2010, 140, 281-286. [CrossRef] [PubMed]

5. Wahid, B.; Ali, A.; Rafique, S.; Idrees, M. Global expansion of chikungunya virus: Mapping the 64-year history. Int. J. Infect. Dis. 2017, 58, 69-76. [CrossRef]

6. Haddow, A.; Davies, C.W.; Walker, A.J. O'nyong-nyong fever: An epidemic virus disease in East Africa 1. Introduction. Trans. R. Soc. Trop. Med. Hyg. 1960, 54, 517-522. [CrossRef]

7. Bessaud, M.; Peyrefitte, C.N.; Pastorino, B.A.; Tock, F.; Merle, O.; Colpart, J.J.; Dehecq, J.S.; Girod, R.; Jaffar-Bandjee, M.C.; Glass, P. J.; et al. Chikungunya virus strains, Reunion Island outbreak. Emerg. Infect. Dis. 2006, 12, 1604-1606. [CrossRef]

8. Aaskov, J.G.; Mataika, J.U.; Lawrence, G.W.; Rabukawaqa, V.; Tucker, M.M.; Miles, J.A.; Dalglish, D.A. An epidemic of Ross River virus infection in Fiji, 1979. Am. J. Trop. Med. Hyg. 1981, 30, 1053-1059. [CrossRef]

9. Tsetsarkin, K.A.; Vanlandingham, D.L.; McGee, C.E.; Higgs, S. A single mutation in chikungunya virus affects vector specificity and epidemic potential. PLoS Pathog. 2007, 3, e201. [CrossRef]

10. Tsetsarkin, K.A.; McGee, C.E.; Volk, S.M.; Vanlandingham, D.L.; Weaver, S.C.; Higgs, S. Epistatic roles of E2 glycoprotein mutations in adaption of chikungunya virus to Aedes albopictus and Ae. aegypti mosquitoes. PLoS ONE 2009, 4, e6835. [CrossRef]

11. Rezza, G.; Chen, R.; Weaver, S.C. O'nyong-nyong fever: A neglected mosquito-borne viral disease. Pathog. Glob. Health 2017, 111, 271-275. [CrossRef]

12. Acosta-Ampudia, Y.; Monsalve, D.M.; Rodriguez, Y.; Pacheco, Y.; Anaya, J.M.; Ramirez-Santana, C. Mayaro: An emerging viral threat? Emerg. Microbe. Infect. 2018, 7, 163. [CrossRef]

13. Ganjian, N.; Riviere-Cinnamond, A. Mayaro virus in Latin America and the Caribbean. Rev. Panam. Salud. Publica 2020, 44, 14. [CrossRef]

14. Pezzi, L.; LaBeaud, A.D.; Reusken, C.B.; Drexler, J.F.; Vasilakis, N.; Diallo, M.; Simon, F.; Jaenisch, T.; Gallian, P.; Sall, A.; et al. GloPID-R report on chikungunya, o'nyong-nyong and Mayaro virus, part 2: Epidemiological distribution of o'nyong-nyong virus. Antivir. Res. 2019, 172, 104611. [CrossRef]

15. Pezzi, L.; Rodriguez-Morales, A.J.; Reusken, C.B.; Ribeiro, G.S.; LaBeaud, A.D.; Lourenço-de-Oliveira, R.; Brasil, P.; Lecuit, M.; Failloux, A.B.; Gallian, P.; et al. GloPID-R report on chikungunya, o'nyong-nyong and Mayaro virus, part 3: Epidemiological distribution of Mayaro virus. Antivir. Res. 2019, 172, 104610. [CrossRef] 
16. Pezzi, L.; Reusken, C.B.; Weaver, S.C.; Drexler, J.F.; Busch, M.; LaBeaud, A.D.; Diamond, M. S.; Vasilakis, N.; Drebot, M. A.; Siqueira, A.M.; et al. GloPID-R report on Chikungunya, O'nyong-nyong and Mayaro virus, part I: Biological diagnostics. Antivir. Res. 2019, 166, 66-81. [CrossRef]

17. Seyler, T.; Hutin, Y.; Ramanchandran, V.; Ramakrishnan, R.; Manickam, P.; Murhekar, M. Estimating the burden of disease and the economic cost attributable to chikungunya, Andhra Pradesh, India, 2005-2006. Trans. R. Soc. Trop. Med. Hyg. 2010, 104, 133-138. [CrossRef]

18. Alvis-Zakzuk, N.J.; Diaz-Jimenez, D.; Castillo-Rodriguez, L.; Castaneda-Orjuela, C.; Paternina-Caicedo, A.; Pinzon-Redondo, H.; Carrasquilla-Sotomayor, M.; Alvis-Guzmán, N.; De La Hoz-Restrepo, F. Economic Costs of Chikungunya Virus in Colombia. Value Health Reg. Issues 2018, 17, 32-37. [CrossRef]

19. Thompson, R.; del Martin Campo, J.; Constenla, D. A review of the economic evidence of Aedes-borne arboviruses and Aedes-borne arboviral disease prevention and control strategies. Expert Rev. Vaccin. 2020, 19, 143-162. [CrossRef]

20. Cunha, R.V.D.; Trinta, K.S. Chikungunya virus: Clinical aspects and treatment-A Review. Mem. Inst. Oswaldo Cruz 2017, 112, 523-531. [CrossRef] [PubMed]

21. Lundstrom, K. Alphavirus-based vaccines. Viruses 2014, 6, 2392-2415. [CrossRef]

22. Panning, M.; Grywna, K.; van Esbroeck, M.; Emmerich, P.; Drosten, C. Chikungunya fever in travelers returning to Europe from the Indian Ocean region, 2006. Emerg. Infect. Dis. 2008, 14, 416-422. [CrossRef] [PubMed]

23. Kam, Y.W.; Lum, F.M.; Teo, T.H.; Lee, W.W.; Simarmata, D.; Harjanto, S.; Chua, C.L.; Chan, Y.F.; Wee, J.K.; Chow, A.; et al. Early neutralizing IgG response to Chikungunya virus in infected patients targets a dominant linear epitope on the E2 glycoprotein. EMBO Mol. Med. 2012, 4, 330-343. [CrossRef] [PubMed]

24. Pierro, A.; Rossini, G.; Gaibani, P.; Finarelli, A.C.; Moro, M.L.; Landini, M.P.; Sambri, V. Persistence of anti-chikungunya virusspecific antibodies in a cohort of patients followed from the acute phase of infection after the 2007 outbreak in Italy. New Microbe. New Infect. 2015, 7, 23-25. [CrossRef]

25. Chua, C.L.; Sam, I.C.; Chiam, C.W.; Chan, Y.F. The neutralizing role of IgM during early Chikungunya virus infection. PLoS ONE 2017, 12, e0171989.

26. Borgherini, G.; Poubeau, P.; Staikowsky, F.; Lory, M.; Le Moullec, N.; Becquart, J.P.; Wengling, C.; Michault, A.; Paganin, F. Outbreak of chikungunya on Reunion Island: Early clinical and laboratory features in 157 adult patients. Clin. Infect. Dis. 2007, 44, 1401-1407. [CrossRef]

27. Malvy, D.; Ezzedine, K.; Mamani-Matsuda, M.; Autran, B.; Tolou, H.; Receveur, M-C.; Pistone, T.; Rambert, J.; Moynet, D.; Mossalayi, D. Destructive arthritis in a patient with chikungunya virus infection with persistent specific IgM antibodies. BMC Infect. Dis. 2009, 9, 200. [CrossRef]

28. Bozza, F.A.; Moreira-Soto, A.; Rockstroh, A.; Fischer, C.; Nascimento, A.D.; Calheiros, A.S.; Drosten, C.; Bozza, P.T.; Souza, T.; Ulbert, S.; et al. Differential Shedding and Antibody Kinetics of Zika and Chikungunya Viruses, Brazil. Emerg. Infect. Dis. 2019, 25, 311-315. [CrossRef]

29. Nitatpattana, N.; Kanjanopas, K.; Yoksan, S.; Satimai, W.; Vongba, N.; Langdatsuwan, S.; Nakgoi, K.; Ratchakum, S.; Wauquier, N.; Souris, M.; et al. Long-term persistence of Chikungunya virus neutralizing antibodies in human populations of North Eastern Thailand. Virol. J. 2014, 11, 183. [CrossRef]

30. Shore, H. O'nyong-nyong fever: An epidemic virus disease in East Africa: III Some clinical and epidemiological observations in the Northern Province of Uganda. Trans. R. Soc. Trop. Med. Hyg. 1961, 55, 361-373. [CrossRef]

31. Williams, M.C.; Woodall, J.P.; Corbet, P.S.; Gillett, J.D. O'nyong-Nyong Fever: An Epidemic Virus Disease in East Africa. 8. Virus Isolations from Anopheles Mosquitoes. Trans. R. Soc. Trop. Med. Hyg. 1965, 59, 300-306. [CrossRef]

32. Kiwanuka, N.; Sanders, E.J.; Rwaguma, E.B.; Kawamata, J.; Ssengooba, F.P.; Najjemba, R.; Were, W.A.; Lamunu, M.; Bagambisa, G.; Burkot, T.R.; et al. O'nyong-nyong fever in south-central Uganda, 1996-1997: Clinical features and validation of a clinical case definition for surveillance purposes. Clin. Infect. Dis. 1999, 29, 1243-1250. [CrossRef]

33. Tappe, D.; Kapaun, A.; Emmerich, P.; de Mendonca Campos, R.; Cadar, D.; Gunther, S.; Schmidt-Chanasit, J. O'nyong-nyong virus infection imported to Europe from Kenya by a traveler. Emerg. Infect. Dis. 2014, 20, 1766-1767. [CrossRef]

34. Bessaud, M.; Peyrefitte, C.N.; Pastorino, B.A.; Gravier, P.; Tock, F.; Boete, F.; Tolou, H.J.; Grandadam, M. O'nyong-nyong Virus, Chad. Emerg. Infect. Dis. 2006, 12, 1248-1250. [CrossRef]

35. Diagne, C.T.; Bengue, M.; Choumet, V.; Hamel, R.; Pompon, J.; Misse, D. Mayaro Virus Pathogenesis and Transmission Mechanisms. Pathogens 2020, 9, 738. [CrossRef]

36. Mourao, M.P.; Bastos, M.D.S.; de Figueiredo, R.P.; Gimaque, J.B.; Galusso Edos, S.; Kramer, V.M.; de Oliveira, C.M.; Naveca, F.G.; Figueiredo, L.T. Mayaro fever in the city of Manaus, Brazil, 2007-2008. Vector Borne Zoonotic Dis. 2012, 12, 42-46. [CrossRef]

37. Halsey, E.S.; Siles, C.; Guevara, C.; Vilcarromero, S.; Jhonston, E.J.; Ramal, C.; Aguilar, P.V.; Ampuero, J.S. Mayaro virus infection, Amazon Basin region, Peru, 2010-2013. Emerg. Infect. Dis. 2013, 19, 1839-1842. [CrossRef]

38. Figueiredo, L.T.; Nogueira, R.M.; Cavalcanti, S.M.; Schatzmayr, H.; da Rosa, A.T. Study of two different enzyme immunoassays for the detection of Mayaro virus antibodies. Mem. Inst. Oswaldo Cruz 1989, 84, 303-307. [CrossRef]

39. Santiago, F.W.; Halsey, E.S.; Siles, C.; Vilcarromero, S.; Guevara, C.; Silvas, J.A.; Ramal, C.; Ampuero, J.S.; Aguilar, P.V. Long-Term Arthralgia after Mayaro Virus Infection Correlates with Sustained Pro-inflammatory Cytokine Response. PLoS Negl. Trop. Dis. 2015, 9, e0004104. [CrossRef] 
40. Harley, D.; Sleigh, A.; Ritchie, S. Ross River virus transmission, infection, and disease: A cross-disciplinary review. Clin. Microbiol. Rev. 2001, 14, 909-932. [CrossRef]

41. Farmer, J.F.; Suhrbier, A. Interpreting paired serology for Ross River virus and Barmah Forest virus diseases. Aust. J. Gen. Pract. 2019, 48, 645-649. [CrossRef] [PubMed]

42. Barton, A.J.; Bielefeldt-Ohmann, H. Clinical Presentation, Progression, and Management of Five Cases of Ross River Virus Infection in Performance Horses Located in Southeast Queensland: A Longitudinal Case Series. J. Equin. Vet. Sci. 2017, 51, 34-40. [CrossRef]

43. Azuolas, J.K.; Wishart, E.; Bibby, S.; Ainsworth, C. Isolation of Ross River virus from mosquitoes and from horses with signs of musculo-skeletal disease. Aust. Vet. J. 2003, 81, 344-347. [CrossRef] [PubMed]

44. Kapeleris, J.; Lowe, P.; Phillips, D.; Wyatt, D.; Batham, M.; Devine, P. IgG avidity in the diagnosis of acute Ross River virus infection. Dis. Marker. 1996, 12, 279-282. [CrossRef]

45. Calisher, C.H.; Meurman, O.; Brummer-Korvenkontio, M.; Halonen, P.E.; Muth, D.J. Sensitive enzyme immunoassay for detecting immunoglobulin $\mathrm{M}$ antibodies to Sindbis virus and further evidence that Pogosta disease is caused by a western equine encephalitis complex virus. J. Clin. Microbiol. 1985, 22, 566-571. [CrossRef]

46. Kurkela, S.; Manni, T.; Myllynen, J.; Vaheri, A.; Vapalahti, O. Clinical and laboratory manifestations of Sindbis virus infection: Prospective study, Finland, 2002-2003. J. Infect. Dis. 2005, 191, 1820-1829. [CrossRef]

47. Niklasson, B.; Espmark, A.; Lundstrom, J. Occurrence of arthralgia and specific IgM antibodies three to four years after Ockelbo disease. J. Infect. Dis. 1988, 157, 832-835. [CrossRef]

48. Griffin, D.E. Neurotropic Alphaviruses. In Neurotropic Viral Infections, 2nd ed.; Reis, C.S., Ed.; Springer International Publishing: Cham, Switzerland, 2016; pp. 175-204.

49. Calisher, C.H.; Berardi, V.P.; Muth, D.J.; Buff, E.E. Specificity of immunoglobulin M and G antibody responses in humans infected with eastern and western equine encephalitis viruses: Application to rapid serodiagnosis. J. Clin. Microbiol. 1986, 23, 369-372. [CrossRef]

50. Gardner, J.; Anraku, I.; Le, T.T.; Larcher, T.; Major, L.; Roques, P.; Schroder, W.A.; Higgs, S.; Suhrbier, A. Chikungunya virus arthritis in adult wild-type mice. J. Virol. 2010, 84, 8021-8032. [CrossRef]

51. Poo, Y.S.; Rudd, P.A.; Gardner, J.; Wilson, J.A.; Larcher, T.; Colle, M.A.; Le, T.T.; Nakaya, H.I.; Warrilow, D.; Allcock, R.; et al. Multiple immune factors are involved in controlling acute and chronic chikungunya virus infection. PLoS Negl. Trop. Dis. 2014, 8, e3354. [CrossRef]

52. Hawman, D.W.; Stoermer, K.A.; Montgomery, S.A.; Pal, P.; Oko, L.; Diamond, M.S.; Morrison, T.E. Chronic joint disease caused by persistent Chikungunya virus infection is controlled by the adaptive immune response. J. Virol. 2013, 87, 13878-13888. [CrossRef]

53. Johnson, R.T. Virus Invasion of the Central Nervous System: A Study of Sindbis Virus Infection in the Mouse Using Fluorescent Antibody. Am. J. Pathol. 1965, 46, 929-943.

54. Burdeinick-Kerr, R.; Wind, J.; Griffin, D.E. Synergistic roles of antibody and interferon in noncytolytic clearance of Sindbis virus from different regions of the central nervous system. J. Virol. 2007, 81, 5628-5636. [CrossRef]

55. Nilaratanakul, V.; Chen, J.; Tran, O.; Baxter, V.K.; Troisi, E.M.; Yeh, J.X.; Griffin, D.E. Germ Line IgM Is Sufficient, but Not Required, for Antibody-Mediated Alphavirus Clearance from the Central Nervous System. J. Virol. 2018, 92, e02081-17. [CrossRef]

56. Fragkoudis, R.; Ballany, C.M.; Boyd, A.; Fazakerley, J.K. In Semliki Forest virus encephalitis, antibody rapidly clears infectious virus and is required to eliminate viral material from the brain, but is not required to generate lesions of demyelination. J. Gen. Virol. 2008, 89, 2565-2568. [CrossRef]

57. Amor, S.; Scallan, M.F.; Morris, M.M.; Dyson, H.; Fazakerley, J.K. Role of immune responses in protection and pathogenesis during Semliki Forest virus encephalitis. J. Gen. Virol. 1996, 77, 281-291. [CrossRef]

58. Fazakerley, J.K.; Webb, H.E. Semliki Forest virus-induced, immune-mediated demyelination: Adoptive transfer studies and viral persistence in nude mice. J. Gen. Virol. 1987, 68, 377-385. [CrossRef]

59. Metcalf, T.U.; Baxter, V.K.; Nilaratanakul, V.; Griffin, D.E. Recruitment and retention of B cells in the central nervous system in response to alphavirus encephalomyelitis. J. Virol. 2013, 87, 2420-2429. [CrossRef]

60. Metcalf, T.U.; Griffin, D.E. Alphavirus-induced encephalomyelitis: Antibody-secreting cells and viral clearance from the nervous system. J. Virol. 2011, 85, 11490-11501. [CrossRef]

61. Teo, T.H.; Lum, F.M.; Claser, C.; Lulla, V.; Lulla, A.; Merits, A.; Renia, L.; Ng, L. F. A pathogenic role for CD4+ T cells during Chikungunya virus infection in mice. J. Immunol. 2013, 190, 259-269. [CrossRef]

62. Lum, F.M.; Teo, T.H.; Lee, W.W.; Kam, Y.W.; Renia, L.; Ng, L.F. An essential role of antibodies in the control of Chikungunya virus infection. J. Immunol. 2013, 190, 6295-6302. [CrossRef]

63. Olitsky, P.K.; Cox, H.R. Active Immunication of Guinea Pigs with the Virus of Equine Encephalomyelitis: I. Quantitative Experiments with Various Preparations of Active Virus. J. Exp. Med. 1936, 63, 311-324. [CrossRef]

64. Cox, H.R.; Olitsky, P.K. Active Immunization of Guinea Pigs with the Virus of Equine Encephalomyelitis: Iii. Quantitative Studies of Serum Antiviral Bodies in Animals Immunized with Active and Inactive Virus. J. Exp. Med. 1936, 64, 217-222. [CrossRef]

65. Cox, H.R.; Olitsky, P.K. Active Immunization of Guinea Pigs with the Virus of Equine Encephalomyelitis: Iv. Effect of Immune Serum on Antigenicity of Active and Inactive Virus. J. Exp. Med. 1936, 64, 223-232. [CrossRef] [PubMed] 
66. Olitsky, P.K.; Harford, C.G. Intraperitoneal and Intracerebral Routes in Serum Protection Tests with the Virus of Equine Encephalomyelitis: Iii. Comparison of Antiviral Serum Constituents from Guinea Pigs Immunized with Active or Formolized Inactive Virus. J. Exp. Med. 1938, 68, 779-787. [CrossRef]

67. Morgan, I.M.; Schlesinger, R.W.; Olitsky, P.K. Induced Resistance of the Central Nervous System to Experimental Infection with Equine Encephalomyelitis Virus: I. Neutralizing Antibody in the Central Nervous System in Relation to Cerebral Resistance. J. Exp. Med. 1942, 76, 357-369. [CrossRef]

68. Griffin, D.E.; Johnson, R.T. Role of the immune response in recovery from Sindbis virus encephalitis in mice. J. Immunol. 1977, $118,1070-1075$.

69. Kimura, T.; Griffin, D.E. Extensive immune-mediated hippocampal damage in mice surviving infection with neuroadapted Sindbis virus. Virology 2003, 311, 28-39. [CrossRef]

70. Rabinowitz, S.G.; Adler, W.H. Host defenses during primary Venezuelan equine encephalomyelitis virus infection in mice. I. Passive transfer of protection with immune serum and immune cells. J. Immunol. 1973, 110, 1345-1353. [PubMed]

71. Couderc, T.; Khandoudi, N.; Grandadam, M.; Visse, C.; Gangneux, N.; Bagot, S.; Prost, J. F.; Lecuit, M. Prophylaxis and therapy for Chikungunya virus infection. J. Infect. Dis. 2009, 200, 516-523. [CrossRef] [PubMed]

72. Lee, C.Y.; Kam, Y.W.; Fric, J.; Malleret, B.; Koh, E.G.; Prakash, C.; Huang, W.; Lee, W. W.; Lin, C.; Lin, R. T. Chikungunya virus neutralization antigens and direct cell-to-cell transmission are revealed by human antibody-escape mutants. PLoS Pathog. 2011, 7 , e1002390. [CrossRef]

73. Holzer, G.W.; Coulibaly, S.; Aichinger, G.; Savidis-Dacho, H.; Mayrhofer, J.; Brunner, S.; Schmid, K.; Kistner, O.; Aaskov, J. G.; Falkner, F.G.; et al. Evaluation of an inactivated Ross River virus vaccine in active and passive mouse immunization models and establishment of a correlate of protection. Vaccine 2011, 29, 4132-4141. [CrossRef]

74. Kraaijeveld, C.A.; Benaissa-Trouw, B.J.; Harmsen, M.; Snippe, H. Adoptive transfer of immunity against virulent Semliki Forest virus with immune spleen cells from mice infected with avirulent Semliki Forest virus. Arch. Virol. 1986, 91, 83-92. [CrossRef]

75. Jose, J.; Snyder, J.E.; Kuhn, R.J. A structural and functional perspective of alphavirus replication and assembly. Future Microbiol. 2009, 4, 837-856. [CrossRef]

76. Stec, D.S.; Waddell, A.; Schmaljohn, C.S.; Cole, G.A.; Schmaljohn, A.L. Antibody-selected variation and reversion in Sindbis virus neutralization epitopes. J. Virol. 1986, 57,715-720. [CrossRef]

77. Boere, W.A.; Harmsen, T.; Vinje, J.; Benaissa-Trouw, B.J.; Kraaijeveld, C.A.; Snippe, H. Identification of distinct antigenic determinants on Semliki Forest virus by using monoclonal antibodies with different antiviral activities. J. Virol. 1984, 52, 575-582. [CrossRef]

78. Roehrig, J.T.; Mathews, J.H. The neutralization site on the E2 glycoprotein of Venezuelan equine encephalomyelitis (TC-83) virus is composed of multiple conformationally stable epitopes. Virology 1985, 142, 347-356. [CrossRef]

79. Vrati, S.; Fernon, C.A.; Dalgarno, L.; Weir, R.C. Location of a major antigenic site involved in Ross River virus neutralization. Virology 1988, 162, 346-353. [CrossRef]

80. Navaratnarajah, C.K.; Kuhn, R.J. Functional characterization of the Sindbis virus E2 glycoprotein by transposon linker-insertion mutagenesis. Virology 2007, 363, 134-147. [CrossRef]

81. Hunt, A.R.; Frederickson, S.; Maruyama, T.; Roehrig, J.T.; Blair, C.D. The first human epitope map of the alphaviral E1 and E2 proteins reveals a new E2 epitope with significant virus neutralizing activity. PLoS Negl. Trop. Dis. 2010, 4, e739. [CrossRef]

82. Kam, Y.W.; Lee, W.W.; Simarmata, D.; Le Grand, R.; Tolou, H.; Merits, A.; Roques, P.; Ng, L. F. Unique epitopes recognized by antibodies induced in Chikungunya virus-infected non-human primates: Implications for the study of immunopathology and vaccine development. PLoS ONE 2014, 9, e95647. [CrossRef] [PubMed]

83. Adouchief, S.; Smura, T.; Vapalahti, O.; Hepojoki, J. Mapping of human B-cell epitopes of Sindbis virus. J. Gen. Virol. 2016, 97, 2243-2254. [CrossRef] [PubMed]

84. Chanas, A.C.; Gould, E.A.; Clegg, J.C.; Varma, M.G. Monoclonal antibodies to Sindbis virus glycoprotein E1 can neutralize, enhance infectivity, and independently inhibit haemagglutination or haemolysis. J. Gen. Virol. 1982, 58, 37-46. [CrossRef] [PubMed]

85. Despres, P.; Griffin, J.W.; Griffin, D.E. Antiviral activity of alpha interferon in Sindbis virus-infected cells is restored by anti-E2 monoclonal antibody treatment. J. Virol. 1995, 69, 7345-7348. [CrossRef]

86. Despres, P.; Griffin, J.W.; Griffin, D.E. Effects of anti-E2 monoclonal antibody on sindbis virus replication in AT3 cells expressing bcl-2. J. Virol. 1995, 69, 7006-7014. [CrossRef]

87. Mendoza, Q.P.; Stanley, J.; Griffin, D.E. Monoclonal antibodies to the E1 and E2 glycoproteins of Sindbis virus: Definition of epitopes and efficiency of protection from fatal encephalitis. J. Gen. Virol. 1988, 69, 3015-3022. [CrossRef]

88. Stanley, J.; Cooper, S.J.; Griffin, D.E. Monoclonal antibody cure and prophylaxis of lethal Sindbis virus encephalitis in mice. J. Virol. 1986, 58, 107-115. [CrossRef]

89. Boere, W.A.; Benaissa-Trouw, B.J.; Harmsen, T.; Erich, T.; Kraaijeveld, C.A.; Snippe, H. Mechanisms of monoclonal antibodymediated protection against virulent Semliki Forest virus. J. Virol. 1985, 54, 546-551. [CrossRef]

90. Smith, S.A.; Silva, L.A.; Fox, J.M.; Flyak, A.I.; Kose, N.; Sapparapu, G.; Khomandiak, S.; Ashbrook, A. W.; Kahle, K. M.; Fong, R. H; et al. Isolation and Characterization of Broad and Ultrapotent Human Monoclonal Antibodies with Therapeutic Activity against Chikungunya Virus. Cell Host Microbe 2015, 18, 86-95. [CrossRef]

91. Chua, C.L.; Chan, Y.F.; Sam, I.C. Characterisation of mouse monoclonal antibodies targeting linear epitopes on Chikungunya virus E2 glycoprotein. J. Virol. Method. 2014, 195, 126-133. [CrossRef] 
92. Pal, P.; Dowd, K.A.; Brien, J.D.; Edeling, M.A.; Gorlatov, S.; Johnson, S.; Lee, I.; Akahata, W.; Nabel, G. J.; Richter, M. K.; et al. Development of a highly protective combination monoclonal antibody therapy against Chikungunya virus. PLoS Pathog. 2013, 9, e1003312. [CrossRef]

93. Goh, L.Y.; Hobson-Peters, J.; Prow, N.A.; Baker, K.; Piyasena, T.B.; Taylor, C.T.; Rana, A.; Hastie, M. L.; Gorman, J. J.; Hall, R. A. The Chikungunya Virus Capsid Protein Contains Linear B Cell Epitopes in the N- and C-Terminal Regions that are Dependent on an Intact C-Terminus for Antibody Recognition. Viruses 2015, 7, 2943-2964. [CrossRef]

94. Goh, L.Y.H.; Hobson-Peters, J.; Prow, N.A.; Gardner, J.; Bielefeldt-Ohmann, H.; Suhrbier, A.; Hall, R. A. Monoclonal antibodies specific for the capsid protein of chikungunya virus suitable for multiple applications. J. Gen. Virol. 2015, 96, 507-512. [CrossRef]

95. Sun, S.; Xiang, Y.; Akahata, W.; Holdaway, H.; Pal, P.; Zhang, X.; Diamond, M. S.; Nabel, G. J.; Rossmann, M. G. Structural analyses at pseudo atomic resolution of Chikungunya virus and antibodies show mechanisms of neutralization. eLife 2013, 2, e00435. [CrossRef]

96. Voss, J.E.; Vaney, M.C.; Duquerroy, S.; Vonrhein, C.; Girard-Blanc, C.; Crublet, E.; Thompson, A.; Bricogne, G.; Rey, F. A. Glycoprotein organization of Chikungunya virus particles revealed by X-ray crystallography. Nature 2010, 468, 709-712. [CrossRef]

97. Broeckel, R.; Fox, J.M.; Haese, N.; Kreklywich, C.N.; Sukulpovi-Petty, S.; Legasse, A.; Smith, P. P.; Denton, M.; Corvey, C.; Krishnan, S.; et al. Therapeutic administration of a recombinant human monoclonal antibody reduces the severity of chikungunya virus disease in rhesus macaques. PLoS Negl. Trop. Dis. 2017, 11, e0005637. [CrossRef]

98. Fox, J.M.; Long, F.; Edeling, M.A.; Lin, H.; van Duijl-Richter, M.K.S.; Fong, R.H.; Kahle, K. M.; Smit, J. M.; Jin, J.; Simmons, G.; et al. Broadly Neutralizing Alphavirus Antibodies Bind an Epitope on E2 and Inhibit Entry and Egress. Cell 2015, 163, 1095-1107. [CrossRef]

99. Kim, A.S.; Austin, S.K.; Gardner, C.L.; Zuiani, A.; Reed, D.S.; Trobaugh, D.W.; Sun, C.; Basore, K.; Williamson, L. E.; Crowe, J. E; et al. Protective antibodies against Eastern equine encephalitis virus bind to epitopes in domains A and B of the E2 glycoprotein. Nat. Microbiol. 2019, 4, 187-197. [CrossRef]

100. Zhao, J.; Sun, E.C.; Liu, N.H.; Yang, T.; Xu, Q.Y.; Qin, Y.L.; Yang, Y. H.; Wu, D. L. Phage display identifies an Eastern equine encephalitis virus glycoprotein E2-specific B cell epitope. Vet. Immunol. Immunopathol. 2012, 148, 364-368. [CrossRef]

101. Sun, E.C.; Zhao, J.; Yang, T.; Xu, Q.Y.; Qin, Y.L.; Wang, W.S.; Wei, P.; Sun, L.; Sun, J.; Wu, D.L. Analysis of murine B-cell epitopes on Eastern equine encephalitis virus glycoprotein E2. Appl. Microbiol. Biotechnol. 2013, 97, 6359-6372.

102. Powell, L.A.; Fox, J.M.; Kose, N.; Kim, A.S.; Majedi, M.; Bombardi, R.; Carnahan, R. H.; Slaughter, J. C.; Morrison, T. E.; Diamond, M.; et al. Human monoclonal antibodies against Ross River virus target epitopes within the E2 protein and protect against disease. PLoS Pathog. 2020, 16, e1008517. [CrossRef] [PubMed]

103. Earnest, J.T.; Basore, K.; Roy, V.; Bailey, A.L.; Wang, D.; Alter, G.; Fremont, D. H.; Diamond, M. S. Neutralizing antibodies against Mayaro virus require Fc effector functions for protective activity. J. Exp. Med. 2019, 216, 2282-2301. [CrossRef] [PubMed]

104. Zhang, R.; Kim, A.S.; Fox, J.M.; Nair, S.; Basore, K.; Klimstra, W.B.; Rimkunas, R.; Fong, R. H.; Lin, H.; Poddar, S.; et al. Mxra8 is a receptor for multiple arthritogenic alphaviruses. Nature 2018, 557, 570-574. [CrossRef]

105. Zhang, R.; Earnest, J.T.; Kim, A.S.; Winkler, E.S.; Desai, P.; Adams, L.J.; Hu, G.; Bullock, C.; Gold, B.; Cherry, S.; et al. Expression of the Mxra8 Receptor Promotes Alphavirus Infection and Pathogenesis in Mice and Drosophila. Cell Rep. 2019, 28, 2647-2658.e5. [CrossRef] [PubMed]

106. Basore, K.; Kim, A.S.; Nelson, C.A.; Zhang, R.; Smith, B.K.; Uranga, C.; Vang, L.; Cheng, M.; Gross, M. L.; Smith, J.; et al. Cryo-EM Structure of Chikungunya Virus in Complex with the Mxra8 Receptor. Cell 2019, 177, 1725-1737.e16. [CrossRef] [PubMed]

107. Song, H.; Zhao, Z.; Chai, Y.; Jin, X.; Li, C.; Yuan, F.; Liu, S.; Gao, Z.; Wang, H.; Song, J.; et al. Molecular Basis of Arthritogenic Alphavirus Receptor MXRA8 Binding to Chikungunya Virus Envelope Protein. Cell 2019, 177, 1714-1724.e12. [CrossRef] [PubMed]

108. Gould, E.; Pettersson, J.; Higgs, S.; Charrel, R.; de Lamballerie, X. Emerging arboviruses: Why today? One Health 2017, 4, 1-13. [CrossRef]

109. Weaver, S.C. Urbanization and geographic expansion of zoonotic arboviral diseases: Mechanisms and potential strategies for prevention. Trends Microbiol. 2013, 21, 360-363. [CrossRef]

110. Zahouli, J.B.Z.; Koudou, B.G.; Muller, P.; Malone, D.; Tano, Y.; Utzinger, J. Urbanization is a main driver for the larval ecology of Aedes mosquitoes in arbovirus-endemic settings in south-eastern Cote d'Ivoire. PLoS Negl. Trop. Dis. 2017, 11, e0005751. [CrossRef]

111. Kilpatrick, A.M.; Randolph, S.E. Drivers, dynamics, and control of emerging vector-borne zoonotic diseases. Lancet 2012, 380, 1946-1955. [CrossRef]

112. Vazeille, M.; Moutailler, S.; Pages, F.; Jarjaval, F.; Failloux, A.B. Introduction of Aedes albopictus in Gabon: What consequences for dengue and chikungunya transmission? Trop. Med. Int. Health 2008, 13, 1176-1179. [CrossRef]

113. Naish, S.; Hu, W.; Mengersen, K.; Tong, S. Spatio-temporal patterns of Barmah Forest virus disease in Queensland, Australia. PLoS ONE 2011, 6, e25688. [CrossRef]

114. Reed, D.S.; Glass, P.J.; Bakken, R.R.; Barth, J.F.; Lind, C.M.; da Silva, L.; Hart, M.K.; Rayner, J.; Alterson, K.; Custer, M.; et al. Combined alphavirus replicon particle vaccine induces durable and cross-protective immune responses against equine encephalitis viruses. J. Virol. 2014, 88, 12077-12086. [CrossRef]

115. Wressnigg, N.; van der Velden, M.V.; Portsmouth, D.; Draxler, W.; O’Rourke, M.; Richmond, P.; Hall, S.; McBride, W.J.H.; Redfern, A.; Aaskvo, J.; et al. An inactivated Ross River virus vaccine is well tolerated and immunogenic in an adult population in a randomized phase 3 trial. Clin. Vaccine Immunol. 2015, 22, 267-273. [CrossRef] 
116. Chang, L.J.; Dowd, K.A.; Mendoza, F.H.; Saunders, J.G.; Sitar, S.; Plummer, S.H.; Yamshchikov, G.; Sarwar, U.N.; Hu, Z.; Enama, M.E.; et al. Safety and tolerability of chikungunya virus-like particle vaccine in healthy adults: A phase 1 dose-escalation trial. Lancet 2014, 384, 2046-2052. [CrossRef]

117. Chen, G.L.; Coates, E.E.; Plummer, S.H.; Carter, C.A.; Berkowitz, N.; Conan-Cibotti, M.; Cox, J.H.; Beck, A.; O'Callahan, M.; Andrews, C.; et al. Effect of a Chikungunya Virus-Like Particle Vaccine on Safety and Tolerability Outcomes: A Randomized Clinical Trial. JAMA 2020, 323, 1369-1377. [CrossRef]

118. Akahata, W.; Nabel, G.J. A specific domain of the Chikungunya virus E2 protein regulates particle formation in human cells: Implications for alphavirus vaccine design. J. Virol. 2012, 86, 8879-8883. [CrossRef]

119. Chen, R.; Puri, V.; Fedorova, N.; Lin, D.; Hari, K.L.; Jain, R.; Rodas, J.D.; Das, S.R.; Shabman, R.S.; Weaver, S.C. Comprehensive Genome Scale Phylogenetic Study Provides New Insights on the Global Expansion of Chikungunya Virus. J. Virol. 2016, 90, 10600-10611. [CrossRef]

120. Xavier, J.; Fonseca, V.; Bezerra, J.F.; do Monte Alves, M.; Mares-Guia, M.A.; Claro, I.M.; de Jesus, R.; Adelino, T.; Araújo, E.; Cavalcante, K.R.L.J; et al. Chikungunya virus ECSA lineage reintroduction in the northeasternmost region of Brazil. Int. J. Infect. Dis. 2021, 105, 120-123. [CrossRef]

121. Phadungsombat, J.; Imad, H.; Rahman, M.; Nakayama, E.E.; Kludkleeb, S.; Ponam, T.; Rahim, R.; Hasan, A.; Poltep, K.; Yamanaka, A.; et al. A Novel Sub-Lineage of Chikungunya Virus East/Central/South African Genotype Indian Ocean Lineage Caused Sequential Outbreaks in Bangladesh and Thailand. Viruses 2020, 12, 1319. [CrossRef]

122. Fabri, A.A.; Rodrigues, C.; Santos, C.C.D.; Chalhoub, F.L.L.; Sampaio, S.A.; Faria, N.; Torres, M.C.; Fonseca, V.; Brasil, P.; Calvet, G.; et al. Co-Circulation of Two Independent Clades and Persistence of CHIKV-ECSA Genotype during Epidemic Waves in Rio de Janeiro, Southeast Brazil. Pathogens 2020, 9, 984. [CrossRef] [PubMed]

123. Harsha, P.K.; Reddy, V.; Rao, D.; Pattabiraman, C.; Mani, R.S. Continual circulation of ECSA genotype and identification of a novel mutation I317V in the E1 gene of Chikungunya viral strains in southern India during 2015-2016. J. Med. Virol. 2020, 92, 1007-1012. [CrossRef] [PubMed]

124. Akahata, W.; Yang, Z.Y.; Andersen, H.; Sun, S.; Holdaway, H.A.; Kong, W.P; Lewis, M.G.; Higgs, S.; Rossmann, M.G.; Rao, S.; et al. A virus-like particle vaccine for epidemic Chikungunya virus protects nonhuman primates against infection. Nat. Med. 2010, 16, 334-338. [CrossRef] [PubMed]

125. Erasmus, J.H.; Seymour, R.L.; Kaelber, J.T.; Kim, D.Y.; Leal, G.; Sherman, M.B.; Frolov, I.; Chiu, W.; Weaver, S.C.; Nasar, F. Novel Insect-Specific Eilat Virus-Based Chimeric Vaccine Candidates Provide Durable, Mono- and Multivalent, Single-Dose Protection against Lethal Alphavirus Challenge. J. Virol. 2018, 92, e01274-17.

126. Abeyratne, E.; Tharmarajah, K.; Freitas, J.R.; Mostafavi, H.; Mahalingam, S.; Zaid, A.; Zaman, M.; Taylor, A. Liposomal Delivery of the RNA Genome of a Live-Attenuated Chikungunya Virus Vaccine Candidate Provides Local, but Not Systemic Protection After One Dose. Front. Immunol. 2020, 11, 304. [CrossRef]

127. Taylor, A.; Liu, X.; Zaid, A.; Goh, L.Y.; Hobson-Peters, J.; Hall, R.A.; Merits, A.; Mahalingam, S. Mutation of the N-Terminal Region of Chikungunya Virus Capsid Protein: Implications for Vaccine Design. mBio 2017, 8, e01970-16. [CrossRef]

128. Kistner, O.; Barrett, N.; Bruhmann, A.; Reiter, M.; Mundt, W.; Savidis-Dacho, H.; Schober-Bendixen, S.; Dorner, F.; Aaskov, J. The preclinical testing of a formaldehyde inactivated Ross River virus vaccine designed for use in humans. Vaccine 2007, 25, 4845-4852. [CrossRef]

129. Aichinger, G.; Ehrlich, H.J.; Aaskov, J.G.; Fritsch, S.; Thomasser, C.; Draxler, W.; Wolzt, M.; Muller, M.; Pinl, F.; Van Damme, P.; et al. Safety and immunogenicity of an inactivated whole virus Vero cell-derived Ross River virus vaccine: A randomized trial. Vaccine 2011, 29, 9376-9384. [CrossRef]

130. Chan, Y.H.; Teo, T.H.; Utt, A.; Tan, J.J.; Amrun, S.N.; Abu Bakar, F.; Yee, W.-X.; Becht, E.; Lee, C.Y.-P.; Lee, B.; et al. Mutating chikungunya virus non-structural protein produces potent live-attenuated vaccine candidate. EMBO Mol. Med. 2019, 11, e10092. [CrossRef]

131. Hallengard, D.; Kakoulidou, M.; Lulla, A.; Kummerer, B.M.; Johansson, D.X.; Mutso, M.; Lulla, V.; Fazakerley, J.K.; Roques, P.; Le Grand, R.; et al. Novel attenuated Chikungunya vaccine candidates elicit protective immunity in C57BL/6 mice. J. Virol. 2014, 88, 2858-2866. [CrossRef]

132. Roques, P.; Ljungberg, K.; Kummerer, B.M.; Gosse, L.; Dereuddre-Bosquet, N.; Tchitchek, N.; Hallengard, D.; Garcia-Arriaza, J.; Meinke, A.; Esteban, M.; et al. Attenuated and vectored vaccines protect nonhuman primates against Chikungunya virus. JCI Insight 2017, 2, e83527. [CrossRef]

133. Wressnigg, N.; Hochreiter, R.; Zoihsl, O.; Fritzer, A.; Bezay, N.; Klingler, A.; Lingnau, K.; Schneider, M.; Lundberg, U.; Meinke, A.; et al. Single-shot live-attenuated chikungunya vaccine in healthy adults: A phase 1, randomised controlled trial. Lancet Infect. Dis. 2020, 20, 1193-1203. [CrossRef]

134. Carrau, L.; Rezelj, V.V.; Noval, M.G.; Levi, L.I.; Megrian, D.; Blanc, H.; Weger-Lucarelli, J.; Moratorio, G.; Stapleford, K.A.; Vignuzzi, M. Chikungunya Virus Vaccine Candidates with Decreased Mutational Robustness Are Attenuated In Vivo and Have Compromised Transmissibility. J. Virol. 2019, 93, e00775-19. [CrossRef]

135. Piper, A.; Ribeiro, M.; Smith, K.M.; Briggs, C.M.; Huitt, E.; Nanda, K.; Spears, C.J.; Quiles, M.; Cullen, J.; Thomas, M.E.; et al. Chikungunya virus host range $\mathrm{E} 2$ transmembrane deletion mutants induce protective immunity against challenge in C57BL/6J mice. J. Virol. 2013, 87, 6748-6757. [CrossRef] 
136. Gardner, C.L.; Hritz, J.; Sun, C.; Vanlandingham, D.L.; Song, T.Y.; Ghedin, E.; Higgs, S.; Klimstra, W.B.; Ryman, K.D. Deliberate attenuation of chikungunya virus by adaptation to heparan sulfate-dependent infectivity: A model for rational arboviral vaccine design. PLoS Negl. Trop. Dis. 2014, 8, e2719. [CrossRef]

137. Ludwig, G.V.; Turell, M.J.; Vogel, P.; Kondig, J.P.; Kell, W.K.; Smith, J.F.; Pratt, W.D. Comparative neurovirulence of attenuated and non-attenuated strains of Venezuelan equine encephalitis virus in mice. Am. J. Trop. Med. Hyg. 2001, 64, 49-55. [CrossRef]

138. Reed, D.S.; Lind, C.M.; Lackemeyer, M.G.; Sullivan, L.J.; Pratt, W.D.; Parker, M.D. Genetically engineered, live, attenuated vaccines protect nonhuman primates against aerosol challenge with a virulent IE strain of Venezuelan equine encephalitis virus. Vaccine 2005, 23, 3139-3147. [CrossRef]

139. Fine, D.L.; Roberts, B.A.; Terpening, S.J.; Mott, J.; Vasconcelos, D.; House, R.V. Neurovirulence evaluation of Venezuelan equine encephalitis (VEE) vaccine candidate V3526 in nonhuman primates. Vaccine 2008, 26, 3497-3506. [CrossRef]

140. Main, C.F.D.; Snow, D.; Mallory, R.M.; Helber, S.; Terpening, S.; Holley, H.P. Safety of an Attenuated Venezuelan Equine Encephalitis Virus (VEEV) Vaccine in Humans. In Proceedings of the America Infectious Diseases Society of America 2008 Annual Meeting, Washington, DC, USA, 25-28 October 2008.

141. Tretyakova, I.; Tibbens, A.; Jokinen, J.D.; Johnson, D.M.; Lukashevich, I.S.; Pushko, P. Novel DNA-launched Venezuelan equine encephalitis virus vaccine with rearranged genome. Vaccine 2019, 37, 3317-3325. [CrossRef]

142. Tretyakova, I.; Plante, K.S.; Rossi, S.L.; Lawrence, W.S.; Peel, J.E.; Gudjohnsen, S.; Wang, E.; Mirchandani, D.; Tibbens, A.; Lamichhane, T.N.; et al. Venezuelan equine encephalitis vaccine with rearranged genome resists reversion and protects nonhuman primates from viremia after aerosol challenge. Vaccine 2020, 38, 3378-3386. [CrossRef]

143. Trobaugh, D.W.; Sun, C.; Dunn, M.D.; Reed, D.S.; Klimstra, W.B. Rational design of a live-attenuated eastern equine encephalitis virus vaccine through informed mutation of virulence determinants. PLoS Pathog. 2019, 15, e1007584. [CrossRef] [PubMed]

144. Plante, K.; Wang, E.; Partidos, C.D.; Weger, J.; Gorchakov, R.; Tsetsarkin, K.; Borland, E.M.; Powers, A.M.; Seymour, R.; Stinchcomb, D.T.; et al. Novel chikungunya vaccine candidate with an IRES-based attenuation and host range alteration mechanism. PLoS Pathog. 2011, 7, e1002142. [CrossRef] [PubMed]

145. Roy, C.J.; Adams, A.P.; Wang, E.; Plante, K.; Gorchakov, R.; Seymour, R.L.; Vinet-Oliphant, H.; Weaver, S.C. Chikungunya vaccine candidate is highly attenuated and protects nonhuman primates against telemetrically monitored disease following a single dose. J. Infect. Dis. 2014, 209, 1891-1899. [CrossRef] [PubMed]

146. Partidos, C.D.; Paykel, J.; Weger, J.; Borland, E.M.; Powers, A.M.; Seymour, R.; Weaver, S.C.; Stinchcomb, D.T.; Osorio, J.E. Cross-protective immunity against o'nyong-nyong virus afforded by a novel recombinant chikungunya vaccine. Vaccine 2012, 30 , 4638-4643. [CrossRef]

147. Pandya, J.; Gorchakov, R.; Wang, E.; Leal, G.; Weaver, S.C. A vaccine candidate for eastern equine encephalitis virus based on IRES-mediated attenuation. Vaccine 2012, 30, 1276-1282. [CrossRef]

148. Rossi, S.L.; Guerbois, M.; Gorchakov, R.; Plante, K.S.; Forrester, N.L.; Weaver, S.C. IRES-based Venezuelan equine encephalitis vaccine candidate elicits protective immunity in mice. Virology 2013, 437, 81-88. [CrossRef]

149. Rossi, S.L.; Russell-Lodrigue, K.E.; Killeen, S.Z.; Wang, E.; Leal, G.; Bergren, N.A.; Vinet-Oliphant, H.; Weaver, S.C. IRESContaining VEEV Vaccine Protects Cynomolgus Macaques from IE Venezuelan Equine Encephalitis Virus Aerosol Challenge. PLoS Negl. Trop. Dis. 2015, 9, e0003797. [CrossRef]

150. Guerbois, M.; Volkova, E.; Forrester, N.L.; Rossi, S.L.; Frolov, I.; Weaver, S.C. IRES-driven expression of the capsid protein of the Venezuelan equine encephalitis virus TC-83 vaccine strain increases its attenuation and safety. PLoS Negl. Trop. Dis. 2013, 7, e2197. [CrossRef]

151. Mota, M.T.O.; Costa, V.V.; Sugimoto, M.A.; Guimaraes, G.F.; Queiroz, C.M., Jr.; Moreira, T.P.; de Sousa, C.D.; Santos, F.M.; Queiroz, V.F.; Passos, I.; et al. In-depth characterization of a novel live-attenuated Mayaro virus vaccine candidate using an immunocompetent mouse model of Mayaro disease. Sci. Rep. 2020, 10, 5306. [CrossRef]

152. Weise, W.J.; Hermance, M.E.; Forrester, N.; Adams, A.P.; Langsjoen, R.; Gorchakov, R.; Wang, E.; Alcorn, M.D.H.; Tsetsarkin, K.; Weaver, S.C. A novel live-attenuated vaccine candidate for mayaro Fever. PLoS Negl. Trop. Dis. 2014, 8, e2969. [CrossRef]

153. Tiwari, M.; Parida, M.; Santhosh, S.R.; Khan, M.; Dash, P.K.; Rao, P.V. Assessment of immunogenic potential of Vero adapted formalin inactivated vaccine derived from novel ECSA genotype of Chikungunya virus. Vaccine 2009, 27, 2513-2522. [CrossRef]

154. Kumar, M.; Sudeep, A.B.; Arankalle, V.A. Evaluation of recombinant E2 protein-based and whole-virus inactivated candidate vaccines against chikungunya virus. Vaccine 2012, 30, 6142-6149. [CrossRef]

155. Mohan, K. Phase-I Open Label, Dose-Escalation Clinical Trial to Evaluate the Safety, Tolerability and Immunogenicity of Chikungunya Vaccine in Healthy Adults of 18 to 50 Years Age: U.S National Library of Medicine. 2020. Available online: https: / / clinicaltrials.gov/ct2/show / NCT04603131 (accessed on 18 March 2021).

156. Pittman, P.R.; Liu, C.T.; Cannon, T.L.; Mangiafico, J.A.; Gibbs, P.H. Immune interference after sequential alphavirus vaccine vaccinations. Vaccine 2009, 27, 4879-4882. [CrossRef]

157. Maryam, K.-J.; Reisler, R.B.; Purcell, B.K.; Rivard, R.G.; Cardile, A.P.; Liggett, D.; Norris, S.; Pitttman, P.R. 2773. Safety and Immunogenicity Study of Eastern Equine Encephalitis Vaccine. Open Forum Infect. Dis. 2019, 6, 978-979. [CrossRef]

158. Rivard, R. Phase 2 Open-Label Safety and Immunogenicity Study of the Eastern Equine Encephalitis (EEE) Vaccine, Inactivated, Dried, TSI-GSD 104, Lot 2-1-89, in Healthy Adult Subjects at Risk of Exposure to Eastern Equine Encephalitis Virus: U.S. National Library of Medicine. 2016. Available online: https:/ / www.clinicaltrials.gov/ct2/show / NCT02654509 (accessed on 18 March 2021). 
159. Honnold, S.P.; Bakken, R.R.; Fisher, D.; Lind, C.M.; Cohen, J.W.; Eccleston, L.T.; Spurgers, K.B.; Maheshwari, R.K.; Glass, P.J. Second generation inactivated eastern equine encephalitis virus vaccine candidates protect mice against a lethal aerosol challenge. PLoS ONE 2014, 9, e104708. [CrossRef]

160. Martin, S.S.; Bakken, R.R.; Lind, C.M.; Garcia, P.; Jenkins, E.; Glass, P.J.; Parker, M.D.; Hart, M.K.; Fine, D.L. Evaluation of formalin inactivated V3526 virus with adjuvant as a next generation vaccine candidate for Venezuelan equine encephalitis virus. Vaccine 2010, 28, 3143-3151. [CrossRef]

161. Gupta, P.; Sharma, A.; Spurgers, K.B.; Bakken, R.R.; Eccleston, L.T.; Cohen, J.W.; Honnold, S.P.; Glass, P.J.; Maheshwari, R.K. 1,5-Iodonaphthyl azide-inactivated V3526 protects against aerosol challenge with virulent venezuelan equine encephalitis virus. Vaccine 2016, 34, 2762-2765. [CrossRef]

162. Fine, D.L.; Jenkins, E.; Martin, S.S.; Glass, P.; Parker, M.D.; Grimm, B. A multisystem approach for development and evaluation of inactivated vaccines for Venezuelan equine encephalitis virus (VEEV). J. Virol. Method. 2010, 163, 424-432. [CrossRef]

163. McCarty, J. A Phase 2 Parallel-Group, Randomized, Double-Blind Study to Assess the Safety and Immunogenicity of PXVX0317 (Chikungunya Virus Virus-Like Particle Vaccine [CHIKV-VLP], Unadjuvanted or Alum-adjuvanted): U.S. National Library of Medicine. 2018. Available online: https:/ / clinicaltrials.gov/ct2/show/NCT03483961 (accessed on 18 March 2021).

164. Metz, S.W.; Martina, B.E.; van den Doel, P.; Geertsema, C.; Osterhaus, A.D.; Vlak, J.M.; Pijlman, G.P. Chikungunya virus-like particles are more immunogenic in a lethal AG129 mouse model compared to glycoprotein E1 or E2 subunits. Vaccine 2013, 31, 6092-6096. [CrossRef]

165. Metz, S.W.; Gardner, J.; Geertsema, C.; Le, T.T.; Goh, L.; Vlak, J.M.; Pijlman, G.P. Effective chikungunya virus-like particle vaccine produced in insect cells. PLoS Negl. Trop. Dis. 2013, 7, e2124. [CrossRef] [PubMed]

166. Saraswat, S.; Athmaram, T.N.; Parida, M.; Agarwal, A.; Saha, A.; Dash, P.K. Expression and Characterization of Yeast Derived Chikungunya Virus Like Particles (CHIK-VLPs) and Its Evaluation as a Potential Vaccine Candidate. PLoS Negl. Trop. Dis. 2016, 10, e0004782. [CrossRef] [PubMed]

167. Goonewardena, S. A Phase 1 Dose Escalation Study to Assess the Safety and Immunogenicity of a Monovalent Virus-Like Particle (VLP) Venezuelan Equine Encephalitis Vaccine in Healthy Adults: U.S. National Library of Medicine. 2017. Available online: https: / / clinicaltrials.gov/ct2/show / NCT03776994 (accessed on 18 March 2021).

168. Ko, S.Y.; Akahata, W.; Yang, E.S.; Kong, W.P.; Burke, C.W.; Honnold, S.P.; Nichols, D.K.; Huang, Y.-J.S.; Schieber, G.L.; Carlton, K.; et al. A virus-like particle vaccine prevents equine encephalitis virus infection in nonhuman primates. Sci. Transl. Med. 2019, 11, 492. [CrossRef] [PubMed]

169. Ledgerwood, J.C.G. A Phase 1 Open Label, Dose-Escalation Clinical Trial to Evaluate the Safety and Immunogenicity of a Trivalent Virus-Like Particle (VLP) Encephalitis Vaccine, VRC-WEVVLP073-00-VP, in Healthy Adults: U.S. National Library of Medicine. 2019. Available online: https:/ / clinicaltrials.gov/ct2/show /NCT03879603 (accessed on 18 March 2021).

170. Riemenschneider, J.; Garrison, A.; Geisbert, J.; Jahrling, P.; Hevey, M.; Negley, D.; Schmaljohn, A.; Lee, J.; Hart, M.K.; Vanderzanden, L.; et al. Comparison of individual and combination DNA vaccines for B. anthracis, Ebola virus, Marburg virus and Venezuelan equine encephalitis virus. Vaccine 2003, 21, 4071-4080. [CrossRef]

171. Hart, M.K.; Pratt, W.; Panelo, F.; Tammariello, R.; Dertzbaugh, M. Venezuelan equine encephalitis virus vaccines induce mucosal IgA responses and protection from airborne infection in BALB/c, but not C3H/HeN mice. Vaccine 1997, 15, 363-369. [CrossRef]

172. Perkins, S.D.; O’Brien, L.M.; Phillpotts, R.J. Boosting with an adenovirus-based vaccine improves protective efficacy against Venezuelan equine encephalitis virus following DNA vaccination. Vaccine 2006, 24, 3440-3445. [CrossRef]

173. Dupuy, L.C.; Locher, C.P.; Paidhungat, M.; Richards, M.J.; Lind, C.M.; Bakken, R.; Parker, M.D.; Wahlen, R.G.; Schmaljohn, C.S. Directed molecular evolution improves the immunogenicity and protective efficacy of a Venezuelan equine encephalitis virus DNA vaccine. Vaccine 2009, 27, 4152-4160. [CrossRef]

174. Tretyakova, I.; Lukashevich, I.S.; Glass, P.; Wang, E.; Weaver, S.; Pushko, P. Novel vaccine against Venezuelan equine encephalitis combines advantages of DNA immunization and a live attenuated vaccine. Vaccine 2013, 31, 1019-1025. [CrossRef]

175. Gauci, P.J.; Wu, J.Q.; Rayner, G.A.; Barabe, N.D.; Nagata, L.P.; Proll, D.F. Identification of Western equine encephalitis virus structural proteins that confer protection after DNA vaccination. Clin. Vaccine Immunol. 2010, 17, 176-179. [CrossRef]

176. Muthumani, K.; Lankaraman, K.M.; Laddy, D.J.; Sundaram, S.G.; Chung, C.W.; Sako, E.; Wu, L.; Khan, A.; Sardesai, N.; Kim, J.J.; et al. Immunogenicity of novel consensus-based DNA vaccines against Chikungunya virus. Vaccine 2008, 26, 5128-5134. [CrossRef]

177. Bao, H.; Ramanathan, A.A.; Kawalakar, O.; Sundaram, S.G.; Tingey, C.; Bian, C.B.; Muruganandam, N.; Vijauachari, P.; Sardesai, N.Y.; Weiner, D.B.; et al. Nonstructural protein 2 (nsP2) of Chikungunya virus (CHIKV) enhances protective immunity mediated by a CHIKV envelope protein expressing DNA Vaccine. Viral Immunol. 2013, 26, 75-83. [CrossRef]

178. Mallilankaraman, K.; Shedlock, D.J.; Bao, H.; Kawalekar, O.U.; Fagone, P.; Ramanathan, A.A.; Ferraro, B.; Stabenow, J.; Vijayachari, P.; Sundaran, S.G.; et al. A DNA vaccine against chikungunya virus is protective in mice and induces neutralizing antibodies in mice and nonhuman primates. PLoS Negl. Trop. Dis. 2011, 5, e928. [CrossRef] [PubMed]

179. Dupuy, L.C.; Richards, M.J.; Livingston, B.D.; Hannaman, D.; Schmaljohn, C.S. A Multiagent Alphavirus DNA Vaccine Delivered by Intramuscular Electroporation Elicits Robust and Durable Virus-Specific Immune Responses in Mice and Rabbits and Completely Protects Mice against Lethal Venezuelan, Western, and Eastern Equine Encephalitis Virus Aerosol Challenges. J. Immunol. Res. 2018, 2018, 8521060. 
180. Choi, H.; Kudchodkar, S.B.; Reuschel, E.L.; Asija, K.; Borole, P.; Ho, M.; Wojtak, K.; Reed, C.; Ramos, S.; Bopp, N.E.; et al. Protective immunity by an engineered DNA vaccine for Mayaro virus. PLoS Negl. Trop. Dis. 2019, 13, e0007042. [CrossRef]

181. Tretyakova, I.; Hearn, J.; Wang, E.; Weaver, S.; Pushko, P. DNA vaccine initiates replication of live attenuated chikungunya virus in vitro and elicits protective immune response in mice. J. Infect. Dis. 2014, 209, 1882-1890. [CrossRef]

182. Muthumani, K.; Block, P.; Flingai, S.; Muruganantham, N.; Chaaithanya, I.K.; Tingey, C.; Wise, M.; Reuschel, E.L.; Chung, C.; Muthumani, A.; et al. Rapid and Long-Term Immunity Elicited by DNA-Encoded Antibody Prophylaxis and DNA Vaccination Against Chikungunya Virus. J. Infect. Dis. 2016, 214, 369-378. [CrossRef]

183. Szurgot, I.; Ljungberg, K.; Kummerer, B.M.; Liljestrom, P. Infectious RNA vaccine protects mice against chikungunya virus infection. Sci. Rep. 2020, 10, 21076. [CrossRef]

184. Dupuy, L.C.; Richards, M.J.; Ellefsen, B.; Chau, L.; Luxembourg, A.; Hannaman, D.; Livingston, B.D.; Schmaljohn, C.S. A DNA vaccine for venezuelan equine encephalitis virus delivered by intramuscular electroporation elicits high levels of neutralizing antibodies in multiple animal models and provides protective immunity to mice and nonhuman primates. Clin. Vaccine Immunol. 2011, 18, 707-716. [CrossRef]

185. Hannaman, D.; Dupuy, L.C.; Ellefsen, B.; Schmaljohn, C.S. A Phase 1 clinical trial of a DNA vaccine for Venezuelan equine encephalitis delivered by intramuscular or intradermal electroporation. Vaccine 2016, 34, 3607-3612. [CrossRef]

186. Nagata, L.P.; Hu, W.G.; Masri, S.A.; Rayner, G.A.; Schmaltz, F.L.; Das, D.; Wu, J.; Long, M.C.; Chan, C.; Proll, D.; et al. Efficacy of DNA vaccination against western equine encephalitis virus infection. Vaccine 2005, 23, 2280-2283. [CrossRef]

187. Phillips, A.T.; Schountz, T.; Toth, A.M.; Rico, A.B.; Jarvis, D.L.; Powers, A.M.; Olson, K.E. Liposome-antigen-nucleic acid complexes protect mice from lethal challenge with western and eastern equine encephalitis viruses. J. Virol. 2014, 88, 1771-1780. [CrossRef]

188. Shaw, C.; Panther, L.; August, A.; Zaks, T.; Smolenov, I.; Bart, S.; Watson, M. Safety and immunogenicity of a mRNA-based chikungunya vaccine in a phase 1 dose-ranging trial. Int. J. Infect. Dis. 2019, 79, 17. [CrossRef]

189. Kose, N.; Fox, J.M.; Sapparapu, G.; Bombardi, R.; Tennekoon, R.N.; de Silva, A.D.; Elbashir, S.M.; Theisen, M.A.; HumphrisNarayanan, E.; Ciaramella, G.; et al. A lipid-encapsulated mRNA encoding a potently neutralizing human monoclonal antibody protects against chikungunya infection. Sci. Immunol. 2019, 4, eaaw6647. [CrossRef] [PubMed]

190. Moderna, T.X. A Phase 1, Randomized, Placebo-Controlled, Dose Ranging Study to Evaluate the Safety, Tolerability, Pharmacokinetics, and Pharmacodynamics of mRNA-1944, Encoding for an Anti-Chikungunya Virus Monoclonal Antibody, in Healthy Adults: U.S. National Library of Medicine. 2019. Available online: https:/ / clinicaltrials.gov/ct2/show / NCT03829384 (accessed on 18 March 2021).

191. Metz, S.W.; Geertsema, C.; Martina, B.E.; Andrade, P.; Heldens, J.G.; van Oers, M.M.; Goldbach, R.W.; Vlak, J.M.; Pijlman, G.P. Functional processing and secretion of Chikungunya virus E1 and E2 glycoproteins in insect cells. Virol. J. 2011, 8, 353. [CrossRef] [PubMed]

192. Khan, M.; Dhanwani, R.; Rao, P.V.; Parida, M. Subunit vaccine formulations based on recombinant envelope proteins of Chikungunya virus elicit balanced Th1/Th2 response and virus-neutralizing antibodies in mice. Virus Res. 2012, 167, 236-246. [CrossRef]

193. Brandler, S.; Ruffie, C.; Combredet, C.; Brault, J.B.; Najburg, V.; Prevost, M.C.; Habel, A.; Tauber, E.; Despres, P.; Tangy, F. A recombinant measles vaccine expressing chikungunya virus-like particles is strongly immunogenic and protects mice from lethal challenge with chikungunya virus. Vaccine 2013, 31, 3718-3725. [CrossRef]

194. Gerke, C.; Frantz, P.N.; Ramsauer, K.; Tangy, F. Measles-vectored vaccine approaches against viral infections: A focus on Chikungunya. Expert Rev. Vaccines 2019, 18, 393-403. [CrossRef]

195. Rossi, S.L.; Comer, J.E.; Wang, E.; Azar, S.R.; Lawrence, W.S.; Plante, J.A.; Ramsauer, K.; Schrauf, S.; Weaver, S.C. Immunogenicity and Efficacy of a Measles Virus-Vectored Chikungunya Vaccine in Nonhuman Primates. J. Infect. Dis. 2019, 220, 735-742. [CrossRef]

196. Ramsauer, K.; Schwameis, M.; Firbas, C.; Mullner, M.; Putnak, R.J.; Thomas, S.J.; Despres, P.; Tauber, E.; Jilma, B.; Tangy, F. Immunogenicity, safety, and tolerability of a recombinant measles-virus-based chikungunya vaccine: A randomised, double-blind, placebo-controlled, active-comparator, first-in-man trial. Lancet Infect. Dis. 2015, 15, 519-527. [CrossRef]

197. Reisinger, E.C.; Tschismarov, R.; Beubler, E.; Wiedermann, U.; Firbas, C.; Loebermann, M.; Pfeiffer, A.; Muellner, M.; Tauber, E.; Ramsauer, L. Immunogenicity, safety, and tolerability of the measles-vectored chikungunya virus vaccine MV-CHIK: A doubleblind, randomised, placebo-controlled and active-controlled phase 2 trial. Lancet 2019, 392, 2718-2727. [CrossRef]

198. Wang, E.; Volkova, E.; Adams, A.P.; Forrester, N.; Xiao, S.Y.; Frolov, I.; Weaver, S.C. Chimeric alphavirus vaccine candidates for chikungunya. Vaccine 2008, 26, 5030-5039. [CrossRef]

199. Wang, E.; Kim, D.Y.; Weaver, S.C.; Frolov, I. Chimeric Chikungunya viruses are nonpathogenic in highly sensitive mouse models but efficiently induce a protective immune response. J. Virol. 2011, 85, 9249-9252. [CrossRef]

200. Wang, E.; Petrakova, O.; Adams, A.P.; Aguilar, P.V.; Kang, W.; Paessler, S.; Volk, S.M.; Frolov, I.; Weaver, S.C. Chimeric Sindbis/eastern equine encephalitis vaccine candidates are highly attenuated and immunogenic in mice. Vaccine 2007, 25, 7573-7581. [CrossRef]

201. Paessler, S.; Fayzulin, R.Z.; Anishchenko, M.; Greene, I.P.; Weaver, S.C.; Frolov, I. Recombinant sindbis/Venezuelan equine encephalitis virus is highly attenuated and immunogenic. J. Virol. 2003, 77, 9278-9286. [CrossRef] 
202. Paessler, S.; Ni, H.; Petrakova, O.; Fayzulin, R.Z.; Yun, N.; Anishchenko, M.; Weaver, S.C.; Frolov, I. Replication and clearance of Venezuelan equine encephalitis virus from the brains of animals vaccinated with chimeric SIN/VEE viruses. J. Virol. 2006, 80, 2784-2796. [CrossRef]

203. Atasheva, S.; Wang, E.; Adams, A.P.; Plante, K.S.; Ni, S.; Taylor, K.; Miller, M.E.; Frolov, I.; Weaver, S.C. Chimeric alphavirus vaccine candidates protect mice from intranasal challenge with western equine encephalitis virus. Vaccine 2009, 27, 4309-4319. [CrossRef]

204. Garcia-Arriaza, J.; Cepeda, V.; Hallengard, D.; Sorzano, C.O.; Kummerer, B.M.; Liljestrom, P.; Esteban, M. A novel poxvirus-based vaccine, MVA-CHIKV, is highly immunogenic and protects mice against chikungunya infection. J. Virol. 2014, 88, 3527-3547. [CrossRef]

205. Weger-Lucarelli, J.; Chu, H.; Aliota, M.T.; Partidos, C.D.; Osorio, J.E. A novel MVA vectored Chikungunya virus vaccine elicits protective immunity in mice. PLoS Negl. Trop. Dis. 2014, 8, e2970. [CrossRef]

206. Van den Doel, P.; Volz, A.; Roose, J.M.; Sewbalaksing, V.D.; Pijlman, G.P.; van Middelkoop, I.; Duiverman, V.; van de Wetering, E.; Sutter, G.; Osterhaus, A.D.M.E.; et al. Recombinant modified vaccinia virus Ankara expressing glycoprotein E2 of Chikungunya virus protects AG129 mice against lethal challenge. PLoS Negl. Trop. Dis. 2014, 8, e3101. [CrossRef]

207. Hu, W.G.; Steigerwald, R.; Kalla, M.; Volkmann, A.; Noll, D.; Nagata, L.P. Protective efficacy of monovalent and trivalent recombinant MVA-based vaccines against three encephalitic alphaviruses. Vaccine 2018, 36, 5194-5203. [CrossRef]

208. Wang, D.; Suhrbier, A.; Penn-Nicholson, A.; Woraratanadharm, J.; Gardner, J.; Luo, M.; Le, T.T.; Anraku, I.; Sakalian, M.; Einfeld, D.; et al. A complex adenovirus vaccine against chikungunya virus provides complete protection against viraemia and arthritis. Vaccine 2011, 29, 2803-2809. [CrossRef]

209. Lopez-Camacho, C.; Kim, Y.C.; Blight, J.; Lazaro Moreli, M.; Montoya-Diaz, E.; Huiskonen, J.T.; Kummerer, B.M.; Reyes-Sandoval, A. Assessment of Immunogenicity and Neutralisation Efficacy of Viral-Vectored Vaccines Against Chikungunya Virus. Viruses 2019, 11, 322. [CrossRef] [PubMed]

210. Kroon Campos, R.; Preciado-Llanes, L.; Azar, S.R.; Kim, Y.C.; Brandon, O.; Lopez-Camacho, C.; Reyes-Sandoval, A.; Rossi, S.L. Adenoviral-Vectored Mayaro and Chikungunya Virus Vaccine Candidates Afford Partial Cross-Protection From Lethal Challenge in A129 Mouse Model. Front. Immunol. 2020, 11, 591885. [CrossRef] [PubMed]

211. Campos, R.K.; Preciado-Llanes, L.; Azar, S.R.; Lopez-Camacho, C.; Reyes-Sandoval, A.; Rossi, S.L. A Single and Un-Adjuvanted Dose of a Chimpanzee Adenovirus-Vectored Vaccine against Chikungunya Virus Fully Protects Mice from Lethal Disease. Pathogens 2019, 8, 231. [CrossRef] [PubMed]

212. Hill, A.V. Safety and Immunogenicity of a Candidate CHIKV Vaccine (CHIK001): National Library of Medicine (U.S.). 2018. Available online: https:/ / clinicaltrials.gov/ct2/show / record/NCT03590392 (accessed on 18 March 2021).

213. Phillpotts, R.J.; O’Brien, L.; Appleton, R.E.; Carr, S.; Bennett, A. Intranasal immunisation with defective adenovirus serotype 5 expressing the Venezuelan equine encephalitis virus E2 glycoprotein protects against airborne challenge with virulent virus. Vaccine 2005, 23, 1615-1623. [CrossRef]

214. Perkins, S.D.; Williams, A.J.; O’Brien, L.M.; Laws, T.R.; Phillpotts, R.J. CpG used as an adjuvant for an adenovirus-based Venezuelan equine encephalitis virus vaccine increases the immune response to the vector, but not to the transgene product. Viral. Immunol. 2008, 21, 451-457. [CrossRef]

215. Wu, J.Q.; Barabe, N.D.; Chau, D.; Wong, C.; Rayner, G.R.; Hu, W.G.; Nagata, L.P. Complete protection of mice against a lethal dose challenge of western equine encephalitis virus after immunization with an adenovirus-vectored vaccine. Vaccine 2007, 25, 4368-4375. [CrossRef]

216. Swayze, R.D.; Bhogal, H.S.; Barabe, N.D.; McLaws, L.J.; Wu, J.Q. Envelope protein E1 as vaccine target for western equine encephalitis virus. Vaccine 2011, 29, 813-820. [CrossRef]

217. Chattopadhyay, A.; Wang, E.; Seymour, R.; Weaver, S.C.; Rose, J.K. A chimeric vesiculo/alphavirus is an effective alphavirus vaccine. J. Virol. 2013, 87, 395-402. [CrossRef]

218. Nasar, F.; Matassov, D.; Seymour, R.L.; Latham, T.; Gorchakov, R.V.; Nowak, R.M.; Leal, G.; Hamm, S.; Eldridge, J.H.; Tesh, R.B.; et al. Recombinant Isfahan Virus and Vesicular Stomatitis Virus Vaccine Vectors Provide Durable, Multivalent, Single-Dose Protection against Lethal Alphavirus Challenge. J. Virol. 2017, 91, e01729-16. [CrossRef]

219. Fierro, C. Phase 1 Vaccination Trial to Evaluate Safety, Tolerability and Immunogenicity of a Recombinant MVA-BN-WEV Vaccine in Healthy Adult Subjects: National Library of Medicine (U.S.). 2019. Available online: https://clinicaltrials.gov/ct2/show / study / NCT04131595 (accessed on 18 March 2021).

220. Erasmus, J.H.; Auguste, A.J.; Kaelber, J.T.; Luo, H.; Rossi, S.L.; Fenton, K.; Leal, G.; Kim, D.Y.; Chiu, W.; Wang, T.; et al. A chikungunya fever vaccine utilizing an insect-specific virus platform. Nat. Med. 2017, 23, 192-199. [CrossRef]

221. Lauring, A.S.; Jones, J.O.; Andino, R. Rationalizing the development of live attenuated virus vaccines. Nat. Biotechnol. 2010, 28, 573-579. [CrossRef]

222. Rueckert, C.; Guzman, C.A. Vaccines: From empirical development to rational design. PLoS Pathog. 2012, 8, e1003001. [CrossRef]

223. Coffey, L.L.; Beeharry, Y.; Borderia, A.V.; Blanc, H.; Vignuzzi, M. Arbovirus high fidelity variant loses fitness in mosquitoes and mice. Proc. Natl. Acad. Sci. USA 2011, 108, 16038-16043. [CrossRef]

224. Plotkin, S.A. Vaccines: Past, present and future. Nat. Med. 2005, 11, 5-11. [CrossRef]

225. Jang, Y.H.; Byun, Y.H.; Lee, K.H.; Park, E.S.; Lee, Y.H.; Lee, Y.J.; Lee, J.H.; Kim, K.H.; Seong, B.L. Host defense mechanism-based rational design of live vaccine. PLoS ONE 2013, 8, e75043. [CrossRef] 
226. Rossi, S.L.; Russell-Lodrigue, K.E.; Plante, K.S.; Bergren, N.A.; Gorchakov, R.; Roy, C.J.; Weaver, S.C. Rationally Attenuated Vaccines for Venezuelan Equine Encephalitis Protect Against Epidemic Strains with a Single Dose. Vaccines 2020, 8, 497. [CrossRef]

227. Yu, S.; Aaskov, J.G. Development of a candidate vaccine against Ross River virus infection. Vaccine 1994, 12, 1118-1124. [CrossRef]

228. Murphy, A.K.; Clennon, J.A.; Vazquez-Prokopec, G.; Jansen, C.C.; Frentiu, F.D.; Hafner, L.M.; Hu, W.B.; Devine, G.J. Spatial and temporal patterns of Ross River virus in south east Queensland, Australia: Identification of hot spots at the rural-urban interface. BMC Infect. Dis. 2020, 20, 722. [CrossRef]

229. Jansen, C.C.; Shivas, M.A.; May, F.J.; Pyke, A.T.; Onn, M.B.; Lodo, K.; Hall-Mendelin, S.; McMahon, J.L.; Montgomery, B.L.; Darbro, J.M.; et al. Epidemiologic, Entomologic, and Virologic Factors of the 2014-2015 Ross River Virus Outbreak, Queensland, Australia. Emerg. Infect. Dis. 2019, 25, 2243-2252. [CrossRef]

230. Pardi, N.; Hogan, M.J.; Porter, F.W.; Weissman, D. mRNA vaccines-A new era in vaccinology. Nat. Rev. Drug Discov. 2018, 17, 261-279. [CrossRef]

231. Hobernik, D.; Bros, M. DNA Vaccines-How Far From Clinical Use? Int. J. Mol. Sci. 2018, 19, 3605. [CrossRef] [PubMed]

232. Reichmuth, A.M.; Oberli, M.A.; Jaklenec, A.; Langer, R.; Blankschtein, D. mRNA vaccine delivery using lipid nanoparticles. Ther. Deliv. 2016, 7, 319-334. [CrossRef]

233. Schwendener, R.A. Liposomes as vaccine delivery systems: A review of the recent advances. Ther. Adv. Vaccin. 2014, 2, 159-182. [CrossRef] [PubMed]

234. Buschmann, M.D.; Carrasco, M.J.; Alishetty, S.; Paige, M.; Alameh, M.G.; Weissman, D. Nanomaterial Delivery Systems for mRNA Vaccines. Vaccines 2021, 9, 65. [CrossRef] [PubMed] 